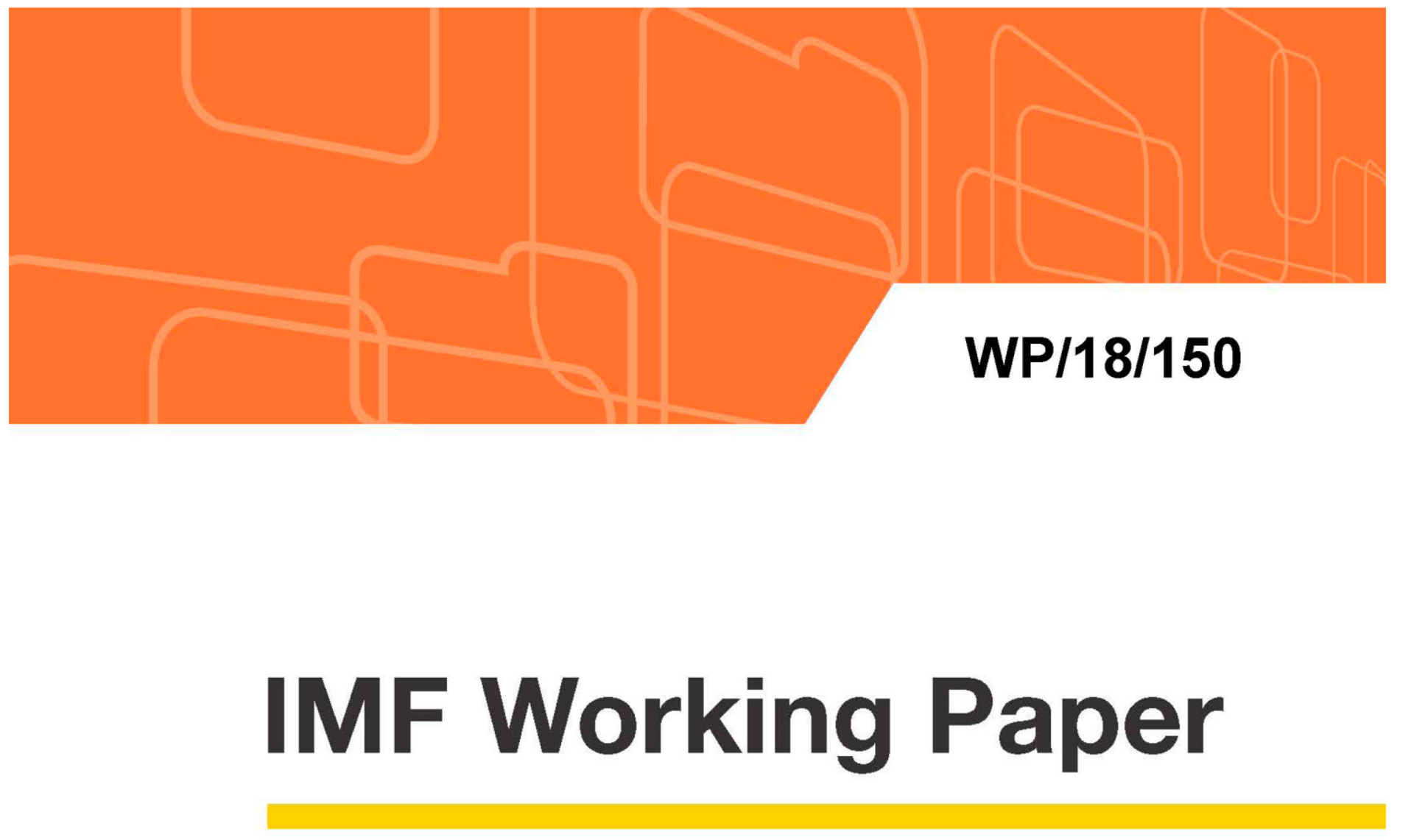

\title{
Drivers of Labor Force Participation in Advanced Economies: Macro and Micro Evidence
}

by Francesco Grigoli, Zsoka Koczan, and Petia Tapalova

IMF Working Papers describe research in progress by the author(s) and are published to elicit comments and to encourage debate. The views expressed in IMF Working Papers are those of the author(s) and do not necessarily represent the views of the IMF, its Executive Board, or IMF management.

I N T E R N A T I O N A L M O N E T A R Y F U N D 


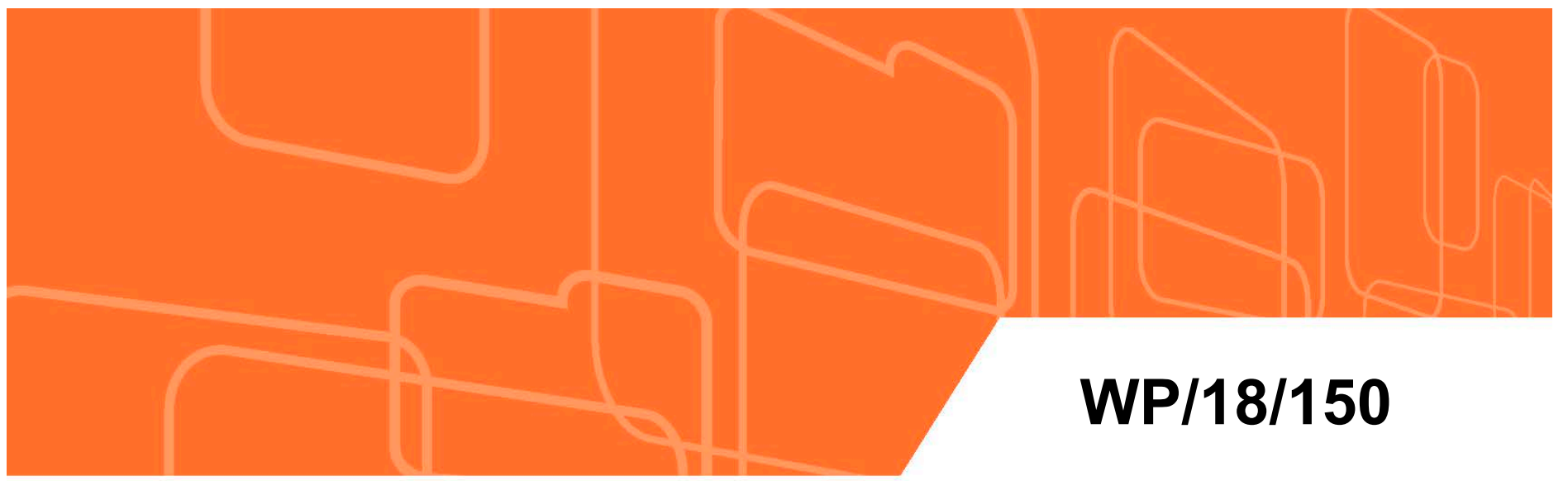

\section{IMF Working Paper}

\section{Drivers of Labor Force Participation in Advanced Economies: Macro and Micro Evidence}

by Francesco Grigoli, Zsoka Koczan, and Petia Tapalova

IMF Working Papers describe research in progress by the author(s) and are published to elicit comments and to encourage debate. The views expressed in IMF Working Papers are those of the author(s) and do not necessarily represent the views of the IMF, its Executive Board, or IMF management.

| N T E R N A T I O N A L M O N E T A R Y F U N D 


\title{
Drivers of Labor Force Participation in Advanced Economies: Macro and Micro Evidence*
}

\author{
Francesco Grigoli ${ }^{\dagger} \quad$ Zsoka Koczan ${ }^{\ddagger} \quad$ Petia Topalova ${ }^{\S}$
}

\begin{abstract}
Despite significant headwinds from population aging in most advanced economies (AEs), labor force participation rates show remarkably divergent trajectories both across countries and across different groups of workers. Participation increased sharply among prime-age women and, more recently, older workers, but fell among the young and prime-age men. This paper investigates the determinants of these trends using aggregate and individual-level data. We find that the bulk of the dramatic increase in the labor force attachment of prime-age women and older workers in the past three decades can be explained by changes in labor market policies and institutions, structural transformation, and gains in educational attainment. Technological advances such as automation, on the other hand, weighed on the labor supply of prime-age and older workers. In light of the dramatic demographic shifts expected in the coming decades in many AEs, our findings underscore the need to invest in education and training, reform the tax system, reduce early retirement incentives, improve the job-matching process, and help individuals combine family and work life in order to alleviate the pressures from aging on labor supply.
\end{abstract}

Keywords: labor force participation, policies, technology, routinization.

JEL Codes: J11, J21, O33.

*The views expressed in this Working Paper are those of the authors and do not necessarily represent those of the IMF or IMF policy. Working Papers describe research in progress by the authors and are published to elicit comments and to encourage debate. We thank, without implicating, Stephanie Aaronson, Oya Celasun, Romain Duval, Gian Maria Milesi-Ferretti, Davide Furceri, and Maury Obstfeld for their comments and suggestions. We are also grateful to Mitali Das, Romain Duval, and Davide Furceri for sharing their data on routinization and labor market polices. Benjamin Hilgenstock, Christopher Johns, and Jungjin Lee provided excellent research assistance.

${ }^{\dagger}$ International Monetary Fund, Research Department, fgrigoli@imf.org.

¥International Monetary Fund, Research Department, zkoczan@imf.org.

$\S$ International Monetary Fund, Research Department, ptopalova@imf.org. 


\section{Contents}

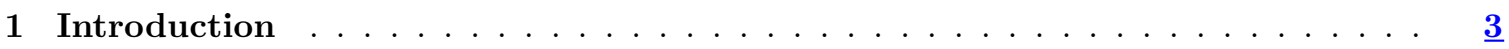

2 Patterns of Labor Force Participation $\ldots \ldots \ldots \ldots \ldots \ldots \ldots \ldots \ldots \ldots \ldots$

3 Drivers of Labor Force Participation: Conceptual Framework . . . . . . . . . $1 \underline{1}$

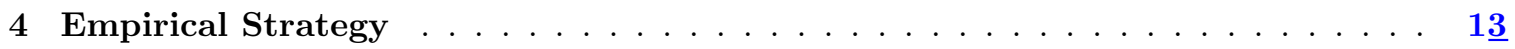

4.1 Aggregate Analysis . . . . . . . . . . . . . . . . . . . $\underline{13}$

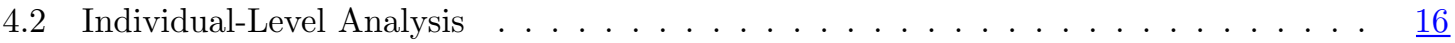

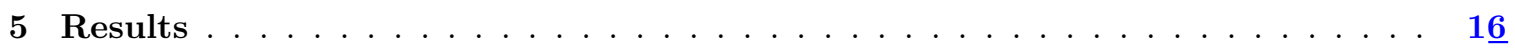

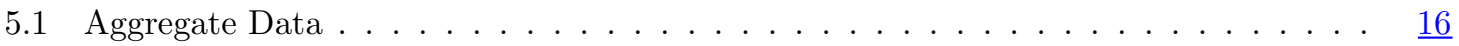

5.2 Individual-Level Data . . . . . . . . . . . . . . . . . . . $\underline{\underline{20}}$

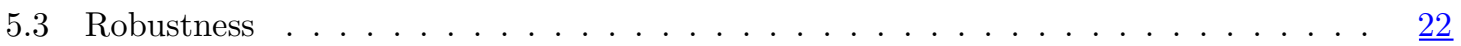

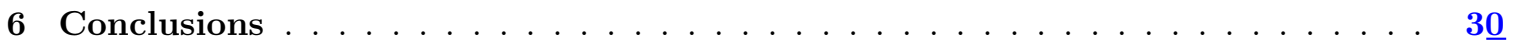

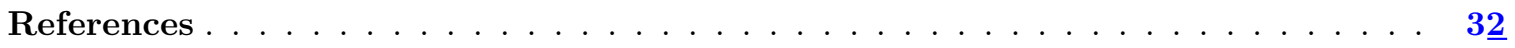

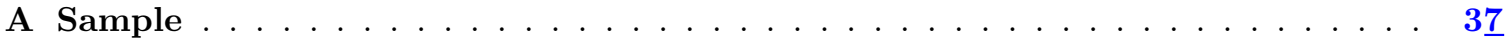

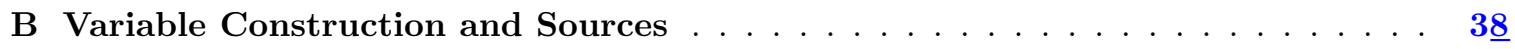

\section{List of Figures}

\begin{tabular}{|c|c|c|}
\hline & & - \\
\hline & Demographic Transition in AEs & \\
\hline & pation Rates by Gender and Age & \\
\hline & Labor Force Participation Rates in Selected Countries and Groups & \\
\hline & Participation Rates of Prime-Age Men and Women by Demographic & \\
\hline & 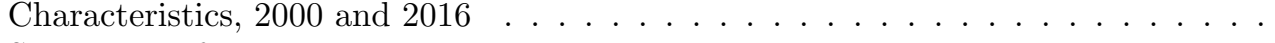 & \\
\hline & 000 and 2016 & \\
\hline & itinization & \\
\hline & Average Contributions to Changes in Participation Rates, 1995-2011 & \\
\hline
\end{tabular}

\section{List of Tables}

\begin{tabular}{|c|c|c|}
\hline & & Page \\
\hline 1 & Drivers of Labor Force Participation Rates & $\underline{18}$ \\
\hline 2 & Determinants of Being in the Labor Force & $\underline{21}$ \\
\hline 3 & Effects of Policies on the Relationship between Participation and Routinization & $\underline{2}$ \\
\hline 4 & Drivers of Youth (Ages 15-24) Labor Force Participation Rates, Robustness & $\leq$ \\
\hline 5 & Drivers of Prime-age Men (Ages 25-54) Labor Force Participation Rates, Robustnes & \\
\hline 6 & $\begin{array}{l}\text { Drivers of Prime-age Women }(\text { Ages } 25-54) \text { Labor Force Participation Rates, Ro- } \\
\text { bustness } \ldots \ldots \ldots \ldots \ldots \ldots\end{array}$ & \\
\hline 7 & $\begin{array}{l}\text { Drivers of Older Worker (Ages } 55 \text { and Over) Labor Force Participation Rates, Ro- } \\
\text { bustness } \ldots \ldots \ldots \ldots \ldots \ldots \ldots \ldots\end{array}$ & \\
\hline & Drivers of Aggregate Labor Force Participation Rates, Robustness & \\
\hline & eterminants of Being in the Labor Force, Robustness & \\
\hline
\end{tabular}




\section{Introduction}

Population growth in advanced economies (AEs) is slowing, life expectancy is rising, and the number of elderly is increasing steeply. As these trends gather pace, the United Nations projects that by the middle of this century, total population will be shrinking in almost half of AEs and individuals of what is currently considered working age will be supporting close to double the number of elderly that they do now (Figure 1, Panels 1 and 2). Unless more people participate in labor markets, aging could slow AEs' growth, and, in many cases, undermine the sustainability of their social security systems (Clements et al., 2015).

Figure 1: Demographic Transition in AEs
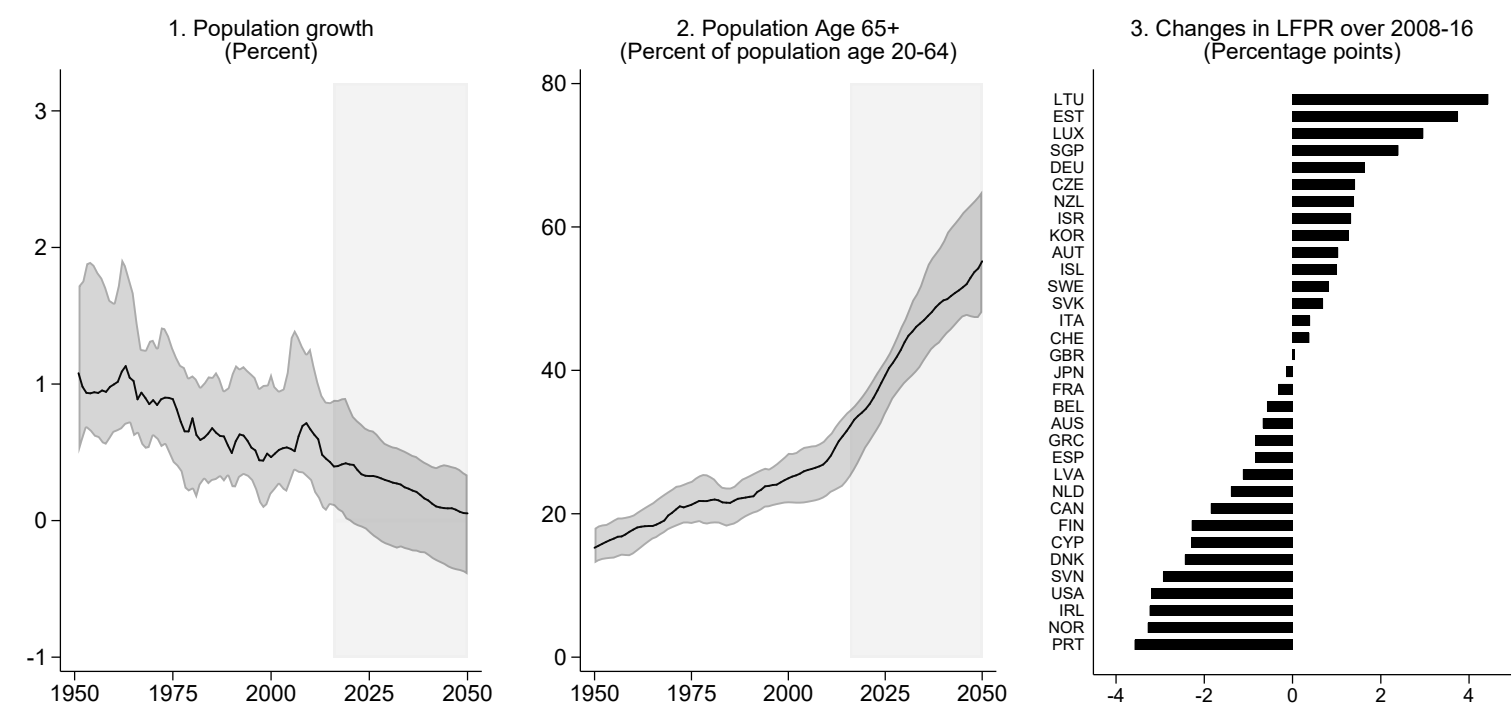

Source: Authors' calculations.

Notes: Based on a sample of 36 AEs. The black lines denote the averages, shaded dark grey areas denote the interquartile ranges for AEs, and light grey shaded areas indicate projections.

Even though population aging already exerts pressure on labor supply, aggregate labor force participation rates evolved quite differently across AEs. ${ }^{1}$ In half of these economies, the aggregate participation rate actually increased since the global financial crisis of a decade ago, which coincided with an acceleration of the demographic transition (Figure 1, Panel 3). Headline numbers also hide stark differences in the participation rates of different groups of workers. For example, prime-age male participation rates declined almost everywhere, while female participation rates increased. More recently, older workers became increasingly likely to remain in the labor force longer, while the participation of the young fell.

What underlies these diverging trajectories across countries and for different workers? Various forces are likely at play. Differences in the exact timing and pace of demographic transition could explain some of the divergence. However, the disparity in participation trends across specific groups of workers suggests a potentially important role for policies and institutions that influence the

\footnotetext{
${ }^{1}$ The labor force participation rate is the fraction of the adult population (ages 15 and over) either working or looking for work. In the rest of the paper, labor force participation and workforce attachment are used interchangeably.
} 
decisions of individuals to join, remain in, or reenter the labor force. Another factor could be differences in exposure and resilience to global forces such as technological advances and trade that may have depressed long-term demand for workers with certain skill sets (Acemoglu and Autor, 2011; Autor and Dorn, 2013; Goos et al., 2014; Autor et al., 2016; IMF, 2016b; IMF, 2017a). Identifying and ranking the key drivers of participation across population groups is necessary in designing policies that could enable those willing to work to do so and counteract the forces of aging.

Motivated by these considerations, in this paper, we investigate the key drivers of changes in aggregate participation rates and the attachment of various groups of workers to the labor force in a large sample of AEs using both aggregate data from the past three and a half decades and individual-level data since the beginning of the 2000s. We assess the relative importance of cyclical and structural changes in the economy, labor markets policies and institutions, and policies targeting specific groups of workers, namely women, older individuals, and migrants. Importantly, we examine whether shifts in the demand for certain types of labor due to the automation of routinizable tasks weighed on labor force participation of affected workers, using two complementary empirical approaches. First, we leverage the cross-country heterogeneity in the initial mix of employment across occupations to analyze whether declines in the relative price of investment led to greater reductions in participation rates in economies where a larger share of occupations were routinizable and hence subject to automation. Second, we rely on individual level data on current and past employment from 24 European countries during 2000-16 to estimate whether individuals whose occupation is more easily routinizable have a higher likelihood of being out of the labor force. We further examine whether labor market policies and other country characteristics can help attenuate the link between routinizability of occupation and subsequent labor force detachment.

Our findings suggest that policies and institutions, such as the tax benefit system, active labor market programs, and policies that encourage specific groups to participate, together with structural changes and gains in educational attainment, account for the bulk of the dramatic increase in the labor force attachment of prime-age women and older workers in the past three decades. On the other hand, technological advances - the automation of tasks where labor is easily substitutable by capital - weighed on the participation rates of most groups of workers. Encouragingly, we find that higher spending on active labor market programs and education is associated with a lower likelihood that an individual previously employed in a routinizable sector or occupation drops out of the labor force. This likelihood is also significantly lower in urban areas, pointing to the importance of accessing diverse pools of employers in minimizing the adjustment costs associated with technology-induced structural transformation.

Our study contributes to the vast literature on the determinants of labor force participation in three distinct ways. First, it considers a wider set of factors that shape individuals' decisions to work, including policies and institutions as well as the role of automation and structural transformation. While numerous studies leveraged cross-country heterogeneity to examine the role of policies on participation and employment outcomes of men and women in AEs (see Blanchard and Wolfers, 2000; Genre et al., 2005; Bertola et al., 2007; Bassanini and Duval, 2006; Bassanini and Duval, 2009; De Serres et al., 2012; Murtin et al., 2014; Gal and Theising, 2015), to the best of our knowledge, ours is the first study to estimate the effect of technological progress on participation in a cross-country setting. ${ }^{2}$ The role of migrant integration policies also received relatively little attention in the literature. Second, we combine the cross-country empirical findings

\footnotetext{
${ }^{2}$ For a discussion of the impact of automation and artificial intelligence on labor markets and inequality see for instance UN (2017), which emphasizes that this would likely involve job creation as well as job destruction, and that economic, legal, regulatory and socio-political factors will also affect whether the benefits of automating will outweigh the costs.
} 
with evidence from individual-level data to shed further light on the role of characteristics such as education and exposure to technological advances in workers' participation decisions. Finally, we re-visit earlier evidence on the effects of labor market policies on participation of different groups of workers (see Jaumotte, 2003; Genre et al., 2010; Blau and Kahn, 2013; Cipollone et al., 2013; Thévenon, 2013; Dao et al., 2014; Christiansen et al., 2016 for cross-country analyses of female labor force participation and employment and Blöndal and Scarpetta, 1999 and Duval, 2004 for cross-country analyses of retirement decisions) in a significantly larger estimation sample. The inclusion of more recent data allows us to re-assess the validity of previous findings in a period which witnessed significant shifts in the participation behavior of some workers, such as sizable increases in the participation of older workers, the decline in participation among the young, and the plateauing of female participation gains.

The rest of the paper is organized as follows. To set the stage, Section 2 describes the key patterns of labor force participation in AEs over the past three decades. Section 3 discusses various factors likely to affect labor force participation, while Section 4 outlines the empirical strategy. Section 5 discusses the results based on aggregate and individual-level data. Section 6 concludes.

\section{Patterns of Labor Force Participation}

An investigation into the long-term trends of aggregate labor force participation and the workforce attachment of individual groups of workers in AEs reveals several striking patterns. ${ }^{3}$ Over the past 30 years, the aggregate average labor force participation rate in AEs as a group barely changed (Figure 2, panel 1). However, the group aggregate masks significant differences in the experience of individual countries. While in a large share of AEs aggregate labor force participation in 2016 was within a couple of percentage points of what it was in 1985, several countries saw significant increases in the workforce attachment of their populations, with aggregate participation rates gaining more than five percentage points in countries such as Germany, Korea, Spain, and the Netherlands (Figure 2, panel 2). Moreover, the distribution of participation rates across AEs narrowed remarkably.

Even more striking is the divergence in the trends in labor force participation of different groups of workers (Figure 2, panels 3 and 8, and Figure 3). Across AEs, the share of women who are employed or actively looking for work increased by close to 10 percentage points over the past three decades. Gains in female participation were substantially larger in countries where women were historically less likely to be part of the workforce, a convergence that significantly narrowed the dispersion in women's participation across AEs since 1985. Conversely, participation rates of men, which are significantly higher and tend to be much more similar across countries, declined almost across the board. For the median AE, the participation rate among men was more than 6 percentage points lower in 2016 than in 1985. These divergent trends narrowed gender gaps.

Significant differences also exist in how participation rates evolved across individuals of different ages (Figure 2, panels 5-8). The young (between ages 15-24) are significantly less likely to be part of the labor force in 2016 than in 1985, with similar trends observed for men and women. To a significant extent, declining labor force attachment reflects the secular trend toward greater investment in human capital and higher school enrollment rates. ${ }^{4}$ In fact, the share of "idle" youth-

\footnotetext{
${ }^{3}$ The discussion of the long-term trends is based on the analysis of participation rates in 21 AEs for which data are available over 1985-2016, to ensure sample consistency. The patterns described are qualitatively identical if all AEs are included in the analysis.

${ }^{4}$ While some in this age group are in school and in the labor force, there is a significant association between
} 
Figure 2: Labor Force Participation Rates by Gender and Age

(Percent)

1. Total

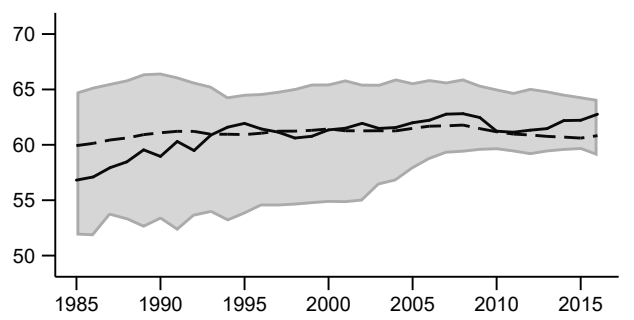

3. Men

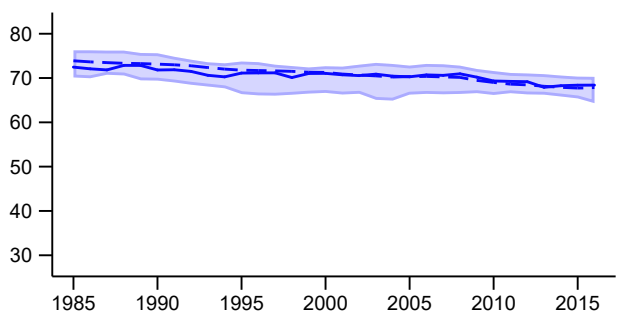

5. Age $15-24$

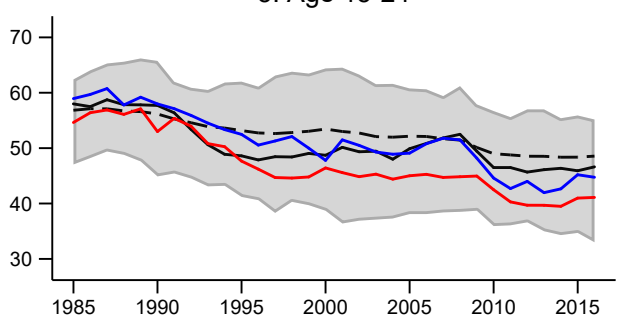

7. Age $55-64$

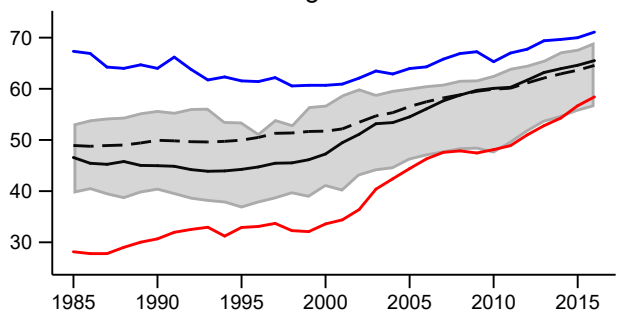

2. Distribution of chances

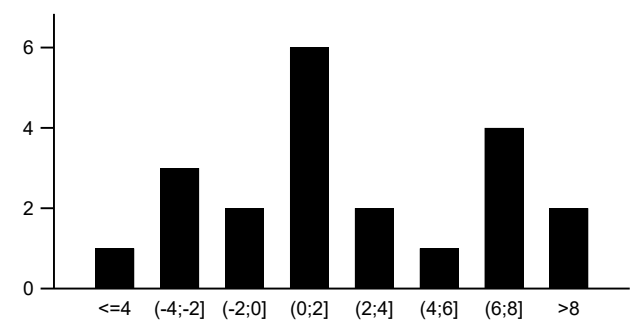

4. Women

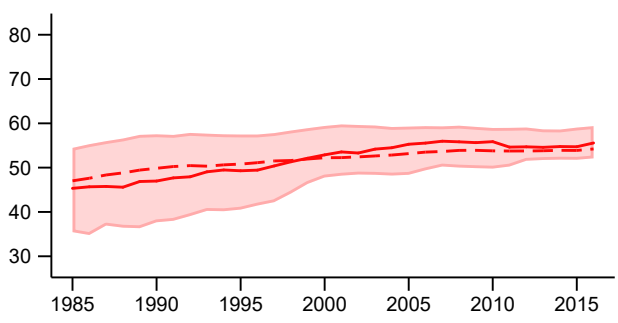

6. Age 25-54

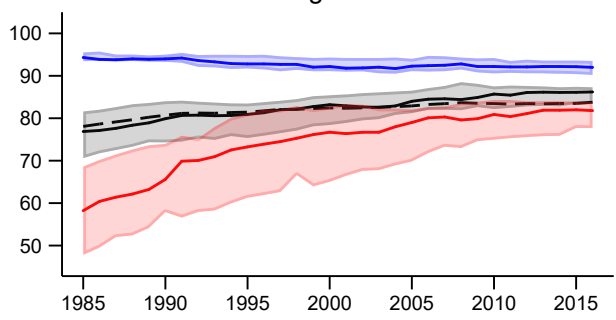

8. Age $65+$

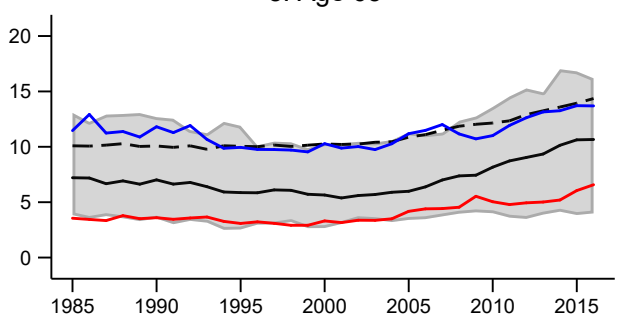

Source: Authors' calculations.

Notes: Solid lines denote medians, dotted lines denote population-weighted averages, and shaded areas denote interquartile ranges. In panels 5 to 8 , solid lines in blue and red denote medians for men and women, respectively.

increasing enrollment rates and declining participation rates across countries. 
Figure 3: Labor Force Participation Rates in Selected Countries and Groups

(Percent)
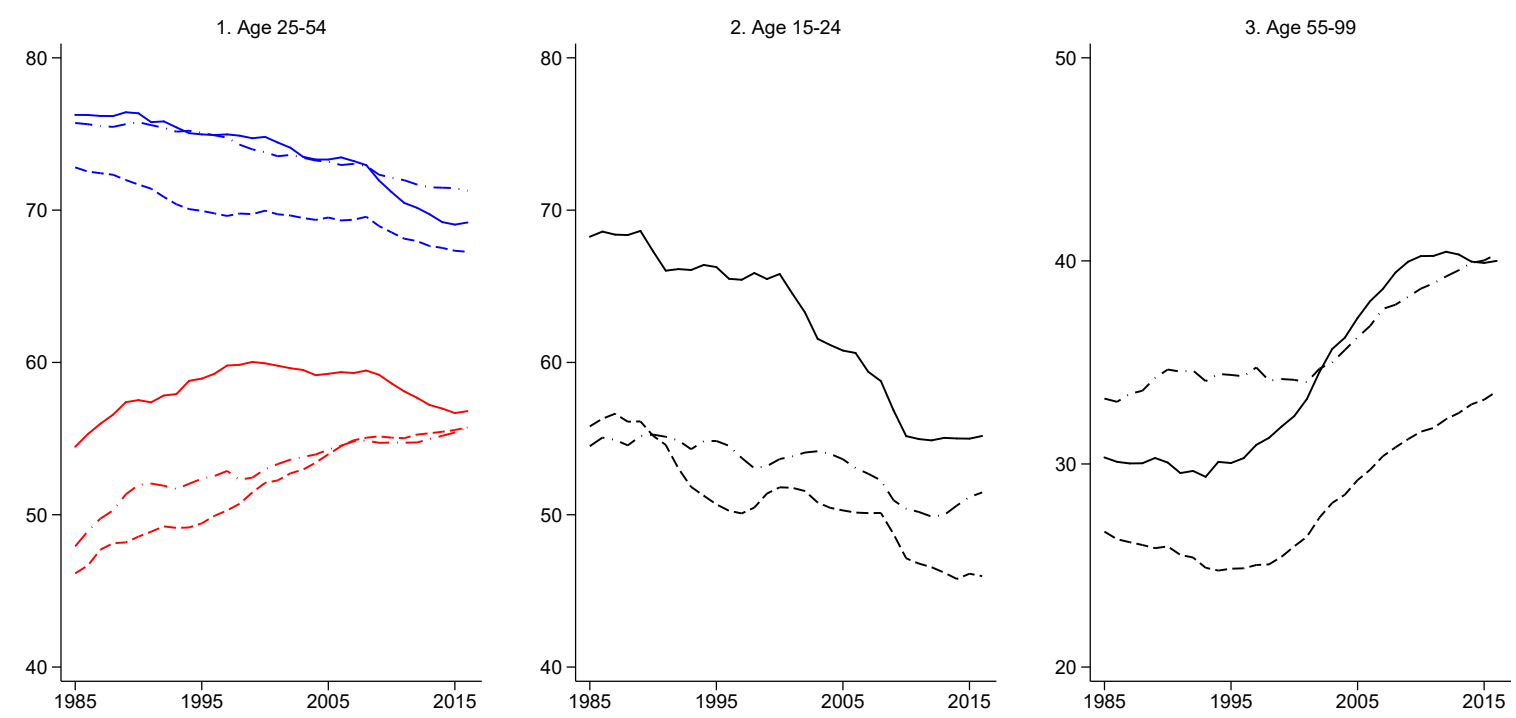

Source: Authors' calculations. Notes: Based on a sample of 33 AEs. The solid (dashed) [dash-dotted] lines denote averages for the United States (Europe) [other AEs]. Light red (blue) lines denote women (men). Other AEs include Australia, Canada, Japan, and Korea.

defined as those who are neither employed, unemployed, or enrolled in school - is quite small and has been stable since the early 2000s. ${ }^{5}$ Given the increase in the returns to schooling in many AEs, the decline in participation among the young could partly reflect an expected response to economic incentives (Krueger, 2017).

Participation rates of older men and women (aged over 55), on the other hand, increased significantly since the mid 1990s, following decades of steady decline. ${ }^{6}$ The increase is particularly pronounced for the 55-64 age group, but in the past decade, even individuals older than 65 remained in the labor force longer. For men, the observed increase in work force attachment at older ages likely reflects reduced retirement rates amid stable or slightly declining labor force participation at younger ages. For women, the observed increase can be associated with a growing pool of workers reaching those ages as well as changes in retirement behavior. The gains in participation among older workers should be viewed in the context of significantly longer lives. Life expectancy at birth increased by about seven years and at age 50 by over five years since 1985, prompting many countries to adopt policies to encourage longer working lives through later retirement.

Among prime-age workers, the most notable pattern is diverging trends of the labor force attachment of men versus women. The small decline in participation rates of prime-age men, which remains very high and varies little across countries, was more than offset by the dramatic entry of prime-age women in the labor force, leading to overall gains in the participation rates of prime-age

\footnotetext{
${ }^{5}$ The concept of idle youth is distinct from the NEETs (defined as those not in employment, education, or training) since the latter includes unemployed individuals. Youth unemployment is high and increased significantly after the global financial crisis in many AEs (Banerji et al., 2015).

${ }^{6}$ For a discussion of earlier trends in retirement, see Blöndal and Scarpetta (1999) and Gruber and Wise (2000).
} 
workers in most AEs. ${ }^{7}$ The United States is a notable exception to this overall pattern (Figure 3). Compared to other AEs, the decline in the prime-age male labor force participation rate was particularly steep in the past decade. ${ }^{8}$ While in most other AEs an increasing share of women joined the labor force, the prime-age female labor force participation rate in the United States plateaued in the late 1990s, and has been on a declining trend since the Global Financial Crisis.

Because labor force participation patterns could reflect significant shifts in the characteristics of the prime-age populations such as education, fertility, marriage, and immigration status, Figure 4 provides a more granular picture of the changes in the participation of subgroups since 2000 for most AEs (panels 1 and 5) and advanced European economies (panels 2 to 4 and 6 to 8). ${ }^{9}$ With the notable exception of relatively low-educated women, the rise in female labor force participation is remarkably widespread. Across Europe, single and married women, those with young children (below the age of 5), older children (below the age of 15 ) or no children, natives and immigrants are significantly more likely to be employed or looking for work in 2016 than in 2000. For prime-age men, the decline in participation was the deepest for those with the lowest educational attainment. Across all remaining groups, there was a small decline or stagnation for the median AE, suggesting that changes in population characteristics towards groups with lower participation, such as the falling share of married prime-age single men, were sizable. The United States stands out, with particularly deep declines for both women and men in the prime-age category across all levels of educational attainment.

Although the fall in labor force participation of prime-age men appears small sized for the median $\mathrm{AE}$, it is worrisome for several reasons. First, the decline is broad-based. Second, since prime-age men are still the largest segment of the labor force in AEs and have traditionally been the main income-earners for their families, even a small decline in their labor supply could have sizable macroeconomic consequences. ${ }^{10}$ Finally, detachment from the labor force during an individual's peak productive time is associated with lower happiness and life satisfaction for men (Winkelmann and Winkelmann, 1995; Knabe and Rätzel, 2011; Lucas et al., 2004; Krueger, 2017), poorer health and higher mortality (Eliason and Storrie, 2009; Gerdtham and Johannesson, 2003; Sullivan and Von Wachter, 2009), and depressed employment prospects (Arulampalam et al., 2000; Arulampalam et al., 2001).

Interesting insights can be gleaned from the reasons prime-age workers give for being out of the labor force. Figure 5 uses data from millions of workers surveyed across 26 countries in Europe to break down the non-participants into those who are students, retired, those who are not retired but never worked before, and those who were employed before but dropped out. It further breaks down the last group of nonparticipants based on the reason they reported for their detachment from the labor force.

\footnotetext{
${ }^{7}$ While it is possible that higher female participation allowed some men to drop out of the labor force, there is little evidence to that effect at the country level. Correlations between changes in prime-age female and male participation rates are, if anything, positive; and participation of married men declined by less than participation of single men (Figure 4, panel 2).

${ }^{8}$ The decline in labor force participation of prime-age men attracted considerable attention in the United States. See, for example, CEA (2016), Eberstadt (2016), Krause and Sawhill (2017), Krueger (2017), and Abraham and Kearney (2018).

${ }^{9}$ Due to data availability constraints, the analysis on participation by various demographic characteristics can be performed for a significantly shorter time span and a smaller sample of countries. It relies on individual-level data from the European Union Labour Force Survey to construct country-level participation rates for the subgroup of workers by marriage status, number of children, and immigration status, and on Eurostat data, complemented with data from national authorities, to build a picture of participation by educational attainment.

${ }^{10}$ In 2015, the labor force of the average AE had the following composition: 37 percent of workers were primeage men, 31 percent of workers were prime-age women, 11 percent of workers were aged 15-24 and 21 percent of workers were older than 55. The population of the average AE had the following composition: 20 percent were prime-age men, 20 percent were prime-age women, 12 percent were aged 15-24, 31 percent were older than 55 .
} 
Figure 4: Labor Force Participation Rates of Prime-Age Men and Women by Demographic Characteristics, 2000 and 2016

(Percent)
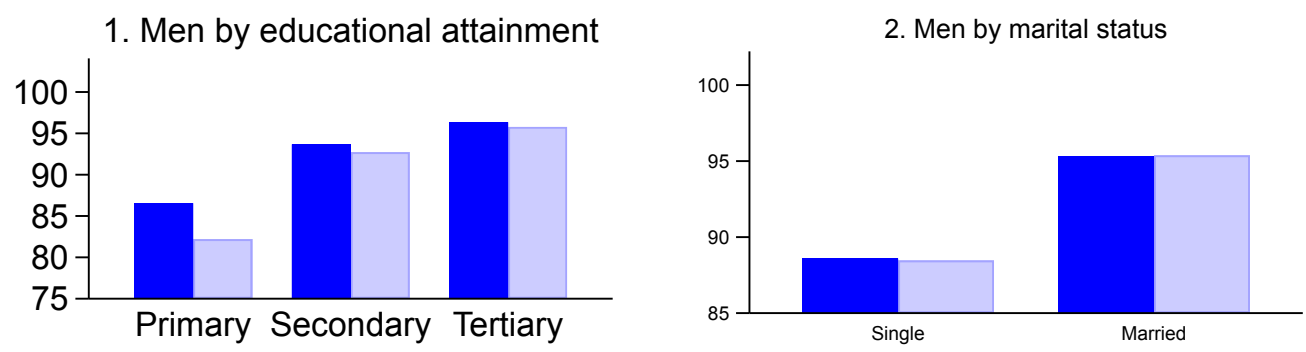

3. Men by family composition
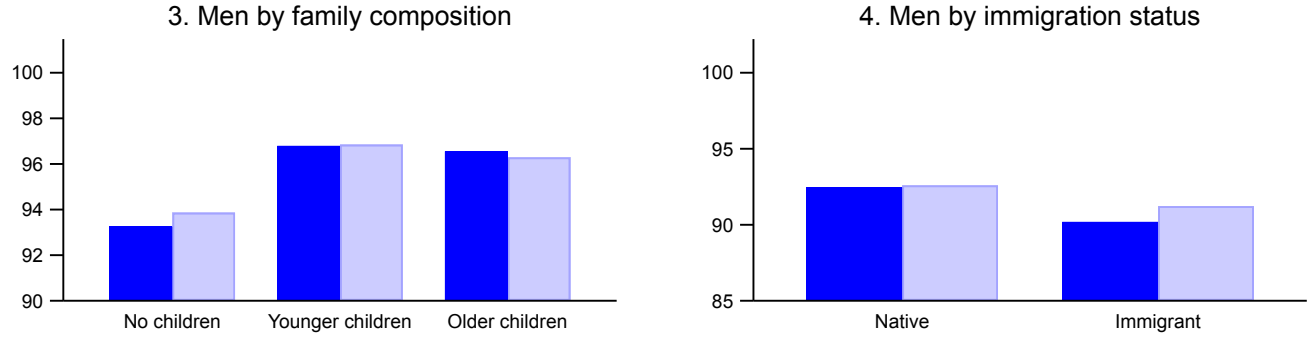

5. Women by educational attainment

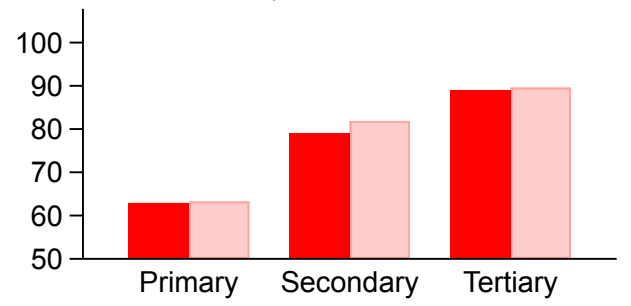

6. Women by marital status

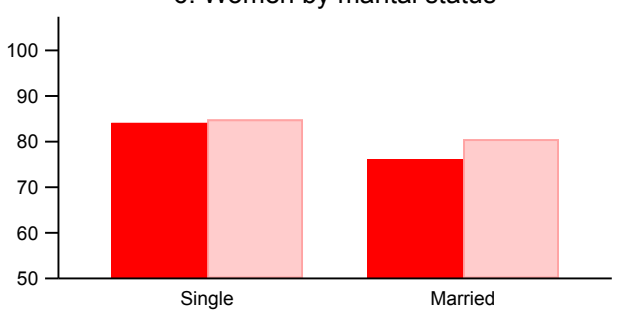

7. Women by family composition

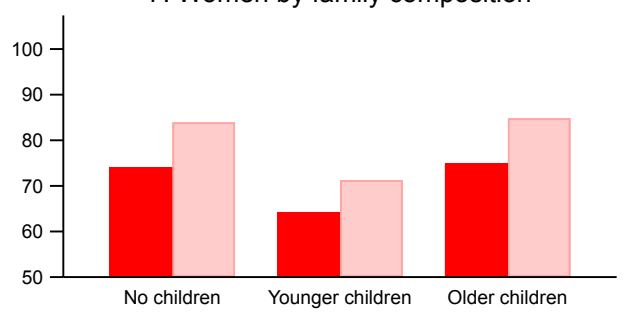

8. Women by immigration status

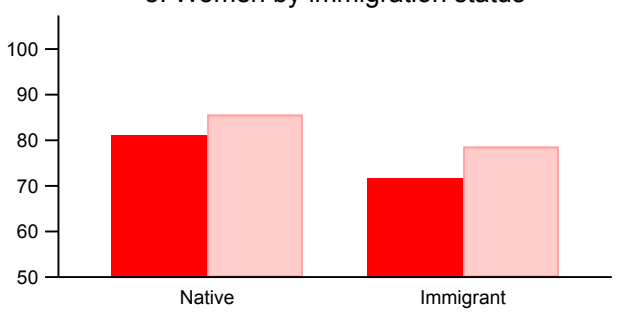

Source: Authors' calculations.

Notes: Dark blue and dark red denote year 2000, light blue and light red denote year 2016. In panels 4 and 8, dark bars show data for 2004 instead of 2000. Panels 1 and 5 are based on data from most AEs, while panels 2 to 4 and 6 to 8 are based on data from advanced European economies. Panels 3 and 7 report statistics for married individuals. Young children are those below the age of 5 ; older children are those age 5-15. Level of educational attainment is defined according to the International Standard Classification of Education (ISCED). Primary education 
Figure 5: Subgroups of the Inactive, 2000 and 2016

(Percent)

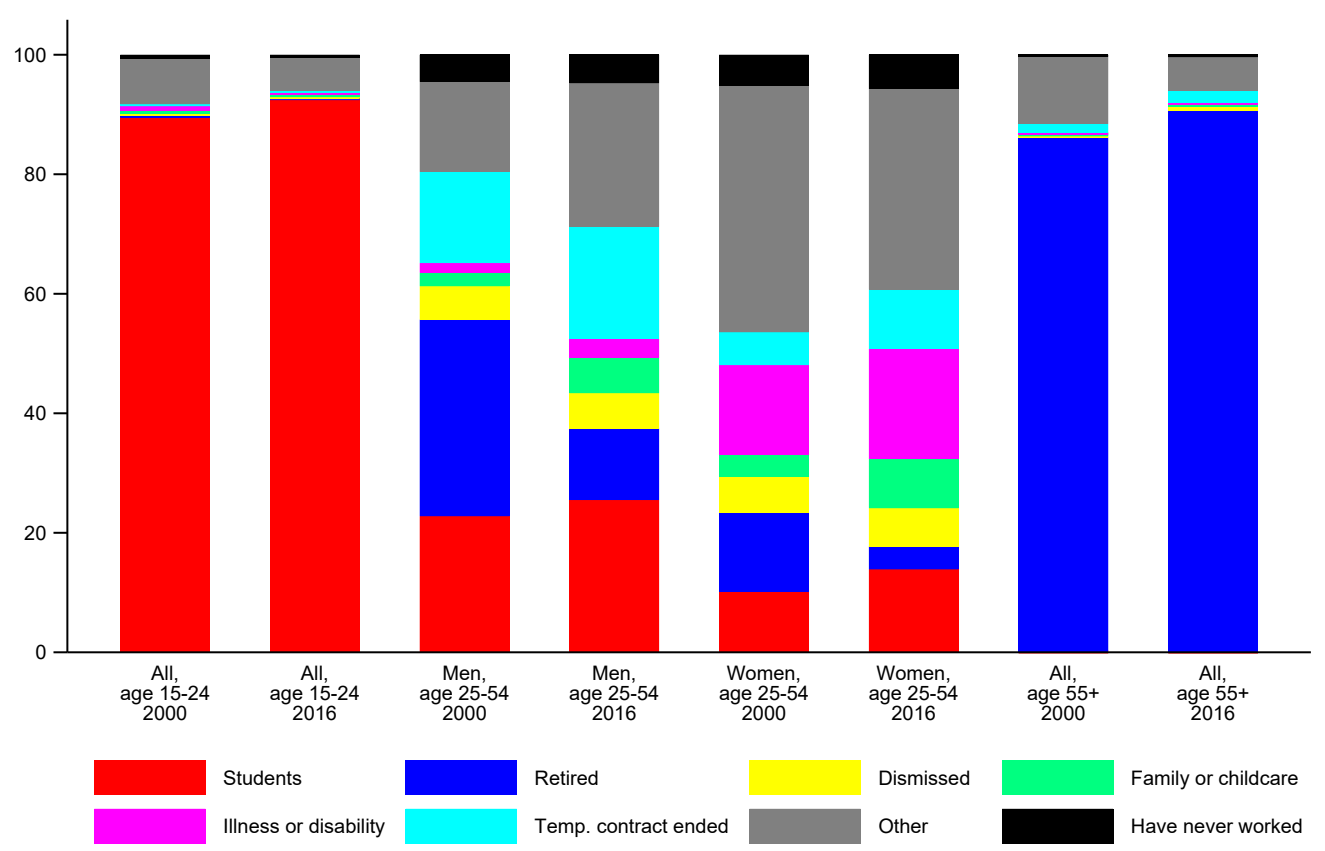

Source: Authors' calculations

Notes: Reported statistics are estimated from a random sample of 10,000 respondents per country per year. Retired includes early retirement.

Comparing the responses of prime-age men and prime-age women points to important gender differences in reasons for inactivity: for instance, women are still more likely to drop out of the labor force to look after children, while a higher fraction of men report illness and disability as reasons for not being employed. The responses also suggest that a non-negligible share of those who are out of the labor force may be "involuntarily inactive": they used to work but stopped due to economic (demand-side) factors, rather than a personal decision. Individuals reporting being dismissed from their last job as a reason for inactivity can be seen as a lower bound for this group. ${ }^{11}$

Involuntary nonparticipants drop out disproportionately from certain sectors of the economy (Figure 6, panel 1). Wholesale and retail trade, manufacturing, mining and quarrying, and utilities together account for over half of the involuntary inactive, even though less than one third of active workers (including employed and unemployed) are attached to these sectors. Excess involuntary inactivity-measured as the difference between the inactive individuals attached to a sector as a share of all nonparticipants and the active workers attached to the same sector as a share of the labor force - tends to be concentrated precisely in sectors that have a greater share of routine jobs that are vulnerable to automation (Figure 6, panel 2).

These stylized facts provide suggestive evidence of the potential harm of technological progress to participation rates of certain types of workers, an issue this paper examines in greater detail.

\footnotetext{
${ }^{11}$ In line with the stylized facts already discussed, comparing the years 2000 and 2016 suggests that over time the share of students increased, both among the young and the prime-age, while the share of those in (early) retirement among the prime-age fell, as did the share of those who never worked before among prime-age women and those over 55. Illness and disability became relatively more important over time as reason for non-participation.
} 
They also highlight potentially important income distributional consequences of involuntary inactivity. Displacement of workers tends to occur disproportionately among lower and middle-skilled occupations (Figure 6, panel 3) and vulnerability to routinization is especially pronounced in the middle and lower parts of the income distribution (Figure 6, panel 4).

\section{Drivers of Labor Force Participation: Conceptual Framework}

Numerous interrelated factors influence individuals' decisions to supply labor at various points in their life as they assess the expected return to market work relative to non-participation. Individual characteristics, such as gender, educational attainment, previous occupation, and household structure, would clearly shape that decision, as these determine potential earnings in the market place relative to the return to household work.

But labor market programs, institutions, and non-economic factors that govern individuals' prospects of finding (or retaining) a job and the relative benefit from working can also affect participation behavior. Some of these policies, such as the tax-benefits system, directly impact the incentives to supply labor, while others, such as wage setting institutions, can shape supply indirectly through reduced labor demand. For example, an increase in the labor tax wedge could reduce the incentives to work or seek employment, both by reducing net wages and suppressing labor demand by firms due to the increase in labor costs. However, the net effect of higher taxes on labor supply is ambiguous, as individuals may respond by working more to maintain their income. Conversely, active labor market programs that support jobseekers in finding vacancies may induce individuals to join the labor force and prevent those who temporarily lose employment from becoming permanently detached. Cultural attitudes toward people's role in society are also important, as they determine the disutility of market work, for example, from violating social norms or personally held beliefs (Fernández, 2013).

Policies tailored to address the challenges faced by specific workers can also influence their labor supply decisions. For example, provision of childcare, as well as family-friendly policies that bring more flexibility to work arrangements, make it easier for women to combine paid employment and motherhood and may discourage transitions out of the labor market. ${ }^{12}$ For older workers, financial incentives embedded in pension systems and other social transfer programs are important considerations in retirement decisions. With migration accounting for more than half of the growth in population in AEs in the past decade (see Koczan and Hilgenstock, 2018c), the ability of migrants to join the local labor force is becoming increasingly important for aggregate labor force participation rates. Policies that enable immigrants' swift integration into labor markets, such as provision of working rights, access to language and activation programs, and the like, can help them overcome their many disadvantages, including lack of information, poor access to informal networks, lack of transferable skills and qualifications, and low language proficiency (Aiyar et al., 2016).

Long-lasting changes in the demand for workers' skills could also influence individuals' workforce attachment. For example, the secular expansion of the services sector in many AEs (IMF, 2018) may have created significant employment opportunities for women, who are seen to have a comparative advantage in services, thus raising female participation. ${ }^{13}$ On the other hand, technolog-

\footnotetext{
${ }^{12}$ In a simple static labor supply model, a parent could choose to remain home and take care of an infant or a young child at the cost of their hourly wage (the foregone earnings) less the price of childcare services purchased outside the home. A more generous childcare subsidy would increase the parent's wage net of childcare cost, thus raising the opportunity cost of staying home and increasing labor supply on the extensive margin.

${ }^{13}$ See, for example, Ngai and Petrongolo (2017) for a model of structural transformation where relative gains in women's labor market outcomes are driven by changes towards the service-producing sector, as well as Olivetti
} 
Figure 6: The Role of Exposure to Routinization
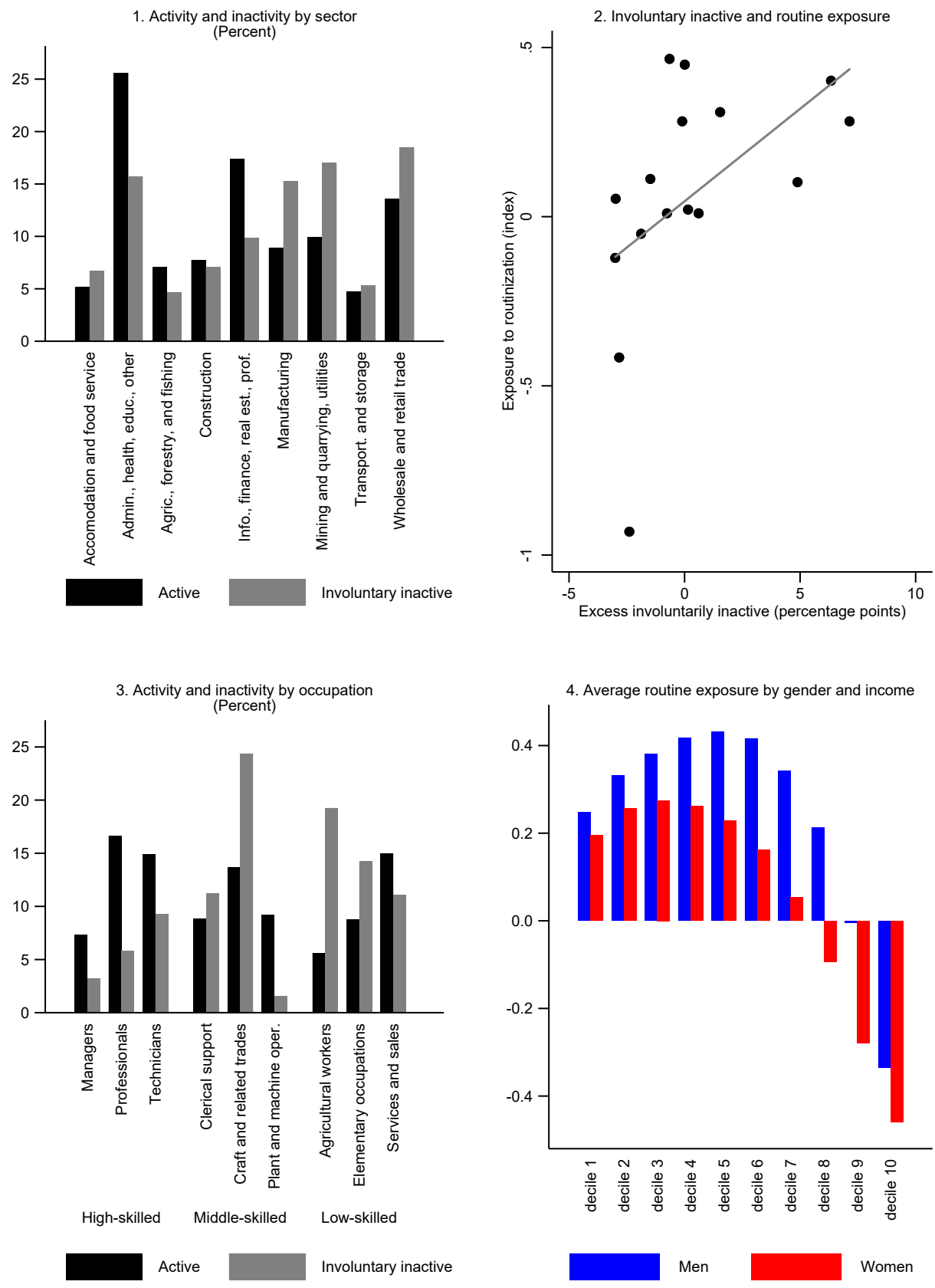

Source: Authors' calculations.

Notes: Reported statistics are estimated from a random sample of 10,000 respondents per country per year over the period 2000-16. In panels 1 and 3 , active includes employed and unemployed and involuntarily inactive refers to people inactive due to dismissal. For the inactive, sector or occupation are those of last employment. In panel 2, excess involuntarily inactive refers to the difference between the shares of active and involuntarily inactive.

and Petrongolo (2017) for empirical evidence on the role of the industrial structure in accounting for cross-country differences in gender outcomes. For a discussion of gender-based comparative advantage, see Feingold (1994), Galor and Weil (1996), Baron-Cohen et al. (2005), Christiansen et al. (2016), Rendall (2010), and Cortes et al. (2018), among others. 
ical progress that enabled routine jobs to be automated may have reduced the demand for lessskilled labor in AEs and made certain jobs obsolete. While these global developments benefit the economy as a whole, and create new opportunities in other sectors, workers may be unable to take advantage of these opportunities due to lack of relevant skills and training, preferences, hardship involved in relocating geographically, or a perceived inadequate return compared with their previous earnings.

Participation decisions are also shaped by even more short-lived changes in labor demand, such as those due to cyclical fluctuations (Elsby et al., 2015). The rise in unemployment during recessions may lead some workers to drop out of the labor force permanently. Diminished job prospects during recessions may also induce students to remain in school longer or lead parents (women especially) with young children to stay at home instead of seeking jobs. ${ }^{14}$

\section{Empirical Strategy}

We use two complementary empirical approaches to tease out the relative importance of the various drivers of labor force participation for different groups of workers. First, we estimate crosscountry panel regressions to disentangle the influence of labor policies, technology and other factors on the participation of different population segments. While the potential set of drivers is large, we focus on the variables most commonly discussed in the policy debate: the tax benefit system, activation policies, including those for migrants, wage-setting institutions, the role of structural changes, and exposure to routinization. The cross-country panel approach has the advantage of capturing the general equilibrium effects of various drivers, and quantifying their role in a unified framework. However, the measurement of policies is often imperfect and the identification of causal impacts can be problematic.

Second, alongside the analysis of macro data, we examine individual-level data from 24 European economies. This data allow for a deeper look at the effect of individual characteristics, including the extent to which (past) occupation can be automated, on workforce attachment, and the potential for policies to shape this relationship.

\subsection{Aggregate Analysis}

The aggregate analysis examines the historical relationship between the participation of individual groups of workers and potential drivers since 1980 across 23 economies, which were classified as AEs for the entire period. ${ }^{15}$ In line with the literature, we employ a reduced-form specification of labor force participation that relates the participation rate of specific groups of workers to factors that may affect the decision to supply labor. ${ }^{16}$ Our paper, however, expands considerably the

\footnotetext{
${ }^{14}$ Increasing evidence suggests that adverse initial labor market conditions can have substantial long-term effects on the earnings of college graduates. See, for example, Genda et al. (2010), Kahn (2010), and Oreopoulos et al. (2012).

${ }^{15}$ Appendix A reports the list of countries.

${ }^{16}$ The empirical approach in the paper is widely used in the cross-country literature on labor market. Blanchard and Wolfers (2000), Bertola et al. (2007), IMF (2003), Genre et al. (2005), Bassanini and Duval (2006), Bassanini and Duval (2009), De Serres et al. (2012), Murtin et al. (2014), and Gal and Theising (2015) examine determinants of employment and unemployment, among others. Jaumotte (2003), Genre et al. (2010), Blau and Kahn (2013), Cipollone et al. (2013), Thévenon (2013), Dao et al. (2014), Christiansen et al. (2016) look into the determinants of female labor force participation and employment, and Blöndal and Scarpetta (1999) and Duval (2004) investigate the effects of retirement decisions.
} 
temporal coverage of the analysis, capturing the last decade during which significant changes in participation occurred. Our focus on the effects of long-lasting shocks to labor demand, such as those stemming from technological advances, and on migrant integration policies is also new.

While the potential set of drivers of labor force participation is large, the analysis, guided by the conceptual framework described in Section 3, focuses on factors that can be measured relatively consistently across countries and over time, and are most commonly discussed in policy debates. ${ }^{17}$ In particular, we estimate the following equation:

$$
L F P_{i, t}^{g}=\beta^{X, g} X_{i, t}^{g}+\beta^{D, g} D_{i, t}+\beta^{G A P, g} G A P_{i, t-1}+\beta^{Z, g} Z_{i, t}+\pi_{i}^{g}+\tau_{t}^{g}+\epsilon_{i, t}^{g}
$$

where $L F P$ denotes the participation rate of worker group $g$ in country $i$ in year $t ; X$ represents the set of policies and institutions (some of which are specific to group $g$ ) including the labor tax wedge, the generosity of the unemployment benefits system, public expenditure on active labor market programs, the restrictiveness of migration policy, union density, the degree of coordination in wage setting, policies that help reconcile work inside and outside the household (i.e., public spending on childcare and education as a share of GDP, the proportion of employees working parttime, and the number of weeks of job-protected maternity leave), retirement incentives (proxied by the statutory retirement age and by the generosity of pension schemes). In the baseline specification, the generosity of pension schemes is measured as old-age and incapacity spending as percent of GDP, purged from fluctuations due to cyclical and demographic factors (share of the older population in different age groups and health status, proxied by life expectancy), that may mechanically generate a negative correlation with the labor force attachment of older workers. Conceptually more-appropriate measures of incentives for early retirement, such as the change in net pension wealth from an additional year in the labor force, or pension replacement rates, would severely restrict the sample, but are examined in robustness tests. In equation $1, D$ denotes a set factors that may shift the demand for worker group $g$, as the exposure to technological progress, the size of the service sector compared to the industrial one, and urbanization; GAP is the cyclical position of the economy proxied by the output gap; $Z$ includes other determinants of labor supply, as educational attainment. Finally, $\pi_{i}$ and $\tau_{t}$ are country- and time-fixed effects, respectively, which control for all differences across countries that are constant over time, and all shocks that are common to all countries.

We follow the literature in the construction of labor market policy variables and structural characteristics used in the analysis. ${ }^{18}$. Relative to previous studies, however, we employ two novel measures to capture (i) the impact of technological progress, and (ii) the role of migration policies. We measure exposure to technological progress as the interaction between the country's exposure to automation through its initial occupational mix and the relative price of investment as in Dao et al. (2017). To do so, we first compute the country's exposure to automation by assigning routinizability scores to each occupation following Autor and Dorn (2013), and aggregating these to a time-invariant country-level score using the initial employment distribution across occupations as weights. We then interact this country score with the average relative price of investment across AEs. The intuition behind this measure is that a decline in the relative price of capital goods,

\footnotetext{
${ }^{17}$ The vast theoretical literature on labor supply offers a large number of models with different assumptions, including about (i) the ability of consumers to transfer capital across periods and to consider more generally a lifecycle framework, (ii) the extent to which labor supply decisions are taken by the household rather than the individual worker, (iii) the role of uncertainty about future income, household composition, and/or health status, and (iv) the manner in which government programs affect the incentives to work (see Blundell and MaCurdy, 1999, for a review). Developing a macroeconomic theory of labor supply encompassing all these features for different groups of workers is beyond the scope of this paper.

${ }^{18}$ Appendix $\mathrm{B}$ discusses the construction of the variables in detail
} 
driven by global technological progress, would induce firms to substitute labor for capital. However, the labor market consequences of this process would be larger in countries where a larger fraction of workers have occupations in which labor can be easily substituted by capital, such as occupations in which many tasks performed by workers are routine and can be automated.

We also construct a new measure to capture policies supportive of migrants' integration in labor markets. Using the DEMIG POLICY database maintained by the International Migration institute, we focus on major changes in policies guiding the post-entry rights or other aspects of migrants' integration (see also De Resende, 2014). These changes are cumulated starting in 1980 to construct an index of the restrictiveness of migration policy for each country, with a higher value denoting more restrictive policies.

As discussed previously, we use a simple cross-country panel framework to estimate the sensitivity of labor force participation of various groups of workers to the set of potential drivers. The groups comprise young workers (ages 15-24), prime-age men (25-54), prime-age women (25-54), and older workers (ages 55 and over); an additional equation is estimated for a group encompassing all workers of ages 15 and over. Results from panel unit root tests suggest that the time series of labor force participation rates for different age groups are trend stationary. Limited data availability for some of the explanatory variables also precludes from employing a dynamic specification, which, in the presence of country-fixed effects, would return biased estimates (Nickell, 1981). Some of the evidently endogenous variables, such as the output gap and trade openness, are included in the specification with a one-year lag. Given the complex correlation structure of the error term with dependence across countries, autocorrelation due to the slow-moving nature of the dependent variable, and heteroskedasticity, we correct the standard errors using the Driscoll and Kraay (1998) method to make statistical inferences. ${ }^{19}$

To quantify the role played by each of the explanatory variables, we calculate the contributions from each regressor to changes in participation of group $g$ between year $t$ and $t^{\prime}$ as:

$$
C_{i, t, t^{\prime}}^{S, g}=\widehat{\beta}^{S, g}\left(S_{i, t^{\prime}}^{g}-S_{i, t}^{g}\right)
$$

with $S=[X, D, G A P, Z]$ and where $C_{i, t, t^{\prime}}^{S, g}$ is the contribution of variable $S$.

It is important to emphasize from the outset that, in this paper, we seek to identify patterns and correlations rather than to establish causality between various policies, structural, and individual characteristics on the one hand and labor force participation on the other. Changes in national labor market policies and institutions may reflect the evolution of societal and cultural attitudes toward work that influence observed trends in labor supply beyond their impact on policies. For example, the evolution of social norms toward more egalitarian gender roles may induce both family legislation and higher female labor force participation. Female labor supply shifts may also create political support for more family-friendly policies, leading simultaneously to higher female employment and greater parental leave rights (Olivetti and Petrongolo 2017). Yet, by providing a rich description of the cross-national and overtime patterns of labor force participation and its association with a broad set of drivers, the analysis aims to offer valuable guidance on potential areas for policy action.

\footnotetext{
${ }^{19}$ Lagrange Multiplier tests point to the existence of serial correlation and the modified Wald test for group-wise heteroskedasticity indicates the presence of heteroscedasticity in the specifications for all population groups. Also, the Pesaran test and Frees test reject the null hypothesis of cross-sectional independence.
} 


\subsection{Individual-Level Analysis}

We complement the cross-country analysis by examining evidence on labor force participation decisions from millions of individuals in Europe. The use of micro data offers important advantages relative to the cross-country analysis discussed so far: it allows for a deeper exploration of individual and household-level determinants of participation, it also mitigates the endogeneity bias arising from omitted variables and reverse causality in regressions relying on aggregate data, and it allows zooming in on the impact of technology and the extent to which policies can help offset its effect on individuals' decision to drop out of the labor force. ${ }^{20}$

The analysis relies on the European Labour Force Survey for 24 AEs during 2000-16. ${ }^{21}$. Due to the extremely large size of the survey, we draw a random sample of 10,000 individuals per country per year, which forms the basis of our empirical investigation. We then estimate logit models of the following form:

$$
\Phi\left(S_{j}=1\right)=\beta^{C} C_{i}+\beta^{H} H_{j}+\beta^{R} R_{j}+\pi_{c}+v_{r}+\tau_{t}+\epsilon_{j}
$$

where $\Phi$ is the probability function; $S$ is a dummy variable for whether the individual $j$ is in or out of the labor force; $C$ includes a set of individual characteristics such as age, gender (for the age 55 and over group), whether the individual was born in the country or abroad, whether they live in an urban or rural area, and their highest level of completed education (up to lower secondary, upper secondary or tertiary education); $H$ includes measures of family composition, such as number of children, number of other employed adults in the household, and whether the individual lives in a household of a single adult without children (the baseline category), a single adult with children, and a couple without or with children; $R$ is the routinization score of an individual's current occupation (if currently employed) or last occupation (if currently unemployed or inactive); $\pi_{c}, v_{r}$, and $\tau_{t}$ are country-, region-, and year-fixed effects. We cluster standard errors at the country-year level.

\section{Results}

\subsection{Aggregate Data}

The results in Table 1 indicate that education, cyclical and long-lasting shifts in labor demand, and labor market policies are strongly associated with participation rates. However, there are significant differences in the strength of association of workforce attachment to these factors across groups of workers.

In line with economic theory, education is a powerful predictor of labor force participation. An increase in the share of workers with secondary and especially tertiary education is associated with significantly higher participation, particularly for prime-age women and older workers. Higher education is also positively associated with participation of prime-age men, but to a smaller degree,

\footnotetext{
${ }^{20}$ Some of the variables explored when looking at individuals (including choices about educational attainment, marriage, and fertility) are still simultaneous with decisions about participating in the labor force.

${ }^{21}$ Appendix A reports the list of countries
} 
in line with the much smaller variability in their participation rates, as shown in Figure $4 .^{22}$

For most groups of workers, participation rates depend on the state of the business cycle. As expected, the association is significantly higher for those more marginally attached to the workforce, such as the young and women. The results also confirm that structural transformation that may shift the demand for certain types of workers affects their labor market involvement. A relative increase in service sectors employment is typically followed by the entry of prime-age women into the labor force, while urbanization brings gains in the participation of all groups, potentially by exposing them to a larger set of job opportunities.

Conversely, while technological change can benefit the economy as a whole, and create new opportunities in other sectors, it may not be fully benign from the point of view of some workers. A decline in the relative price of investment is associated with lower participation rates in countries where the initial occupation mix is tilted toward routine-task occupations, highlighting the difficulties of workers displaced by automation in finding alternative employment (see also Koczan and Hilgenstock, 2018a, and Koczan and Hilgenstock, 2018b for sub-national evidence on the United States and Europe). This finding is consistent with the role of technological progress, along with varying exposure to routine occupations, in the decline in the labor share in AEs documented in IMF (2017b) and Dao et al. (2017), and the sizable employment losses in the United States' local labor markets with greater exposure to robots as documented in Acemoglu and Restrepo (2017).

Participation rates are also responsive to labor market programs and institutions. In particular:

- The tax-benefit system has a robust relationship with participation rates. Higher labor tax wedges and more generous unemployment benefits are associated with lower labor force attachment for most groups of workers, in line with findings in the cross-country literature on their effect on employment (see, for example, Gal and Theising, 2015, and references therein). The negative relationship between participation rates and the generosity of unemployment benefits, measured as the gross benefit replacement rate, is consistent with (1) the positive correlation found in cross-country data between generosity of unemployment benefits and unemployment levels, which could depress participation through a discouragement effects, and (2) the fact that in many countries the unemployment insurance system provides a path to early retirement for older workers.

- Policies specifically geared toward improving the job-matching process are generally associated with stronger participation rates.

- Higher public spending on active labor market programs tends to raise the share of young and prime-age women working or seeking employment.

- The analysis also indicates that policies that encourage the integration of migrants can help boost prime-age workers' participation, with more pronounced effects on women. The positive association likely reflects the success of these policies in narrowing the sizable participation gaps between native and immigrant workers, which are especially wide for women (see Koczan and Hilgenstock, 2018c). However, other channels are possible. A more migrant-friendly policy stance may bring in more immigrants. Although migrants have a lower propensity to work than natives when they arrive, they are more likely to be prime-age than the native population and may boost aggregate participation rates through compositional shifts. Several recent studies also emphasize the complementarity of migrants' skills to those of the native population, which helps

\footnotetext{
${ }^{22}$ The negative association between labor force participation and the share of population with partial or completed tertiary education in ages 15-24 likely reflects that they are still in school.
} 
Table 1: Drivers of Labor Force Participation Rates

\begin{tabular}{|c|c|c|c|c|c|}
\hline & $\begin{array}{c}\text { All, } \\
\text { ages } 15-24 \\
(1)\end{array}$ & $\begin{array}{c}\text { Men, } \\
\text { ages } 25-54 \\
(2)\end{array}$ & $\begin{array}{l}\text { Women, } \\
\text { ages } 25-54 \\
(3)\end{array}$ & $\begin{array}{c}\text { All, } \\
\text { ages } 55+ \\
(4)\end{array}$ & $\begin{array}{c}\text { All, } \\
\text { ages } 15+ \\
\text { (5) }\end{array}$ \\
\hline Lag of Output Gap & $\begin{array}{c}0.360^{* * *} \\
(0.112)\end{array}$ & $\begin{array}{c}0.072^{* * *} \\
(0.020)\end{array}$ & $\begin{array}{l}0.170^{*} \\
(0.092)\end{array}$ & $\begin{array}{l}-0.006 \\
(0.068)\end{array}$ & $\begin{array}{c}0.183^{* * *} \\
(0.044)\end{array}$ \\
\hline Routinization*Relative Price of Investment & $\begin{array}{c}0.303 \\
(0.299)\end{array}$ & $\begin{array}{c}0.302^{* * *} \\
(0.048)\end{array}$ & $\begin{array}{c}1.793^{* * *} \\
(0.206)\end{array}$ & $\begin{array}{l}0.505^{*} \\
(0.288)\end{array}$ & $\begin{array}{c}0.536^{* * * *} \\
(0.175)\end{array}$ \\
\hline Lag of Trade Openness & $\begin{array}{c}0.059^{* * *} \\
(0.022)\end{array}$ & $\begin{array}{l}-0.005 \\
(0.005)\end{array}$ & $\begin{array}{c}0.010 \\
(0.014)\end{array}$ & $\begin{array}{c}-0.059^{* * * *} \\
(0.009)\end{array}$ & $\begin{array}{l}0.012^{*} \\
(0.007)\end{array}$ \\
\hline Relative Service Employment & $\begin{array}{l}-0.002 \\
(0.010)\end{array}$ & $\begin{array}{l}-0.002 \\
(0.002)\end{array}$ & $\begin{array}{c}0.015^{* * *} \\
(0.005)\end{array}$ & $\begin{array}{c}0.009 \\
(0.006)\end{array}$ & $\begin{array}{c}0.010^{* *} \\
(0.004)\end{array}$ \\
\hline Urbanization & $\begin{array}{c}0.668^{* * * *} \\
(0.142)\end{array}$ & $\begin{array}{c}0.101 \text { *** } \\
(0.019)\end{array}$ & $\begin{array}{c}0.355 * * * \\
(0.071)\end{array}$ & $\begin{array}{c}0.194 \\
(0.115)\end{array}$ & $\begin{array}{c}0.249^{* * * *} \\
(0.047)\end{array}$ \\
\hline Education (\% Secondary) & $\begin{array}{l}-0.050 \\
(0.042)\end{array}$ & $\begin{array}{c}0.019 * * * \\
(0.007)\end{array}$ & $\begin{array}{c}0.211 * * * \\
(0.017)\end{array}$ & $\begin{array}{l}0.038^{*} \\
(0.021)\end{array}$ & $\begin{array}{c}0.063^{* * *} \\
(0.017)\end{array}$ \\
\hline Education (\% Tertiary) & $\begin{array}{c}-0.275^{* * *} \\
(0.057)\end{array}$ & $\begin{array}{c}0.019 \\
(0.015)\end{array}$ & $\begin{array}{c}0.332 * * * \\
(0.030)\end{array}$ & $\begin{array}{c}0.389^{* * *} \\
(0.050)\end{array}$ & $\begin{array}{c}0.135^{* * * *} \\
(0.031)\end{array}$ \\
\hline Tax wedge & $\begin{array}{l}-0.103 \\
(0.064)\end{array}$ & $\begin{array}{l}-0.002 \\
(0.015)\end{array}$ & $\begin{array}{c}-0.129^{* * *} \\
(0.029)\end{array}$ & $\begin{array}{c}-0.263^{* * * *} \\
(0.037)\end{array}$ & $\begin{array}{c}-0.240^{* * * *} \\
(0.026)\end{array}$ \\
\hline Unemployment Replacement Ratio & $\begin{array}{l}-0.002 \\
(0.068)\end{array}$ & $\begin{array}{c}-0.041^{* * *} \\
(0.007)\end{array}$ & $\begin{array}{l}-0.035 \\
(0.033)\end{array}$ & $\begin{array}{l}-0.081 \\
(0.050)\end{array}$ & $\begin{array}{c}-0.078^{* * *} \\
(0.025)\end{array}$ \\
\hline Public Spending on ALMP & $\begin{array}{c}0.041^{* * *} \\
(0.014)\end{array}$ & $\begin{array}{c}0.005 \\
(0.005)\end{array}$ & $\begin{array}{c}0.039^{* * *} \\
(0.006)\end{array}$ & $\begin{array}{c}-0.025^{* *} \\
(0.009)\end{array}$ & $\begin{array}{c}0.031^{* * *} \\
(0.007)\end{array}$ \\
\hline Restrictiveness of Migrant Integration Policies & $\begin{array}{c}0.491^{* * *} \\
(0.098)\end{array}$ & $\begin{array}{c}-0.047^{* *} \\
(0.020)\end{array}$ & $\begin{array}{c}-0.462^{* * *} \\
(0.049)\end{array}$ & $\begin{array}{c}0.056 \\
(0.088)\end{array}$ & $\begin{array}{c}-0.207^{* * * *} \\
(0.049)\end{array}$ \\
\hline Union Density & $\begin{array}{l}-0.009 \\
(0.068)\end{array}$ & $\begin{array}{l}-0.001 \\
(0.011)\end{array}$ & $\begin{array}{c}0.153^{* * *} \\
(0.044)\end{array}$ & $\begin{array}{c}-0.115^{* * *} \\
(0.032)\end{array}$ & $\begin{array}{l}-0.015 \\
(0.025)\end{array}$ \\
\hline Coordination of Wage-Setting & $\begin{array}{c}1.104^{* * *} * \\
(0.245)\end{array}$ & $\begin{array}{c}0.131^{* *} \\
(0.063)\end{array}$ & $\begin{array}{c}0.701 * * * \\
(0.219)\end{array}$ & $\begin{array}{c}0.040 \\
(0.222)\end{array}$ & $\begin{array}{c}0.256^{* *} \\
(0.120)\end{array}$ \\
\hline Public Spending on Early Childhood Education and Care & & & $\begin{array}{c}3.708^{* * *} \\
(1.210)\end{array}$ & & \\
\hline Share of Part-Time Employment & & & $\begin{array}{c}0.946^{* * *} \\
(0.118)\end{array}$ & & \\
\hline Job-Protected Maternity Leave & & & $\begin{array}{c}0.025^{* * *} \\
(0.006)\end{array}$ & & \\
\hline Statutory Retirement Age & & & & $\begin{array}{c}0.661^{* * *} \\
(0.174)\end{array}$ & \\
\hline Public Spending on Old-Age Pension & & & & $\begin{array}{c}-0.750^{* * *} \\
(0.154)\end{array}$ & \\
\hline Public Spending on Incapacity & & & & $\begin{array}{l}-0.421 \\
(0.562)\end{array}$ & \\
\hline Observations & 571 & 571 & 489 & 568 & 570 \\
\hline Countries & 23 & 23 & 23 & 23 & 23 \\
\hline$R$-squared & 0.515 & 0.606 & 0.887 & 0.686 & 0.578 \\
\hline
\end{tabular}

boost natives' labor market outcomes, especially women's. ${ }^{23}$ The negative association between more friendly migration policies and youth labor force participation is not surprising since integration measures include providing migrants with access to education and training, which could lead to a higher inflow of foreign students and increase school enrollment of non-native youth.

- Women's willingness to work or seek employment is significantly influenced by policies that help them reconcile work inside and outside the household. Consistent with the findings of a large body of literature, we find that better access to childcare, longer maternity leave, and greater flexibility in work arrangements are associated with higher female labor force participation. ${ }^{24}$

\footnotetext{
${ }^{23}$ See, for example, Carrasco et al. (2008), D'Amuri and Peri (2014), Cattaneo et al. (2015), Aiyar et al. (2016), Foged and Peri (2016), and IMF (2016a).

${ }^{24}$ See Olivetti and Petrongolo (2017) and the references therein for a recent review of the evidence on the eco-
} 
- For older workers, incentives for retirement have a powerful effect on labor force attachment. ${ }^{25}$ Raising the statutory retirement age is associated with delayed exit from the labor market, while greater pension scheme generosity seems to encourage early retirement. The latter finding is robust to using conceptually more appropriate, but less widely available, measures of incentives for early retirement, such as the implicit tax on continued work, or pension replacement rates.

- Finally, the evidence on the role of wage-setting institutions - unionization, and the degree of wage bargaining coordination - is mixed. Higher coordination of wage setting is associated with greater labor force participation for most groups of workers, consistent with the idea that more coordinated bargaining systems may lead to wage moderation during downturns as unions internalize the potentially detrimental effects that excessive wage pressure may have on overall employment (Soskice, 1990, and Bassanini and Duval, 2006). However, the correlation between unionization and participation is less robust to changes in the sample, or the inclusion of other policies.

Putting policies, education, structural shifts, and technology together, we examine the contributions of these factors to changes in participation rates between 1995 and 2011 in Figure 7. Supportive policies and educational gains were key factors behind the dramatic increase in the participation of prime-age women and older workers, with structural transformation contributing positively as well. On the other hand, technological advances weighed on participation for all groups of workers, except the young.

For the young (and to a certain extent prime-age male workers), a significant share of the decline in participation is attributed to a common component across AEs, captured by the time effects in the regressions. This common factor could reflect the common influence of global forces, such as technological progress or globalization, concurrent changes in policies, structural transformations, or other factors that may affect labor supply decisions across the advanced world, including changing returns to education, rising life expectancy, or common scars from the global financial crisis. For older workers, the latter might have delayed retirement, as captured in the positive common component, due to suppressed returns on retirement savings as global interest rates fell, losses in financial wealth, and potentially higher indebtedness.

Comparing how the various factors relate to participation changes across geographic regions can shed light on the reasons behind their (sometimes) divergent trends. For example, the analysis reveals that the striking difference in the participation trend for women in the United States relative to the average European trend can be attributed to the more supportive policy changes in Europe as well as the larger gains in educational attainment among prime-age European women. The factors behind the rise in participation among older workers are very similar across all regions: gains in education, structural transformation, and the introduction of policies that discourage early retirement. ${ }^{26}$ However, the reason why prime-age men and the youth in the United States became so much more disconnected from the labor market than their European counterparts remains somewhat puzzling, as evidenced by the sizable residual in the decomposition of the change. Many hypotheses have been put forth for this decline that are specific to the United States and can, consequently, not be evaluated in a cross-country setting, such as the role of rising disability

nomic consequences of family policies, as well as, Jaumotte (2003), Genre et al. (2010), Blau and Kahn (2013), Cipollone et al. (2013), Thévenon (2013), Dao et al. (2014), Christiansen et al. (2016), and IMF (2016b).

${ }^{25}$ See Blundell et al. (2016) and for a review of the literature on retirement incentives and labor supply, as well as $\operatorname{IMF}(2016 \mathrm{~b})$.

${ }^{26}$ See, among others, Blau and Goodstein (2010) and Hurd and Rohwedder (2011) for evidence from the United States, and Börsch-Supan and Ferrari (2017) for evidence from Germany. 
and opioid usage, higher incarceration rates, and improved leisure technology. ${ }^{27,} 28$

\subsection{Individual-Level Data}

We report the results of the logit estimations of equation (3) in Table 2. In line with the aggregate findings, the analysis points to large and significant effects of higher education on participation. Having tertiary education roughly doubles the odds of being active in the labor market relative to having up to lower secondary education, with somewhat larger effects for women. Living in urban areas also increases participation rates, likely on account of having access to a more diverse labor market with more opportunities. Natives are also more likely to participate than immigrants.

Family composition has a considerable influence on the decision of an individual to work or seek employment, although there are large gender differences. Relative to the baseline category of being the only adult in a household without children, being part of a couple and having children is associated with higher participation of men, but lower participation of women. Similarly, more children are associated with lower participation of women, but higher participation of men, consistent with the historical allocation of work across genders within a household. Interestingly, the presence of other employed adults in the household is associated with a higher likelihood of being active, likely pointing to common local labor market effects. These findings should, however, be treated as associations rather than causal effects as labor supply decisions and family composition are likely jointly decided. ${ }^{29}$

Finally, in line with the country-level results, the micro analysis points to significant negative effects of exposure to routine tasks on the probability of being part of the labor force. Working/having worked in an occupation that is more vulnerable to routinization is associated with lower odds of participation. This effect is especially pronounced for workers of ages over 55 . The effects are both statistically and economically significant: a unit change in routinization scores roughly corresponds to the difference in the routinization score of technicians and the routinization score of managers. Whereas about 87 percent of prime-age male managers are active, about 84 percent of prime-age male technicians are in the labor force - the difference in their routinization scores alone can explain about one third of this 3 percentage-point difference in participation rates. ${ }^{30}$

Can policies help those vulnerable to losing their jobs to technology remain active in the labor market? To answer this question, we examine whether various country-level labor market poli-

\footnotetext{
${ }^{27}$ See CEA (2016), Eberstadt (2016), Krause and Sawhill (2017), and Abraham and Kearney (2018) for a review of the literature. Krueger (2017) discusses the poor health status of men not in the labor force, and the rising use of pain medication. Case and Deaton (2017) document an increase in mortality rates due to addiction, depression, and suicide ("deaths of despair") among white, prime-age adults, and hypothesize this may be rooted in the steady deterioration of their job opportunities. Holzer et al. (2005), Pager et al. (2009), and Schmitt and Warner (2010) provide evidence of the drastic increase in incarceration rates, and ex-prisoner population in the United States, who face significant barriers to employment. Aguiar et al. (2017) argue that the decline in labor supply of young men could be linked to improvements in video gaming and other recreational computer activities. It should be noted, however, that the extent and direction of causality of these hypotheses is difficult to establish empirically. Abraham and Kearney (2018) provide a rough quantification of the role of various factors in employment rate trends in the United States since 1999 based on existing studies.

${ }^{28}$ Evidence from sub-national data presented in Koczan and Hilgenstock (2018a), and Koczan and Hilgenstock (2018b) also suggests that the adverse effects of technological progress on participation may have been significantly more pronounced and longer-lasting in the United States than in Europe.

${ }^{29}$ While baseline specifications do not control for household income due to data limitations and endogeneity concerns, we test the robustness of the results to the inclusion of the predicted income decile.

${ }^{30}$ While the baseline specification relies on a cross-country panel, country-by-country estimates confirm these findings: the effects of vulnerability to routinization are significant and negative in most countries.
} 
Table 2: Determinants of Being in the Labor Force

\begin{tabular}{|c|c|c|c|}
\hline & $\begin{array}{c}\text { Men, } \\
\text { ages } 25-54 \\
(1)\end{array}$ & $\begin{array}{c}\text { Women, } \\
\text { ages } 25-54 \\
(2)\end{array}$ & $\begin{array}{c}\text { All, } \\
\text { ages } 55+ \\
(3)\end{array}$ \\
\hline Age & $\begin{array}{c}1.158^{* * *} \\
(0.011)\end{array}$ & $\begin{array}{c}1.320^{* * *} \\
(0.014)\end{array}$ & $\begin{array}{c}1.396^{* * *} \\
(0.113)\end{array}$ \\
\hline Age Squared & $\begin{array}{c}0.998^{* * *} \\
(0.000)\end{array}$ & $\begin{array}{c}0.997^{* * * *} \\
(0.000)\end{array}$ & $\begin{array}{c}0.998^{* * *} \\
(0.000)\end{array}$ \\
\hline Male & & & $\begin{array}{c}1.196^{* * *} \\
(0.031)\end{array}$ \\
\hline Upper Secondary Education & $\begin{array}{c}1.719^{* * * *} \\
(0.032)\end{array}$ & $\begin{array}{c}1.709^{* * *} \\
(0.033)\end{array}$ & $\begin{array}{c}1.209^{* * *} \\
(0.036)\end{array}$ \\
\hline Tertiary Education & $\begin{array}{c}2.759^{* * * *} \\
(0.082)\end{array}$ & $\begin{array}{c}2.961^{* * * *} \\
(0.077)\end{array}$ & $\begin{array}{c}1.594^{* * *} \\
(0.059)\end{array}$ \\
\hline Born in Country & $\begin{array}{c}1.489^{* * *} \\
(0.035)\end{array}$ & $\begin{array}{c}1.333^{* * *} \\
(0.024)\end{array}$ & $\begin{array}{c}1.091^{* *} \\
(0.046)\end{array}$ \\
\hline Urban & $\begin{array}{c}1.008 \\
(0.019)\end{array}$ & $\begin{array}{l}1.024^{*} \\
(0.013)\end{array}$ & $\begin{array}{c}1.019 \\
(0.027)\end{array}$ \\
\hline Number of Children in Household & $\begin{array}{c}1.049^{* * *} \\
(0.009)\end{array}$ & $\begin{array}{c}0.816^{* * *} \\
(0.006)\end{array}$ & $\begin{array}{l}0.960^{*} \\
(0.020)\end{array}$ \\
\hline One Adult with Children & $\begin{array}{c}1.042 \\
(0.059)\end{array}$ & $\begin{array}{c}0.846^{* * *} \\
(0.026)\end{array}$ & $\begin{array}{c}1.785^{* * *} \\
(0.394)\end{array}$ \\
\hline Couple without Children & $\begin{array}{c}1.356^{* * * *} \\
(0.035)\end{array}$ & $\begin{array}{c}0.906^{* * *} \\
(0.034)\end{array}$ & $\begin{array}{c}0.842^{* * *} \\
(0.025)\end{array}$ \\
\hline Couple with Children & $\begin{array}{c}1.726^{* * *} \\
(0.052)\end{array}$ & $\begin{array}{c}0.757^{* * *} * \\
(0.028)\end{array}$ & $\begin{array}{c}1.446^{* * *} \\
(0.128)\end{array}$ \\
\hline Other Household Structure & $\begin{array}{c}0.937^{* *} \\
(0.027)\end{array}$ & $\begin{array}{c}0.868^{* * * *} \\
(0.030)\end{array}$ & $\begin{array}{c}0.812^{* * *} \\
(0.038)\end{array}$ \\
\hline Other Employed Adult(s) in Household & $\begin{array}{c}1.497^{* * *} \\
(0.035)\end{array}$ & $\begin{array}{c}1.152^{* * *} \\
(0.038)\end{array}$ & $\begin{array}{c}1.703^{* * *} \\
(0.091)\end{array}$ \\
\hline RTI Score of Occupation & $\begin{array}{c}0.825^{* * *} \\
(0.010)\end{array}$ & $\begin{array}{c}0.900^{* * *} \\
(0.010)\end{array}$ & $\begin{array}{c}0.716^{* * *} \\
(0.013)\end{array}$ \\
\hline Lagged Output Gap & $\begin{array}{c}1.037^{* * *} * \\
(0.006)\end{array}$ & $\begin{array}{c}1.023^{* * *} \\
(0.004)\end{array}$ & $\begin{array}{c}1.031^{* * *} \\
(0.007)\end{array}$ \\
\hline Number of Observations & 491,820 & 474,240 & 86,441 \\
\hline \multicolumn{4}{|c|}{$\begin{array}{l}\text { Source: Authors' calculations. } \\
\text { Notes: Logit regressions are based on a random sample of } 10,000 \text { respondents per } \\
\text { country per year from } 19 \text { countries. The table reports exponentiated coefficients. All } \\
\text { specifications include country, region, and year fixed effects. The base category for } \\
\text { education is "up to lower secondary education", for family composition the base cat- } \\
\text { egory is "one adult without children". Standard errors clustered at the country-year } \\
\text { level. ***, **, and * indicate statistical significance at } 1,5 \text {, and } 10 \text { percent, respec- } \\
\text { tively. }\end{array}$} \\
\hline
\end{tabular}

cies, such as spending on active labor market programs or employment protection, can offset some of the negative effect of routinizability on participation. We augment the logit model described above with an interaction between the routinization score and the relevant policy measure. Table 3 reports the effect of a unit change in the routinization score, estimated at the 25 th and 75 th percentiles of the distribution of policies (in other words, in countries with relatively low versus relatively high spending on active labor market programs, and the like).

Policies can offset at least some of the negative association between routinization and participation. In particular, higher spending on active labor market programs seems to attenuate the link between participation and routinizability of occupation. The negative association between routinizability and participation is about one-third as large in countries at the 75 th percentile of active labor market spending as in countries at the 25th percentile. Disaggregated data on different active labor market programs suggest that the finding is driven by spending on training, which mitigates some of the negative effect for prime-age women. ${ }^{31}$

\footnotetext{
${ }^{31}$ It should, however, be added that active labor market programs can be expensive, their success hinges cru-
} 
While policies appear to help somewhat in offsetting the effects of routinization for prime-age workers, the negative effects of routinizability are larger for older workers, and policies also provide less of an offset.

Table 3: Effects of Policies on the Relationship between Participation and Routinization

\begin{tabular}{|c|c|c|c|c|c|}
\hline & & \multicolumn{2}{|c|}{ Men, ages $25-54$} & \multicolumn{2}{|c|}{ Women, ages $25-54$} \\
\hline & & $\delta y / \delta x$ & $\begin{array}{c}\text { Std. } \\
\text { error }\end{array}$ & $\delta y / \delta x$ & $\begin{array}{c}\text { Std. } \\
\text { error }\end{array}$ \\
\hline \multirow[t]{2}{*}{ ALMP spending*+ } & 25 th & -0.022 & 0.002 & -0.015 & 0.002 \\
\hline & 75 th & -0.011 & 0.001 & -0.008 & 0.001 \\
\hline \multirow[t]{2}{*}{ ALMP spending on training +} & 25 th & -0.012 & 0.003 & -0.014 & 0.004 \\
\hline & 75 th & -0.016 & 0.002 & -0.008 & 0.003 \\
\hline \multirow[t]{2}{*}{ Education spending +} & 25 th & -0.016 & 0.001 & -0.017 & 0.002 \\
\hline & 75th & -0.018 & 0.001 & -0.010 & 0.002 \\
\hline \multirow[t]{2}{*}{ Product market deregulation*+ } & 25 th & -0.019 & 0.002 & -0.011 & 0.003 \\
\hline & 75 th & -0.012 & 0.002 & -0.014 & 0.003 \\
\hline \multirow[t]{2}{*}{ Wage-setting coordination* } & 25 th & -0.021 & 0.001 & -0.015 & 0.002 \\
\hline & 75 th & -0.013 & 0.001 & -0.010 & 0.002 \\
\hline \multirow{2}{*}{ Employment protection* +} & 25 th & -0.019 & 0.001 & -0.013 & 0.002 \\
\hline & 75 th & -0.013 & 0.001 & -0.009 & 0.002 \\
\hline \multirow{2}{*}{ Location* +} & Rural & -0.019 & 0.001 & -0.017 & 0.002 \\
\hline & Urban & -0.016 & 0.001 & -0.012 & 0.001 \\
\hline
\end{tabular}

Source: Authors' calculations.

Notes: Logit regressions are based on a random sample of 10,000 respondents a country a year of 19 countries, controlling for individual characteristics, household composition, year-, country- and region-fixed effects as well as the output gap, trade openness, and the service to industry employment ratio. Standard errors clustered at the country-year level. ${ }^{*}(+)$ denotes effects are significantly different from each other at the 10 percent level for men (women).

\subsection{Robustness}

In Tables 4 to 8 , we report numerous robustness checks for the cross-country panel regressions. Specifically, Table 4 contains the estimated coefficients for the regression of the young, Table 5 of the prime-age male workers, Table 6 of the prime-age female workers, Table 7 of older workers, and Table 8 of the aggregate participation rate. Each table shows the results from the baseline specification, and establishes its robustness to alternative measures, specification, error structure, among others.

In general, the results are robust to:

- Applying the logistic transformation: As participation rates are bounded by 0 and 100 by construction, the analysis is repeated using the logistic transformation of the dependent variable in column (2).

- Alternative corrections to standard errors:

- Cross-equation correlation: Correlation across the error terms of the estimations for different worker groups may be present. Estimating a system including one equation for

cially on specific design features, and evidence on their effectiveness more broadly is mixed (see IMF/WB/WTO, 2017 for a recent literature review). Surveying the evidence from North American and European studies, Heckman et al. (1999) conclude that public employment and training programs had at best a modest positive impact on earnings by raising employment probability. Card et al. (2010) find substantial variation in estimated program effectiveness across studies. 
each group in a seemingly unrelated regression (SUR) framework returns similar results in column (3). ${ }^{32}$

- Cross-sectional dependence: Tests by Pesaran and Frees reject the null hypothesis of cross-sectional independence, but the results of the Friedman test suggest that crosssectional dependence is not present. The results, however, are generally robust to alternative corrections of the standard errors. In particular, the conclusions are broadly unchanged when employing the Beck and Katz (1995) estimator in column (4), correcting the standard errors only for heteroskedasticity and autocorrelation in column (5), and adopting the Newey-West correction for the standard errors in column (6).

- Collapsing the dataset to five-year averages: Possible distortions arising from inability to control for cyclical effects are eliminated by estimating the equation on five-year averages. This estimation also rules out the possibility that the results depend on some undetected local unit root. The results are broadly comparable to those of the baseline estimations as presented in column (7).

- Excluding the global financial crisis: The significance and the magnitude of the coefficients is not affected by dropping 2008 and 2009 from the sample, as shown in column (8).

- Including other AEs: Broadening the sample to countries that were classified as advanced in the World Economic Outlook database after 2006 does not generally alter the results, as can be seen in column (9).

- Alternative measures of the output gap: In column (10), the analysis replaces the output gap with the unemployment rate. This specification returns qualitatively comparable results. However, in this case, prime-age men and older workers' participation rates turn out to be sensitive to the cyclical conditions of the economy.

- Sample selection: The analysis rules out the possibility that single countries drive the results by estimating the same specification dropping one country at a time. The estimation results display a remarkable stability of the estimates, as is shown in column (11). This exercise also allays concerns that the findings on the role of certain variables may be an artifact of measurement errors in the series of some countries.

\footnotetext{
${ }^{32}$ In the case of the regression of the aggregate participation rate, the SUR is not estimated.
} 
Figure 7: Average Contributions to Changes in Participation Rates, 1995-2011

(Percentage points)

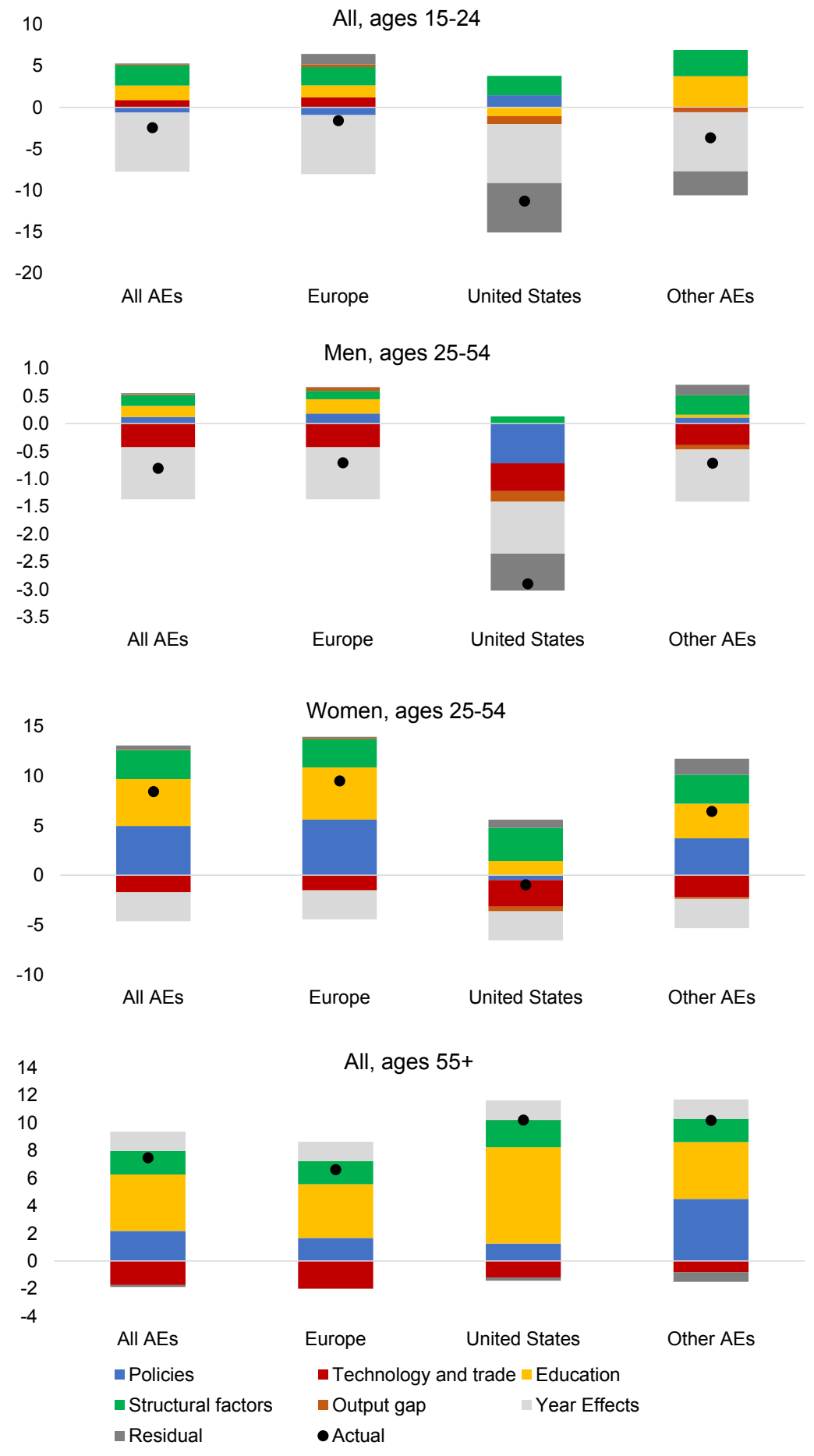

Source: Authors' calculations.

Notes: Other AEs include Australia, Canada, Japan, and New Zealand. 
Table 4: Drivers of Youth (Ages 15-24) Labor Force Participation Rates, Robustness

\begin{tabular}{|c|c|c|c|c|c|c|c|c|c|c|c|}
\hline & Baseline & $\begin{array}{c}\text { Logistic } \\
\text { transfor- } \\
\text { mation }\end{array}$ & SUR & $\begin{array}{l}\text { Beck and } \\
\text { Katz }\end{array}$ & $\begin{array}{l}\text { HAC } \\
\text { standard } \\
\text { errors }\end{array}$ & $\begin{array}{l}\text { Newey- } \\
\text { West } \\
\text { standard } \\
\text { errors }\end{array}$ & $\begin{array}{c}\text { 5-year } \\
\text { averages }\end{array}$ & $\begin{array}{l}\text { Excluding } \\
\text { GFC }\end{array}$ & $\begin{array}{l}\text { Including } \\
\text { all AEs }\end{array}$ & $\begin{array}{c}\text { Replacing } \\
\text { output } \\
\text { gap with } \\
\text { unem- } \\
\text { ployment } \\
\text { rate } \\
(10) \\
\end{array}$ & $\begin{array}{l}\text { Dropping one } \\
\text { country at a } \\
\text { time }\end{array}$ \\
\hline Lag of Output Gap & $\begin{array}{c}0.360^{* * *} \\
(0.112)\end{array}$ & $\begin{array}{c}0.015 * * * \\
(0.005)\end{array}$ & $\begin{array}{c}0.219 * * * \\
(0.073)\end{array}$ & $\begin{array}{c}0.226 * * * \\
(0.063)\end{array}$ & $\begin{array}{c}0.366^{* * * *} \\
(0.080)\end{array}$ & $\begin{array}{c}0.360^{* * * *} \\
(0.103)\end{array}$ & $\begin{array}{l}0.473^{* *} \\
(0.183)\end{array}$ & $\begin{array}{c}0.366 * * * \\
(0.121)\end{array}$ & $\begin{array}{c}0.286^{* * *} \\
(0.100)\end{array}$ & $\begin{array}{c}-0.519 * * * \\
(0.100)\end{array}$ & $\begin{array}{c}0.354 \\
(0.292 ; 0.393)\end{array}$ \\
\hline Routinization*Relative Price of Investment & $\begin{array}{l}0.303 \\
(0.299)\end{array}$ & $\begin{array}{c}0.012 \\
(0.012)\end{array}$ & $\begin{array}{r}0.313 \\
(0.280)\end{array}$ & $\begin{array}{l}-0.143 \\
(0.377)\end{array}$ & $\begin{array}{l}0.303 \\
(0.262)\end{array}$ & $\begin{array}{l}0.303 \\
(0.344)\end{array}$ & $\begin{array}{l}0.358 \\
(0.299)\end{array}$ & $\begin{array}{l}0.358 \\
(0.313)\end{array}$ & $\begin{array}{c}0.295 \\
(0.291)\end{array}$ & $\begin{array}{l}0.404 \\
(0.293)\end{array}$ & $\begin{array}{c}0.297 \\
(0.184 ; 0.489)\end{array}$ \\
\hline Lag of Trade Openness & $\begin{array}{c}0.059^{* * *} \\
(0.022)\end{array}$ & $\begin{array}{c}0.003 * * * \\
(0.001)\end{array}$ & $\begin{array}{c}0.045 * * * \\
(0.016)\end{array}$ & $\begin{array}{l}0.020 \\
(0.019)\end{array}$ & $\begin{array}{c}0.0599^{* * *} \\
(0.018)\end{array}$ & $\begin{array}{c}0.059^{* * * *} \\
(0.019)\end{array}$ & $\begin{array}{l}0.059^{*} \\
(0.026)\end{array}$ & $\begin{array}{l}0.053^{* *} \\
(0.024)\end{array}$ & $\begin{array}{l}0.043^{*} \\
(0.022)\end{array}$ & $\begin{array}{l}0.021 \\
(0.028)\end{array}$ & $\begin{array}{c}0.057 \\
(0.045 ; 0.071)\end{array}$ \\
\hline Relative Service Employment & $\begin{array}{l}-0.002 \\
(0.010)\end{array}$ & $\begin{array}{l}-0.000 \\
(0.000)\end{array}$ & $\begin{array}{c}-0.026^{* * * *} \\
(0.008)\end{array}$ & $\begin{array}{c}-0.020^{* *} \\
(0.009)\end{array}$ & $\begin{array}{l}-0.002 \\
(0.009)\end{array}$ & $\begin{array}{l}-0.002 \\
(0.011)\end{array}$ & $\begin{array}{l}-0.004 \\
(0.012)\end{array}$ & $\begin{array}{l}-0.004 \\
(0.009)\end{array}$ & $\begin{array}{c}0.002 \\
(0.009)\end{array}$ & $\begin{array}{c}0.004 \\
(0.009)\end{array}$ & $\begin{array}{c}-0.001 \\
(-0.01 ; 0.001)\end{array}$ \\
\hline Lag of Urbanization & $\begin{array}{c}0.668^{* * * *} \\
(0.142)\end{array}$ & $\begin{array}{c}0.030^{* * *} \\
(0.006)\end{array}$ & $\begin{array}{l}-0.089 \\
(0.098)\end{array}$ & $\begin{array}{c}0.575^{* * *} \\
(0.135)\end{array}$ & $\begin{array}{c}0.668^{* * * *} \\
(0.085)\end{array}$ & $\begin{array}{c}0.668^{* * *} \\
(0.159)\end{array}$ & $\begin{array}{c}0.560^{* * *} \\
(0.139)\end{array}$ & $\begin{array}{c}0.700^{* * *} \\
(0.170)\end{array}$ & $\begin{array}{c}0.685^{* * *} \\
(0.139)\end{array}$ & $\begin{array}{c}0.715^{* * *} \\
(0.175)\end{array}$ & $\begin{array}{c}0.669 \\
(0.626 ; 0.702)\end{array}$ \\
\hline Education (\% Secondary) & $\begin{array}{l}-0.050 \\
(0.042)\end{array}$ & $\begin{array}{l}-0.002 \\
(0.002)\end{array}$ & $\begin{array}{c}0.007 \\
(0.022)\end{array}$ & $\begin{array}{l}-0.042 \\
(0.032)\end{array}$ & $\begin{array}{l}-0.050^{*} \\
(0.026)\end{array}$ & $\begin{array}{l}-0.050 \\
(0.036)\end{array}$ & $\begin{array}{l}-0.049 \\
(0.060)\end{array}$ & $\begin{array}{l}-0.062 \\
(0.049)\end{array}$ & $\begin{array}{l}-0.050 \\
(0.042)\end{array}$ & $\begin{array}{l}-0.050 \\
(0.049)\end{array}$ & $\begin{array}{c}-0.049 \\
(-0.076 ;-0.031)\end{array}$ \\
\hline Education (\% Tertiary) & $\begin{array}{c}-0.275^{* * * *} \\
(0.057)\end{array}$ & $\begin{array}{c}-0.012^{* * *} \\
(0.002)\end{array}$ & $\begin{array}{c}-0.105^{* * *} \\
(0.038)\end{array}$ & $\begin{array}{c}-0.227^{* * * *} \\
(0.047)\end{array}$ & $\begin{array}{c}-0.275^{* * *} \\
(0.042)\end{array}$ & $\begin{array}{c}-0.275^{* * * *} \\
(0.054)\end{array}$ & $\begin{array}{l}-0.253^{*} \\
(0.105)\end{array}$ & $\begin{array}{c}-0.290^{* * * *} \\
(0.064)\end{array}$ & $\begin{array}{c}-0.286^{* * * *} \\
(0.048)\end{array}$ & $\begin{array}{c}-0.294^{* * * *} \\
(0.062)\end{array}$ & $\begin{array}{c}-0.273 \\
(-0.303 ;-0.247)\end{array}$ \\
\hline Tax wedge & $\begin{array}{l}-0.103 \\
(0.064)\end{array}$ & $\begin{array}{l}-0.005^{*} \\
(0.003)\end{array}$ & $\begin{array}{l}-0.021 \\
(0.046)\end{array}$ & $\begin{array}{l}-0.029 \\
(0.050)\end{array}$ & $\begin{array}{c}-0.103^{* *} \\
(0.048)\end{array}$ & $\begin{array}{l}-0.103^{*} \\
(0.058)\end{array}$ & $\begin{array}{l}-0.086 \\
(0.060)\end{array}$ & $\begin{array}{l}-0.082 \\
(0.064)\end{array}$ & $\begin{array}{l}-0.094 \\
(0.059)\end{array}$ & $\begin{array}{c}0.057 \\
(0.074)\end{array}$ & $\begin{array}{c}-0.104 \\
(-0.127:-0.058)\end{array}$ \\
\hline Unemployment Replacement Ratio & $\begin{array}{l}-0.002 \\
(0.068)\end{array}$ & $\begin{array}{l}-0.000 \\
(0.003)\end{array}$ & $\begin{array}{c}0.1111^{* * *} \\
(0.035)\end{array}$ & $\begin{array}{l}0.009 \\
(0.044)\end{array}$ & $\begin{array}{l}-0.002 \\
(0.039)\end{array}$ & $\begin{array}{l}-0.002 \\
(0.059)\end{array}$ & $\begin{array}{l}-0.001 \\
(0.140)\end{array}$ & $\begin{array}{c}0.016 \\
(0.070)\end{array}$ & $\begin{array}{l}-0.009 \\
(0.065)\end{array}$ & $\begin{array}{c}0.007 \\
(0.066)\end{array}$ & $\begin{array}{c}0.003 \\
(-0.036 ; 0.034)\end{array}$ \\
\hline Public Spending on ALMP & $\begin{array}{c}0.041^{* * * *} \\
(0.014)\end{array}$ & $\begin{array}{l}0.002^{* *} \\
(0.001)\end{array}$ & $\begin{array}{l}-0.004 \\
(0.013)\end{array}$ & $\begin{array}{c}0.031 \\
(0.023)\end{array}$ & $\begin{array}{c}0.041^{* * * *} \\
(0.014)\end{array}$ & $\begin{array}{l}0.041^{* *} \\
(0.019)\end{array}$ & $\begin{array}{c}0.023 \\
(0.033)\end{array}$ & $\begin{array}{c}0.048^{* * *} \\
(0.014)\end{array}$ & $\begin{array}{c}0.045^{* * *} \\
(0.014)\end{array}$ & $\begin{array}{l}0.030^{*} \\
(0.017)\end{array}$ & $\begin{array}{c}0.041 \\
(0.036 ; 0.048)\end{array}$ \\
\hline Restrictiveness of Migrant Integration Policies & $\begin{array}{c}0.491^{* * *} \\
(0.098)\end{array}$ & $\begin{array}{c}0.021 * * * \\
(0.004)\end{array}$ & $\begin{array}{c}0.422^{* * * *} \\
(0.079)\end{array}$ & $\begin{array}{l}0.277^{* *} \\
(0.108)\end{array}$ & $\begin{array}{c}0.491 * * * \\
(0.090)\end{array}$ & $\begin{array}{c}0.491^{* * * *} \\
(0.146)\end{array}$ & $\begin{array}{c}0.522^{* * * *} \\
(0.091)\end{array}$ & $\begin{array}{c}0.492^{* * * *} \\
(0.109)\end{array}$ & $\begin{array}{c}0.464 * * * \\
(0.094)\end{array}$ & $\begin{array}{c}0.421^{* * *} \\
(0.114)\end{array}$ & $\begin{array}{c}0.487 \\
(0.414 ; 0.539)\end{array}$ \\
\hline Union Density & $\begin{array}{l}-0.009 \\
(0.068)\end{array}$ & $\begin{array}{l}-0.000 \\
(0.003)\end{array}$ & $\begin{array}{l}-0.065 \\
(0.046)\end{array}$ & $\begin{array}{c}-0.116^{* *} \\
(0.057)\end{array}$ & $\begin{array}{l}-0.009 \\
(0.046)\end{array}$ & $\begin{array}{l}-0.009 \\
(0.066)\end{array}$ & $\begin{array}{l}-0.021 \\
(0.091)\end{array}$ & $\begin{array}{l}-0.020 \\
(0.069)\end{array}$ & $\begin{array}{l}-0.001 \\
(0.061)\end{array}$ & $\begin{array}{c}0.011 \\
(0.065)\end{array}$ & $\begin{array}{c}-0.01 \\
(-0.026 ; 0.016)\end{array}$ \\
\hline Coordination of Wage-setting & $\begin{array}{c}1.104^{* * *} \\
(0.245)\end{array}$ & $\begin{array}{c}0.045^{* * *} \\
(0.010)\end{array}$ & $\begin{array}{c}0.942^{* * *} \\
(0.241)\end{array}$ & $\begin{array}{l}0.081 \\
(0.180)\end{array}$ & $\begin{array}{c}1.104^{* * *} \\
(0.251)\end{array}$ & $\begin{array}{c}1.104^{* * * *} \\
(0.329)\end{array}$ & $\begin{array}{c}1.848 * * * \\
(0.451)\end{array}$ & $\begin{array}{c}1.117 * * * \\
(0.252)\end{array}$ & $\begin{array}{c}1.088^{* * *} \\
(0.233)\end{array}$ & $\begin{array}{l}0.694^{* *} \\
(0.284)\end{array}$ & $\begin{array}{c}1.105 \\
(0.852 ; 1.255)\end{array}$ \\
\hline & 57 & 57 & 48 & 57 & 57 & 57 & 13 & $52:$ & 59 & 52 & \\
\hline & 0515 & 0.521 & 23 & 0922 & 0.515 & 0.515 & 0.573 & 052 & 0 & 0.540 & \\
\hline$R$-squared & 0.515 & 0.521 & & 0.922 & 0.515 & 0.515 & 0.573 & 0.529 & 0.517 & 0.540 & \\
\hline
\end{tabular}

Source: Authors' calculations,

Notes: All specifications include country and year fixed effects. Column (1) reports the baseline estimation results; column (2) reports the results after applying the logistic transformation to the dependent variable; column (3) reports the estimates from a seemingly unrelated regressions (SUR) estimation of a 4-equation system (one for each group); column (4) shows the results using the

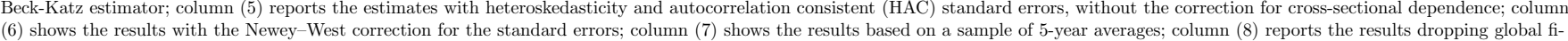
nancial crisis (GFC) years 2008 and 2009 from the sample; column (9) reports the coefficients when the sample includes countries that became AEs after 1980; column (10) shows the results when the lag of the time from the sanle. Dis and $*$ indicate statistical significance at 1,5 , and 10 percent, respectively. 
Table 5: Drivers of Prime-age Men (Ages 25-54) Labor Force Participation Rates, Robustness

\begin{tabular}{|c|c|c|c|c|c|c|c|c|c|c|c|}
\hline & Baseline & $\begin{array}{c}\text { Logistic } \\
\text { transfor- } \\
\text { mation }\end{array}$ & SUR & $\begin{array}{l}\text { Beck and } \\
\text { Katz }\end{array}$ & $\begin{array}{l}\text { HAC } \\
\text { standard } \\
\text { errors }\end{array}$ & $\begin{array}{l}\text { Newey- } \\
\text { West } \\
\text { standard } \\
\text { errors }\end{array}$ & $\begin{array}{c}5 \text {-year } \\
\text { averages }\end{array}$ & $\begin{array}{l}\text { Excluding } \\
\text { GFC }\end{array}$ & $\begin{array}{l}\text { Including } \\
\text { all AEs }\end{array}$ & $\begin{array}{c}\text { Replacing } \\
\text { output } \\
\text { gap with } \\
\text { unem- } \\
\text { ployment } \\
\text { rate } \\
(10) \\
\end{array}$ & $\begin{array}{l}\text { Dropping one } \\
\text { country at a } \\
\text { time }\end{array}$ \\
\hline Lag of Output Gap & $\begin{array}{c}0.072^{* * *} * \\
(0.020)\end{array}$ & $\begin{array}{c}0.012^{* * *} \\
(0.003)\end{array}$ & $\begin{array}{c}0.058^{* * *} \\
(0.017)\end{array}$ & $\begin{array}{c}0.020 \\
(0.016)\end{array}$ & $\begin{array}{c}0.072^{* * *} * \\
(0.018)\end{array}$ & $\begin{array}{c}0.072 * * * \\
(0.022)\end{array}$ & $\begin{array}{c}0.117^{* *} \\
(0.037)\end{array}$ & $\begin{array}{c}0.070^{* * *} \\
(0.022)\end{array}$ & $\begin{array}{c}0.062^{* * *} \\
(0.019)\end{array}$ & $\begin{array}{l}-0.002 \\
(0.029)\end{array}$ & $\begin{array}{c}0.07 \\
(0.06 ; 0.081)\end{array}$ \\
\hline Routinization*Relative Price of Investment & $\begin{array}{c}0.302 * * * \\
(0.048)\end{array}$ & $\begin{array}{c}0.070^{* * *} \\
(0.011)\end{array}$ & $\begin{array}{c}0.204^{* * *} \\
(0.067)\end{array}$ & $\begin{array}{c}0.2177^{* * *} \\
(0.057)\end{array}$ & $\begin{array}{c}0.3022^{* * *} \\
(0.057)\end{array}$ & $\begin{array}{c}0.3022 * * * \\
(0.074)\end{array}$ & $\begin{array}{c}0.266^{* * * *} \\
(0.072)\end{array}$ & $\begin{array}{c}0.303^{* * *} \\
(0.048)\end{array}$ & $\begin{array}{c}0.284^{* * * *} \\
(0.037)\end{array}$ & $\begin{array}{c}0.315^{* * *} \\
(0.049)\end{array}$ & $\begin{array}{c}0.302 \\
(0.285 ; 0.33)\end{array}$ \\
\hline Lag of Trade Openness & $\begin{array}{l}-0.005 \\
(0.005)\end{array}$ & $\begin{array}{l}-0.001 \\
(0.001)\end{array}$ & $\begin{array}{c}-0.012^{* * *} \\
(0.004)\end{array}$ & $\begin{array}{c}-0.015^{* * *} \\
(0.005)\end{array}$ & $\begin{array}{l}-0.005 \\
(0.004)\end{array}$ & $\begin{array}{l}-0.005 \\
(0.005)\end{array}$ & $\begin{array}{l}-0.003 \\
(0.009)\end{array}$ & $\begin{array}{l}-0.007 \\
(0.006)\end{array}$ & $\begin{array}{l}-0.005 \\
(0.004)\end{array}$ & $\begin{array}{l}-0.010 \\
(0.006)\end{array}$ & $\begin{array}{c}-0.005 \\
(-0.006 ;-0.003)\end{array}$ \\
\hline Relative Service Employment & $\begin{array}{l}-0.002 \\
(0.002)\end{array}$ & $\begin{array}{l}-0.000 \\
(0.000)\end{array}$ & $\begin{array}{l}-0.000 \\
(0.002)\end{array}$ & $\begin{array}{l}-0.000 \\
(0.002)\end{array}$ & $\begin{array}{l}-0.002 \\
(0.002)\end{array}$ & $\begin{array}{l}-0.002 \\
(0.002)\end{array}$ & $\begin{array}{c}0.001 \\
(0.002)\end{array}$ & $\begin{array}{l}-0.002 \\
(0.002)\end{array}$ & $\begin{array}{l}-0.003 \\
(0.002)\end{array}$ & $\begin{array}{l}-0.002 \\
(0.002)\end{array}$ & $\begin{array}{c}-0.002 \\
(-0.003 ;-0.001)\end{array}$ \\
\hline Lag of Urbanization & $\begin{array}{c}0.101^{* * * *} \\
(0.019)\end{array}$ & $\begin{array}{c}0.015^{* * *} \\
(0.004)\end{array}$ & $\begin{array}{c}0.006 \\
(0.023)\end{array}$ & $\begin{array}{c}0.105^{* * *} \\
(0.027)\end{array}$ & $\begin{array}{c}0.101^{* * * *} \\
(0.019)\end{array}$ & $\begin{array}{c}0.101^{* * *} \\
(0.020)\end{array}$ & $\begin{array}{c}0.072^{* *} \\
(0.023)\end{array}$ & $\begin{array}{c}0.105^{* * *} \\
(0.023)\end{array}$ & $\begin{array}{c}0.104^{* * *} \\
(0.020)\end{array}$ & $\begin{array}{c}0.110^{* * * *} \\
(0.026)\end{array}$ & $\begin{array}{c}0.101 \\
(0.091 ; 0.114)\end{array}$ \\
\hline Education (\% Secondary) & $\begin{array}{c}0.019 * * * \\
(0.007)\end{array}$ & $\begin{array}{l}0.003^{* *} \\
(0.001)\end{array}$ & $\begin{array}{c}0.037 * * * \\
(0.008)\end{array}$ & $\begin{array}{c}0.022 * * * \\
(0.009)\end{array}$ & $\begin{array}{l}0.019^{* *} \\
(0.008)\end{array}$ & $\begin{array}{l}0.019^{* *} \\
(0.009)\end{array}$ & $\begin{array}{l}0.015^{* *} \\
(0.005)\end{array}$ & $\begin{array}{c}0.022^{* * *} \\
(0.007)\end{array}$ & $\begin{array}{l}0.018^{* *} \\
(0.007)\end{array}$ & $\begin{array}{c}0.023^{* * *} \\
(0.008)\end{array}$ & $\begin{array}{c}0.019 \\
(0.016 ; 0.026)\end{array}$ \\
\hline Education (\% Tertiary) & $\begin{array}{c}0.019 \\
(0.015)\end{array}$ & $\begin{array}{c}0.001 \\
(0.002)\end{array}$ & $\begin{array}{l}0.023^{* *} \\
(0.010)\end{array}$ & $\begin{array}{l}0.030^{*} \\
(0.016)\end{array}$ & $\begin{array}{l}0.019^{*} \\
(0.010)\end{array}$ & $\begin{array}{c}0.019 \\
(0.012)\end{array}$ & $\begin{array}{l}0.017 \\
(0.019)\end{array}$ & $\begin{array}{l}0.027 \\
(0.019)\end{array}$ & $\begin{array}{c}0.018 \\
(0.014)\end{array}$ & $\begin{array}{l}0.029 \\
(0.018)\end{array}$ & $\begin{array}{c}0.018 \\
(0.012 ; 0.027)\end{array}$ \\
\hline Tax wedge & $\begin{array}{l}-0.002 \\
(0.015)\end{array}$ & $\begin{array}{l}-0.003 \\
(0.002)\end{array}$ & $\begin{array}{l}-0.009 \\
(0.010)\end{array}$ & $\begin{array}{c}0.005 \\
(0.011)\end{array}$ & $\begin{array}{l}-0.002 \\
(0.010)\end{array}$ & $\begin{array}{l}-0.002 \\
(0.010)\end{array}$ & $\begin{array}{l}-0.002 \\
(0.027)\end{array}$ & $\begin{array}{l}-0.001 \\
(0.016)\end{array}$ & $\begin{array}{c}0.004 \\
(0.014)\end{array}$ & $\begin{array}{l}0.002 \\
(0.017)\end{array}$ & $\begin{array}{c}-0.002 \\
(-0.007 ; 0.001)\end{array}$ \\
\hline Unemployment Replacement Ratio & $\begin{array}{c}-0.041^{* * * *} \\
(0.007)\end{array}$ & $\begin{array}{c}-0.007^{* * * *} \\
(0.001)\end{array}$ & $\begin{array}{c}-0.037^{* * * *} \\
(0.008)\end{array}$ & $\begin{array}{c}-0.024^{* *} \\
(0.010)\end{array}$ & $\begin{array}{c}-0.041^{* * * *} \\
(0.008)\end{array}$ & $\begin{array}{c}-0.041^{* * *} \\
(0.011)\end{array}$ & $\begin{array}{c}-0.031^{* * * *} \\
(0.008)\end{array}$ & $\begin{array}{c}-0.041^{* * * *} \\
(0.008)\end{array}$ & $\begin{array}{c}-0.039^{* * *} \\
(0.008)\end{array}$ & $\begin{array}{c}-0.044^{* * *} \\
(0.008)\end{array}$ & $\begin{array}{c}-0.04 \\
(-0.045 ;-0.034)\end{array}$ \\
\hline Public Spending on ALMP & $\begin{array}{c}0.005 \\
(0.005)\end{array}$ & $\begin{array}{c}0.001 \\
(0.001)\end{array}$ & $\begin{array}{l}-0.000 \\
(0.003)\end{array}$ & $\begin{array}{c}0.005 \\
(0.005)\end{array}$ & $\begin{array}{l}0.005 \\
(0.003)\end{array}$ & $\begin{array}{l}0.005 \\
(0.005)\end{array}$ & $\begin{array}{l}0.005 \\
(0.009)\end{array}$ & $\begin{array}{c}0.007 \\
(0.005)\end{array}$ & $\begin{array}{l}0.006 \\
(0.005)\end{array}$ & $\begin{array}{l}0.010^{*} \\
(0.005)\end{array}$ & $\begin{array}{c}0.005 \\
(0.004 ; 0.006)\end{array}$ \\
\hline Restrictiveness of Migrant Integration Policies & $\begin{array}{c}-0.047^{* *} \\
(0.020)\end{array}$ & $\begin{array}{c}-0.007^{* *} \\
(0.003)\end{array}$ & $\begin{array}{c}-0.052^{* * *} \\
(0.019)\end{array}$ & $\begin{array}{l}-0.019 \\
(0.024)\end{array}$ & $\begin{array}{c}-0.047^{* *} \\
(0.020)\end{array}$ & $\begin{array}{c}-0.047^{* *} \\
(0.023)\end{array}$ & $\begin{array}{c}-0.092^{* *} \\
(0.025)\end{array}$ & $\begin{array}{c}-0.053^{* *} \\
(0.020)\end{array}$ & $\begin{array}{c}-0.048^{* *} \\
(0.021)\end{array}$ & $\begin{array}{c}-0.056^{* *} \\
(0.022)\end{array}$ & $\begin{array}{c}-0.046 \\
(-0.062 ;-0.034)\end{array}$ \\
\hline Union Density & $\begin{array}{l}-0.001 \\
(0.011)\end{array}$ & $\begin{array}{c}0.002 \\
(0.002)\end{array}$ & $\begin{array}{l}-0.016 \\
(0.011)\end{array}$ & $\begin{array}{c}-0.023^{*} \\
(0.012)\end{array}$ & $\begin{array}{c}-0.001 \\
(0.010)\end{array}$ & $\begin{array}{l}-0.001 \\
(0.013)\end{array}$ & $\begin{array}{l}-0.011 \\
(0.019)\end{array}$ & $\begin{array}{l}0.000 \\
(0.011)\end{array}$ & $\begin{array}{l}-0.004 \\
(0.011)\end{array}$ & $\begin{array}{l}-0.000 \\
(0.013)\end{array}$ & $\begin{array}{c}-0.001 \\
(-0.01: 0.007)\end{array}$ \\
\hline Coordination of Wage-setting & $\begin{array}{l}0.131^{* *} \\
(0.063)\end{array}$ & $\begin{array}{l}0.018^{*} \\
(0.010)\end{array}$ & $\begin{array}{c}0.074 \\
(0.057)\end{array}$ & $\begin{array}{l}0.073^{*} \\
(0.040)\end{array}$ & $\begin{array}{l}0.131^{* *} \\
(0.055)\end{array}$ & $\begin{array}{l}0.131^{*} \\
(0.069)\end{array}$ & $\begin{array}{l}0.302^{* *} \\
(0.090)\end{array}$ & $\begin{array}{l}0.134^{*} \\
(0.068)\end{array}$ & $\begin{array}{l}0.139^{* *} \\
(0.062)\end{array}$ & $\begin{array}{c}0.131 \\
(0.080)\end{array}$ & $\begin{array}{c}0.131 \\
(0.117 ; 0.15)\end{array}$ \\
\hline $\mathrm{Ob}$ & 5 & 5 & 48 & 57 & 571 & 57 & 13 & 525 & 593 & 525 & \\
\hline & 23 & 23 & 23 & 23 & 23 & 20 & 23 & 23 & 20 & 23 & \\
\hline$R$-squared & 0.606 & 0.622 & & 0.997 & 0.606 & 0.606 & 0.695 & 0.622 & 0.600 & 0.611 & \\
\hline
\end{tabular}

Notes: All specifications include country and year fixed effects. Column (1) reports the baseline estimation results; column (2) reports the results after applying the logistic transformation to the dependent variable; column (3) reports the estimates from a seemingly unrelated regressions (SUR) estimation of a 4-equation system (one for each group); column (4) shows the results using column (6) shows the results with the Newey-West correction for the standard errors; column (7) shows the results based on a sample of 5-year averages; column (8) reports the results dropping global financial crisis (GFC) years 2008 and 2009 from the sample; column (9) reports the coefficients when the sample includes countries that became AEs after 1980; column (10) shows the results when the lag of the output gap is replaced with the lag of the unemployment rate; and column (11) reports the median coefficient from a distribution of estimates obtained by dropping one (3): HAC standard errors assuming a panel-dependent correlation structure are reported in column (4). Column (11) reports the 10th and 90th percentile of the estimated coefficients in parentheses. ***, **, and * indicate statistical significance at 1,5 , and 10 percent, respectively. 
Table 6: Drivers of Prime-age Women (Ages 25-54) Labor Force Participation Rates, Robustness

\begin{tabular}{|c|c|c|c|c|c|c|c|c|c|c|c|}
\hline & Baseline & $\begin{array}{c}\text { Logistic } \\
\text { transfor- } \\
\text { mation }\end{array}$ & SUR & $\begin{array}{l}\text { Beck and } \\
\text { Katz }\end{array}$ & $\begin{array}{l}\text { HAC } \\
\text { standard } \\
\text { errors }\end{array}$ & $\begin{array}{l}\text { Newey- } \\
\text { West } \\
\text { standard } \\
\text { errors }\end{array}$ & $\begin{array}{c}5 \text {-year } \\
\text { averages }\end{array}$ & $\begin{array}{l}\text { Excluding } \\
\text { GFC }\end{array}$ & $\begin{array}{l}\text { Including } \\
\text { all AEs }\end{array}$ & $\begin{array}{c}\text { Replacing } \\
\text { output } \\
\text { gap with } \\
\text { unem- } \\
\text { ployment } \\
\text { rate } \\
(10) \\
\end{array}$ & $\begin{array}{l}\text { Dropping one } \\
\text { country at a } \\
\text { time }\end{array}$ \\
\hline Lag of Output Gap & $\begin{array}{l}0.170^{*} \\
(0.092)\end{array}$ & $\begin{array}{l}0.008^{*} \\
(0.004)\end{array}$ & $\begin{array}{c}0.180 * * * \\
(0.052)\end{array}$ & $\begin{array}{l}0.114^{* *} \\
(0.050)\end{array}$ & $\begin{array}{c}0.170 * * * \\
(0.056)\end{array}$ & $\begin{array}{l}0.170^{*} \\
(0.095)\end{array}$ & $\begin{array}{c}0.114 \\
(0.223)\end{array}$ & $\begin{array}{l}0.201^{*} \\
(0.098)\end{array}$ & $\begin{array}{c}0.119 \\
(0.072)\end{array}$ & $\begin{array}{c}-0.407 * * \\
(0.151)\end{array}$ & $\begin{array}{c}0.167 \\
(0.139: 0.188)\end{array}$ \\
\hline Routinization*Relative Price of Investment & $\begin{array}{c}1.793 * * * \\
(0.206)\end{array}$ & $\begin{array}{c}0.072 * * * \\
(0.008)\end{array}$ & $\begin{array}{c}1.866 * * * * \\
(0.206)\end{array}$ & $\begin{array}{c}1.245 * * * \\
(0.192)\end{array}$ & $\begin{array}{c}1.793 * * * \\
(0.222)\end{array}$ & $\begin{array}{c}1.793^{* * * *} \\
(0.326)\end{array}$ & $\begin{array}{c}1.565 * * * \\
(0.229)\end{array}$ & $\begin{array}{c}1.722^{* * * *} \\
(0.204)\end{array}$ & $\begin{array}{c}1.578 * * * \\
(0.205)\end{array}$ & $\begin{array}{c}1.692 * * * \\
(0.237)\end{array}$ & $\begin{array}{c}1.781 \\
(1.672: 1.914)\end{array}$ \\
\hline Lag of Trade Openness & $\begin{array}{l}0.010 \\
(0.014)\end{array}$ & $\begin{array}{c}0.000 \\
(0.001)\end{array}$ & $\begin{array}{c}0.016 \\
(0.012)\end{array}$ & $\begin{array}{l}0.009 \\
(0.013)\end{array}$ & $\begin{array}{c}0.010 \\
(0.013)\end{array}$ & $\begin{array}{c}0.010 \\
(0.016)\end{array}$ & $\begin{array}{c}0.013 \\
(0.022)\end{array}$ & $\begin{array}{l}0.022 \\
(0.020)\end{array}$ & $\begin{array}{l}-0.003 \\
(0.011)\end{array}$ & $\begin{array}{c}0.014 \\
(0.018)\end{array}$ & $\begin{array}{c}0.009 \\
(0.002: 0.02)\end{array}$ \\
\hline Relative Service Employment & $\begin{array}{c}0.015^{* * *} \\
(0.005)\end{array}$ & $\begin{array}{l}0.000^{*} \\
(0.000)\end{array}$ & $\begin{array}{c}0.015 * * * \\
(0.005)\end{array}$ & $\begin{array}{l}0.010^{*} \\
(0.006)\end{array}$ & $\begin{array}{l}0.015^{* *} \\
(0.006)\end{array}$ & $\begin{array}{l}0.015^{* *} \\
(0.007)\end{array}$ & $\begin{array}{l}0.017^{* *} \\
(0.006)\end{array}$ & $\begin{array}{c}0.016^{* * * *} \\
(0.005)\end{array}$ & $\begin{array}{c}0.020^{* * * *} \\
(0.005)\end{array}$ & $\begin{array}{c}0.016^{* * *} \\
(0.005)\end{array}$ & $\begin{array}{c}0.015 \\
(0.01 ; 0.019)\end{array}$ \\
\hline Lag of Urbanization & $\begin{array}{c}0.355^{* * *} \\
(0.071)\end{array}$ & $\begin{array}{c}0.021 * * * \\
(0.004)\end{array}$ & $\begin{array}{c}0.373 * * * \\
(0.068)\end{array}$ & $\begin{array}{c}0.313^{* * *} \\
(0.061)\end{array}$ & $\begin{array}{c}0.3555^{* * *} \\
(0.073)\end{array}$ & $\begin{array}{c}0.355 * * * \\
(0.075)\end{array}$ & $\begin{array}{c}0.343^{* * *} \\
(0.048)\end{array}$ & $\begin{array}{c}0.372^{* * * *} \\
(0.079)\end{array}$ & $\begin{array}{c}0.398 * * * \\
(0.078)\end{array}$ & $\begin{array}{c}0.341 * * * \\
(0.077)\end{array}$ & $\begin{array}{c}0.35 \\
(0.299 ; 0.393)\end{array}$ \\
\hline Education (\% Secondary) & $\begin{array}{c}0.2111^{* * *} \\
(0.017)\end{array}$ & $\begin{array}{c}0.010 * * * \\
(0.001)\end{array}$ & $\begin{array}{c}0.203 * * * \\
(0.023)\end{array}$ & $\begin{array}{c}0.247 * * * \\
(0.030)\end{array}$ & $\begin{array}{c}0.211 * * * \\
(0.025)\end{array}$ & $\begin{array}{c}0.211 * * * \\
(0.031)\end{array}$ & $\begin{array}{c}0.187 * * * \\
(0.016)\end{array}$ & $\begin{array}{c}0.215^{* * * *} \\
(0.020)\end{array}$ & $\begin{array}{c}0.195 * * * \\
(0.018)\end{array}$ & $\begin{array}{c}0.222 * * * \\
(0.022)\end{array}$ & $\begin{array}{c}0.209 \\
(0.19 ; 0.236)\end{array}$ \\
\hline Education (\% Tertiary) & $\begin{array}{c}0.332 * * * \\
(0.030)\end{array}$ & $\begin{array}{c}0.016^{* * * *} \\
(0.001)\end{array}$ & $\begin{array}{c}0.268 * * * \\
(0.038)\end{array}$ & $\begin{array}{c}0.360^{* * *} \\
(0.048)\end{array}$ & $\begin{array}{c}0.332 * * * \\
(0.042)\end{array}$ & $\begin{array}{c}0.332^{* * * *} \\
(0.053)\end{array}$ & $\begin{array}{c}0.249^{* * *} \\
(0.049)\end{array}$ & $\begin{array}{c}0.332^{* * * *} \\
(0.035)\end{array}$ & $\begin{array}{c}0.319 * * * \\
(0.031)\end{array}$ & $\begin{array}{c}0.360^{* * *} \\
(0.042)\end{array}$ & $\begin{array}{c}0.333 \\
(0.285 ; 0.374)\end{array}$ \\
\hline Tax wedge & $\begin{array}{c}-0.129^{* * *} \\
(0.029)\end{array}$ & $\begin{array}{l}-0.002 \\
(0.001)\end{array}$ & $\begin{array}{c}-0.134^{* * *} \\
(0.032)\end{array}$ & $\begin{array}{c}-0.095^{* * *} \\
(0.026)\end{array}$ & $\begin{array}{c}-0.129^{* * * *} \\
(0.035)\end{array}$ & $\begin{array}{c}-0.129^{* * *} \\
(0.041)\end{array}$ & $\begin{array}{l}-0.141 \\
(0.071)\end{array}$ & $\begin{array}{c}-0.125^{* * *} \\
(0.028)\end{array}$ & $\begin{array}{c}-0.104^{* * *} \\
(0.029)\end{array}$ & $\begin{array}{c}-0.115^{* * * *} \\
(0.027)\end{array}$ & $\begin{array}{c}-0.13 \\
(-0.158 ;-0.104)\end{array}$ \\
\hline Unemployment Replacement Ratio & $\begin{array}{l}-0.035 \\
(0.033)\end{array}$ & $\begin{array}{l}-0.003 \\
(0.002)\end{array}$ & $\begin{array}{l}-0.036 \\
(0.025)\end{array}$ & $\begin{array}{l}-0.028 \\
(0.021)\end{array}$ & $\begin{array}{l}-0.035 \\
(0.026)\end{array}$ & $\begin{array}{l}-0.035 \\
(0.033)\end{array}$ & $\begin{array}{l}0.044 \\
(0.095)\end{array}$ & $\begin{array}{l}-0.040 \\
(0.035)\end{array}$ & $\begin{array}{l}-0.030 \\
(0.033)\end{array}$ & $\begin{array}{l}-0.048 \\
(0.034)\end{array}$ & $\begin{array}{c}-0.034 \\
(-0.047 ;-0.025)\end{array}$ \\
\hline Public Spending on ALMP & $\begin{array}{c}0.039 * * * \\
(0.006)\end{array}$ & $\begin{array}{c}0.002^{2 * * *} \\
(0.000)\end{array}$ & $\begin{array}{c}0.040^{* * * *} \\
(0.009)\end{array}$ & $\begin{array}{c}0.038^{* * *} \\
(0.008)\end{array}$ & $\begin{array}{c}0.039^{* * *} \\
(0.010)\end{array}$ & $\begin{array}{c}0.039^{* * * *} \\
(0.013)\end{array}$ & $\begin{array}{c}0.022 \\
(0.016)\end{array}$ & $\begin{array}{c}0.038^{* * * *} \\
(0.007)\end{array}$ & $\begin{array}{c}0.046 * * * \\
(0.07)\end{array}$ & $\begin{array}{c}0.042^{* * *} \\
(0.008)\end{array}$ & $\begin{array}{c}0.039 \\
(0.031 ; 0.042)\end{array}$ \\
\hline Restrictiveness of Migrant Integration Policies & $\begin{array}{c}-0.462^{* * *} \\
(0.049)\end{array}$ & $\begin{array}{c}-0.019^{* * *} \\
(0.002)\end{array}$ & $\begin{array}{c}-0.464^{* * *} \\
(0.056)\end{array}$ & $\begin{array}{c}-0.330^{* * *} \\
(0.063)\end{array}$ & $\begin{array}{c}-0.462^{* * *} \\
(0.060)\end{array}$ & $\begin{array}{c}-0.462^{* * * *} \\
(0.082)\end{array}$ & $\begin{array}{c}-0.449^{* * *} \\
(0.083)\end{array}$ & $\begin{array}{c}-0.470^{* * * *} \\
(0.052)\end{array}$ & $\begin{array}{c}-0.436^{* * * *} \\
(0.047)\end{array}$ & $\begin{array}{c}-0.496^{* * * *} \\
(0.057)\end{array}$ & $\begin{array}{c}-0.463 \\
(-0.491 ;-0.418)\end{array}$ \\
\hline Union Density & $\begin{array}{c}0.153^{* * * *} \\
(0.044)\end{array}$ & $\begin{array}{l}0.004^{* *} \\
(0.002)\end{array}$ & $\begin{array}{c}0.165 * * * \\
(0.033)\end{array}$ & $\begin{array}{l}0.084^{* *} \\
(0.041)\end{array}$ & $\begin{array}{c}0.153 * * * \\
(0.036)\end{array}$ & $\begin{array}{c}0.153^{* * * *} \\
(0.047)\end{array}$ & $\begin{array}{l}0.050 \\
(0.094)\end{array}$ & $\begin{array}{l}0.127^{* * *} \\
(0.046)\end{array}$ & $\begin{array}{c}0.156^{* * * *} \\
(0.042)\end{array}$ & $\begin{array}{l}0.116^{* *} \\
(0.046)\end{array}$ & $\begin{array}{c}0.151 \\
(0.114 ; 0.173)\end{array}$ \\
\hline Coordination of Wage-setting & $\begin{array}{c}0.700^{* * *} \\
(0.219)\end{array}$ & $\begin{array}{l}0.026^{* * *} \\
(0.010)\end{array}$ & $\begin{array}{c}0.675 * * * \\
(0.164)\end{array}$ & $\begin{array}{l}0.190 \\
(0.126)\end{array}$ & $\begin{array}{c}0.701 * * * \\
(0.177)\end{array}$ & $\begin{array}{c}0.701 * * * \\
(0.235)\end{array}$ & $\begin{array}{l}1.658^{* * *} \\
(0.444)\end{array}$ & $\begin{array}{c}0.640^{* * *} \\
(0.259)\end{array}$ & $\begin{array}{c}0.687^{* * * *} \\
(0.219)\end{array}$ & $\begin{array}{l}0.603^{* *} \\
(0.247)\end{array}$ & $\begin{array}{c}0.707 \\
(0.64 ; 0.771)\end{array}$ \\
\hline Public Spending on Early Childhood Education and Care & $\begin{array}{r}3.70 \\
(1 .\end{array}$ & $\begin{array}{c}0.250 * * * \\
(0.071)\end{array}$ & $\begin{array}{c}3.423 * * * \\
(0.622)\end{array}$ & $\begin{array}{c}2.151^{* * *} \\
(0.799)\end{array}$ & $\begin{array}{r}3.70 \\
(0.6\end{array}$ & $\begin{array}{c}3.708^{* * *} \\
(0.951)\end{array}$ & $\begin{array}{l}5.855^{* *} \\
(2.146)\end{array}$ & $\begin{array}{c}3.628^{* * *} \\
(1.295)\end{array}$ & $\begin{array}{c}3.670^{* * * *} \\
(1.177)\end{array}$ & $\begin{array}{c}3.709^{* * *} \\
(1.276)\end{array}$ & $\begin{array}{c}3.699 \\
(3.122 ; 4.285)\end{array}$ \\
\hline Share of Part-Time Employmes & $\begin{array}{c}0.946^{* * *} \\
(0.118)\end{array}$ & $\begin{array}{c}0.045^{* * *} \\
(0.006)\end{array}$ & $\begin{array}{c}0.932^{* * * *} \\
(0.066)\end{array}$ & $\begin{array}{c}0.735 * * * \\
(0.064)\end{array}$ & $\begin{array}{c}0.946 * * * \\
(0.073)\end{array}$ & $\begin{array}{c}0.946 * * * \\
(0.098)\end{array}$ & $\begin{array}{c}0.982^{2 * * *} \\
(0.168)\end{array}$ & $\begin{array}{c}0.943^{* * *} \\
(0.126)\end{array}$ & $\begin{array}{c}1.021^{* * * *} \\
(0.109)\end{array}$ & $\begin{array}{c}0.889 * * * \\
(0.104)\end{array}$ & $\begin{array}{c}0.956 \\
(0.868 ; 0.994)\end{array}$ \\
\hline Job-Protected Maternity Leave & $\begin{array}{c}0.025 * * * \\
(0.006)\end{array}$ & $\begin{array}{c}0.001 * * * \\
(0.000)\end{array}$ & $\begin{array}{c}0.026^{* * *} \\
(0.007)\end{array}$ & $\begin{array}{l}0.013 \\
(0.009)\end{array}$ & $\begin{array}{c}0.025^{* * *} \\
(0.008)\end{array}$ & $\begin{array}{c}0.025^{* * * *} \\
(0.009)\end{array}$ & $\begin{array}{c}0.087^{* * * *} \\
(0.011)\end{array}$ & $\begin{array}{c}0.024^{* * *} \\
(0.006)\end{array}$ & $\begin{array}{c}0.020^{* * * *} \\
(0.007)\end{array}$ & $\begin{array}{c}0.025^{* * *} \\
(0.006)\end{array}$ & $\begin{array}{c}0.024 \\
(0.021 ; 0.028)\end{array}$ \\
\hline & 48 & 4 & 40 & 489 & 48 & 489 & 11 & 44 & 511 & 44 & \\
\hline & 23 & 23 & 23 & 23 & $2:$ & 23 & $2:$ & $2:$ & 25 & 23 & \\
\hline ired & 0.887 & 0.870 & & 0.971 & 0.887 & 0.887 & 0.891 & 0.881 & 0.879 & 0.879 & \\
\hline
\end{tabular}

Source: Authors' calculations.
Notes: All specicications include country and year fixed effects. Column (1) reports the baseline estimation results; column (2) reports the results after applying the logistic transformation to the deKatz estimator; column (5) reports the estimates from a seemingly unrelated regressions (SUR) estimation of a 4-equation system (one for each group); column (4) shows the results using the Beckthe results with the Newey-West correction for the standard errors; column (7) shows the results based on a sample of 5-year averages; column (8) reports the results dropping global financial crisis (GFC) years 2008 and 2009 from the sample; column (9) reports the coefficients when the sample includes countries that became AEs after 1980; column (10) shows the results when the lag of the output gap is replaced with the lag of the unemployment rate; and column (11) reports the median coefficient from a distribution of estimates obtained by dropping one country at a time from the sample.
Driscoll-Kraay standard errors are reported in parentheses in columns (1), (2), (7)-(11); bootstrapped standard errors are reported in parentheses in column (3); HAC standard errors assuming a paneldependent correlation structure are reported in column (4). Column (11) reports the 10th and 90 th percentile of the estimated coefficients in parentheses. ${ }^{* * *}$, $* *$, and ${ }^{*}$ indicate statistical significance at 1,5 , and 10 percent, respectively. 
Table 7: Drivers of Older Worker (Ages 55 and Over) Labor Force Participation Rates, Robustness

\begin{tabular}{|c|c|c|c|c|c|c|c|c|c|c|c|}
\hline & Baseline & $\begin{array}{c}\text { Logistic } \\
\text { transfor- } \\
\text { mation }\end{array}$ & SUR & $\begin{array}{l}\text { Beck and } \\
\text { Katz }\end{array}$ & $\begin{array}{l}\text { HAC } \\
\text { standard } \\
\text { errors }\end{array}$ & $\begin{array}{l}\text { Newey- } \\
\text { West } \\
\text { standard } \\
\text { errors }\end{array}$ & $\begin{array}{c}5 \text {-year } \\
\text { averages }\end{array}$ & $\begin{array}{c}\text { Excluding } \\
\text { GFC }\end{array}$ & $\begin{array}{l}\text { Including } \\
\text { all AEs }\end{array}$ & $\begin{array}{c}\text { Replacing } \\
\text { output } \\
\text { gap with } \\
\text { unem- } \\
\text { ployment } \\
\text { rate } \\
(10) \\
\end{array}$ & $\begin{array}{l}\text { Dropping one } \\
\text { country at a } \\
\text { time }\end{array}$ \\
\hline Lag of Output Gap & $\begin{array}{r}-0.006 \\
(0.068)\end{array}$ & $\begin{array}{l}-0.000 \\
-(0.003)\end{array}$ & $\begin{array}{l}0.009 \\
0.056)\end{array}$ & 0.025 & $\begin{array}{l}-0.006 \\
(0.055)\end{array}$ & $\begin{array}{r}-0.006 \\
(0.083)\end{array}$ & 0.178 & $\begin{array}{l}0.003 \\
(0.078)\end{array}$ & 0.000 & $-0.268^{* * *}$ & $\begin{array}{c}-0.008 \\
(-0.045 \cdot 0.014)\end{array}$ \\
\hline Routinization*Relative Price of Investment & $\begin{array}{l}0.505^{*} \\
(0.288)\end{array}$ & $\begin{array}{l}0.009 \\
(0.015)\end{array}$ & $\begin{array}{c}1.033^{* * *} \\
(0.222)\end{array}$ & $\begin{array}{c}0.198 \\
(0.229)\end{array}$ & $\begin{array}{c}0.505^{* * *} \\
(0.184)\end{array}$ & $\begin{array}{l}0.505 \\
(0.372)\end{array}$ & $\begin{array}{c}0.473 \\
(0.298)\end{array}$ & $\begin{array}{l}0.468 \\
(0.292)\end{array}$ & $\begin{array}{c}0.742 * * * \\
(0.241)\end{array}$ & $\begin{array}{r}0.472 \\
(0.289)\end{array}$ & $\begin{array}{c}0.503 \\
(0.219 ; 0.593)\end{array}$ \\
\hline Lag of Trade Openness & $\begin{array}{c}-0.059 * * * \\
(0.009)\end{array}$ & $\begin{array}{c}-0.002^{* * *} \\
(0.000)\end{array}$ & $\begin{array}{c}-0.066^{* * * *} \\
(0.013)\end{array}$ & $\begin{array}{l}-0.012 \\
(0.008)\end{array}$ & $\begin{array}{c}-0.059^{* * *} \\
(0.013)\end{array}$ & $\begin{array}{c}-0.059^{* * *} \\
(0.014)\end{array}$ & $\begin{array}{c}-0.051^{* * * *} \\
(0.013)\end{array}$ & $\begin{array}{c}-0.063^{* * *} \\
(0.015)\end{array}$ & $\begin{array}{c}-0.045^{* * *} \\
(0.012)\end{array}$ & $\begin{array}{c}-0.063^{* * *} \\
(0.013)\end{array}$ & $\begin{array}{c}-0.06 \\
(-0.07 ;-0.044)\end{array}$ \\
\hline Relative Service Employment & $\begin{array}{r}0.009 \\
(0.006)\end{array}$ & $\begin{array}{c}0.000^{* * *} \\
(0.000)\end{array}$ & $\begin{array}{l}0.007 \\
(0.006)\end{array}$ & $\begin{array}{c}0.002 \\
(0.004)\end{array}$ & $\begin{array}{r}0.009 \\
(0.006)\end{array}$ & $\begin{array}{l}0.009 \\
(0.006)\end{array}$ & $\begin{array}{r}0.007 \\
(0.006)\end{array}$ & $\begin{array}{l}0.008 \\
(0.006)\end{array}$ & $\begin{array}{l}0.005 \\
(0.006)\end{array}$ & $\begin{array}{l}0.008 \\
(0.006)\end{array}$ & $\begin{array}{c}0.01 \\
(0.004 ; 0.014)\end{array}$ \\
\hline Lag of Urbanization & 0.194 & $\begin{array}{l}0.014^{* *} \\
(0.007)\end{array}$ & $\begin{array}{l}-0.056 \\
(0.084)\end{array}$ & $\begin{array}{l}0.118 \\
(0.092)\end{array}$ & $\begin{array}{l}0.194^{* * *} \\
(0.064)\end{array}$ & $\begin{array}{l}0.194^{*} \\
(0.114)\end{array}$ & $\begin{array}{l}0.138 \\
(0.172)\end{array}$ & $\begin{array}{l}0.225^{*} \\
(0.127)\end{array}$ & $0.189^{*}$ & $\begin{array}{l}0.223^{*} \\
(0.126)\end{array}$ & $\begin{array}{l}0.194 \\
(0.095 \cdot 0.245)\end{array}$ \\
\hline Education (\% Secondary) & $\begin{array}{l}0.038^{*} \\
(0.021)\end{array}$ & $\begin{array}{c}0.001 \\
(0.001)\end{array}$ & $\begin{array}{c}0.019 \\
(0.021)\end{array}$ & $\begin{array}{l}-0.016 \\
(0.021)\end{array}$ & $\begin{array}{l}0.038^{*} \\
(0.020)\end{array}$ & $\begin{array}{c}0.038 \\
(0.027)\end{array}$ & $\begin{array}{c}0.004 \\
(0.043)\end{array}$ & $\begin{array}{l}0.037^{*} \\
(0.022)\end{array}$ & $\begin{array}{c}0.053^{* *} \\
(0.020)\end{array}$ & $\begin{array}{l}0.037^{*} \\
(0.022)\end{array}$ & $\begin{array}{c}0.036 \\
(0.016 ; 0.059)\end{array}$ \\
\hline Education (\% Tertiary) & $\begin{array}{c}0.389^{* * * *} \\
(0.050)\end{array}$ & $\begin{array}{c}0.018^{* * *} \\
(0.002)\end{array}$ & $\begin{array}{c}0.321 * * * \\
(0.059)\end{array}$ & $\begin{array}{c}0.260^{* * *} \\
(0.057)\end{array}$ & $\begin{array}{c}0.389^{* * *} \\
(0.058)\end{array}$ & $\begin{array}{c}0.389^{* * *} \\
(0.093)\end{array}$ & $\begin{array}{l}0.296 * * \\
(0.085)\end{array}$ & $\begin{array}{c}0.384^{* * * *} \\
(0.053)\end{array}$ & $\begin{array}{c}0.397^{* * * *} \\
(0.046)\end{array}$ & $\begin{array}{c}0.386^{* * *} \\
(0.056)\end{array}$ & $\begin{array}{c}0.387 \\
(0.3 ; 0.44)\end{array}$ \\
\hline Tax wedge & $\begin{array}{c}-0.263^{* * *} \\
(0.037)\end{array}$ & $\begin{array}{c}-0.012^{* * *} \\
(0.002)\end{array}$ & $\begin{array}{c}-0.185^{* * *} \\
(0.035)\end{array}$ & $\begin{array}{c}-0.062^{* *} \\
(0.029)\end{array}$ & $\begin{array}{c}-0.263^{* * *} \\
(0.032)\end{array}$ & $\begin{array}{c}-0.263^{* * *} \\
(0.049)\end{array}$ & $\begin{array}{c}-0.332^{* * * *} \\
(0.070)\end{array}$ & $\begin{array}{c}-0.255^{* * *} \\
(0.039)\end{array}$ & $\begin{array}{c}-0.245^{* * *} \\
(0.040)\end{array}$ & $\begin{array}{c}-0.255^{* * *} \\
(0.040)\end{array}$ & $\begin{array}{c}-0.268 \\
(-0.288 ;-0.208)\end{array}$ \\
\hline Unemployment Replacement Ratio & $\begin{array}{l}-0.081 \\
(0.050)\end{array}$ & $\begin{array}{c}-0.006 * * \\
(0.002)\end{array}$ & $\begin{array}{l}-0.036 \\
(0.029)\end{array}$ & $\begin{array}{r}-0.039 \\
(0.024)\end{array}$ & $\begin{array}{c}-0.081^{* * * *} \\
(0.029)\end{array}$ & $\begin{array}{c}-0.081^{*} \\
(0.043)\end{array}$ & $\begin{array}{l}-0.073 \\
(0.052)\end{array}$ & $\begin{array}{l}-0.051 \\
(0.049)\end{array}$ & $\begin{array}{l}-0.079 \\
(0.052)\end{array}$ & $\begin{array}{l}-0.051 \\
0.047)\end{array}$ & $\begin{array}{c}-0.08 \\
(-0.088 \cdot-0.042)\end{array}$ \\
\hline Public Spending on ALMP & $\begin{array}{c}-0.025^{* *} \\
(0.009)\end{array}$ & $\begin{array}{l}-0.001 \\
(0.001)\end{array}$ & $\begin{array}{c}-0.024^{* *} \\
(0.010)\end{array}$ & $\begin{array}{l}-0.003 \\
(0.008)\end{array}$ & $\begin{array}{c}-0.025^{* *} \\
(0.010)\end{array}$ & $\begin{array}{c}-0.025 * * \\
(0.012)\end{array}$ & $\begin{array}{c}-0.039^{* *} \\
(0.012)\end{array}$ & $\begin{array}{c}-0.026^{* *} \\
(0.010)\end{array}$ & $\begin{array}{c}-0.027^{* * *} \\
(0.010)\end{array}$ & $\begin{array}{c}-0.027^{* * *} \\
(0.009)\end{array}$ & $\begin{array}{c}-0.025 \\
(-0.029 ;-0.018)\end{array}$ \\
\hline Restrictiveness of Migrant Integration Policies & $\begin{array}{l}0.056 \\
(0.088)\end{array}$ & $\begin{array}{l}0.001 \\
(0.005)\end{array}$ & $\begin{array}{l}0.131^{*} \\
(0.068)\end{array}$ & $\begin{array}{l}0.066 \\
(0.058)\end{array}$ & $\begin{array}{l}0.056 \\
(0.069)\end{array}$ & $\begin{array}{l}0.056 \\
(0.092)\end{array}$ & $\begin{array}{l}0.126 \\
(0.132)\end{array}$ & $\begin{array}{l}0.063 \\
(0.087)\end{array}$ & $\begin{array}{l}0.108 \\
(0.092)\end{array}$ & $\begin{array}{l}0.063 \\
(0.084)\end{array}$ & $\begin{array}{c}0.055 \\
(-0.024 ; 0.11)\end{array}$ \\
\hline Union Density & $\begin{array}{c}-0.115^{* * *} \\
(0.032)\end{array}$ & $\begin{array}{c}-0.006^{* * *} \\
(0.002)\end{array}$ & $\begin{array}{c}-0.126^{* * *} \\
(0.036)\end{array}$ & $\begin{array}{c}-0.118^{* * * *} \\
(0.031)\end{array}$ & $\begin{array}{c}-0.115^{* * * *} \\
(0.032)\end{array}$ & $\begin{array}{c}-0.115^{* * * *} \\
(0.038)\end{array}$ & $\begin{array}{l}-0.077 \\
(0.052)\end{array}$ & $\begin{array}{c}-0.127^{* * *} \\
(0.038)\end{array}$ & $\begin{array}{c}-0.125^{* * *} \\
(0.026)\end{array}$ & $\begin{array}{c}-0.125^{* * *} \\
(0.036)\end{array}$ & $\begin{array}{c}-0.114 \\
(-0.146 ;-0.096)\end{array}$ \\
\hline Coordination of Wage-setting & $\begin{array}{l}0.040 \\
(0.222)\end{array}$ & $\begin{array}{c}0.010 \\
(0.011)\end{array}$ & $\begin{array}{r}-0.016 \\
-0.185)\end{array}$ & $\begin{array}{c}0.102 \\
(0.078)\end{array}$ & $\begin{array}{l}0.040 \\
(0.173)\end{array}$ & $\begin{array}{r}0.040 \\
(0.214)\end{array}$ & $\begin{array}{l}0.803^{*} \\
(0.363)\end{array}$ & $\begin{array}{c}0.109 \\
0.299\end{array}$ & $\begin{array}{l}0.106 \\
(0.231)\end{array}$ & $\begin{array}{l}0.088 \\
(0.246)\end{array}$ & $\begin{array}{c}0.029 \\
(-0.066: 0.111)\end{array}$ \\
\hline Statutory Retirement Age & $\begin{array}{c}0.661^{* * *} \\
(0.174)\end{array}$ & $\begin{array}{c}0.035^{* * * *} \\
(0.010)\end{array}$ & $\begin{array}{c}0.677^{* * *} \\
(0.196)\end{array}$ & $\begin{array}{l}0.495^{* *} \\
(0.209)\end{array}$ & $\begin{array}{c}0.661^{* * * *} \\
(0.204)\end{array}$ & $\begin{array}{l}0.661^{* *} \\
(0.321)\end{array}$ & $\begin{array}{c}0.505 \\
(0.308)\end{array}$ & $\begin{array}{c}0.591^{* * *} \\
(0.178)\end{array}$ & $\begin{array}{c}0.943^{* * * *} \\
(0.204)\end{array}$ & $\begin{array}{c}0.594^{* * *} \\
(0.179)\end{array}$ & $\begin{array}{c}0.658 \\
(0.456 ; 0.815)\end{array}$ \\
\hline Public Spending on Old-Age Pension & $\begin{array}{c}-0.750^{* * * *} \\
(0.154)\end{array}$ & $\begin{array}{c}-0.038^{* * *} \\
(0.009)\end{array}$ & $\begin{array}{c}-0.597^{* * *} \\
(0.196)\end{array}$ & $\begin{array}{c}-0.306^{* *} \\
(0.126)\end{array}$ & $\begin{array}{c}-0.750^{* * *} \\
(0.176)\end{array}$ & $\begin{array}{c}-0.750^{* * *} \\
(0.255)\end{array}$ & $\begin{array}{c}-0.873^{* * *} \\
(0.095)\end{array}$ & $\begin{array}{c}-0.826^{* * * *} \\
(0.152)\end{array}$ & $\begin{array}{c}-0.596 * * * * \\
(0.161)\end{array}$ & $\begin{array}{c}-0.840^{* * *} \\
(0.179)\end{array}$ & $\begin{array}{c}-0.749 \\
(-0.839 ;-0.566)\end{array}$ \\
\hline Public Spending on Incapacity & $\begin{array}{c}-0.421 * * * \\
(0.562)\end{array}$ & $\begin{array}{l}-0.025 \\
(0.031)\end{array}$ & $\begin{array}{c}-0.689^{* * *} \\
(0.348)\end{array}$ & $\begin{array}{l}-0.008 \\
(0.300)\end{array}$ & $\begin{array}{l}-0.421 \\
(0.295)\end{array}$ & $\begin{array}{l}-0.421 \\
(0.404)\end{array}$ & $\begin{array}{l}-0.659 \\
(0.831)\end{array}$ & $\begin{array}{l}-0.208 \\
(0.586)\end{array}$ & $\begin{array}{l}-0.320 \\
(0.570)\end{array}$ & $\begin{array}{l}-0.203 \\
(0.584)\end{array}$ & $\begin{array}{c}-0.426 \\
(-0.634 ;-0.163)\end{array}$ \\
\hline & 489 & 56 & 489 & 56 & $x$ & $x$ & 13 & 52 & $x$ & 522 & \\
\hline & & & 23 & & & & & & & & \\
\hline$R-\mathrm{s}$ & 0.887 & 0.681 & & 0.925 & 686 & 0.686 & 0.737 & 665 & 0.690 & 0.666 & \\
\hline
\end{tabular}

Source: Authors' calculations.

Notes: All specifications include country and year fixed effects. Column (1) reports the baseline estimation results; column (2) reports the results after applying the logistic transformation to the dependent variable; column (3) reports the estimates from a seemingly unrelated regressions (SUR) estimation of a 4-equation system (one for each group); column (4) shows the results using the Beck-Katz estimator; column (5) reports the estimates with heteroskedasticity and autocorrelation consistent (HAC) standard errors, without the correction for cross-sectional dependence, global financial crisis (GFC) years 2008 and 2009 from the sample; column (9) reports the coefficients when the sample includes countries that became AEs after 1980; column (10) shows the results when the lag of the output gap is replaced with the lag of the unemployment rate; and column (11) reports the median coefficient from a distribution of estimates obtained by dropping one country at a time from the sample. Driscoll-Kraay standard errors are reported in parentheses in columns (1),(2), (7)-(11); bootstrapped standard errors are reported in parentheses in column (3); HAC standard errors assuming a panel-dependent correlation structure are reported in column (4). Column (11) reports the 10th and 90th percentile of the estimated coefficients in parentheses. $* * * * *$, and $*$ indicate statistical significance at 1,5 , and 10 percent, respectivel, 
Table 8: Drivers of Aggregate Labor Force Participation Rates, Robustness

\begin{tabular}{|c|c|c|c|c|c|c|c|c|c|c|}
\hline & Baseline & $\begin{array}{c}\text { Logistic } \\
\text { transfor- } \\
\text { mation }\end{array}$ & $\begin{array}{c}\text { Beck and } \\
\text { Katz }\end{array}$ & $\begin{array}{l}\text { HAC } \\
\text { standard } \\
\text { errors }\end{array}$ & $\begin{array}{l}\text { Newey- } \\
\text { West } \\
\text { standard } \\
\text { errors }\end{array}$ & $\begin{array}{c}\text { 5-year } \\
\text { averages }\end{array}$ & $\begin{array}{c}\text { Excluding } \\
\text { GFC }\end{array}$ & $\begin{array}{l}\text { Including } \\
\text { all AEs }\end{array}$ & $\begin{array}{c}\text { Replacing } \\
\text { output } \\
\text { gap with } \\
\text { unem- } \\
\text { ployment } \\
\text { rate } \\
(9) \\
\end{array}$ & $\begin{array}{l}\text { Dropping one } \\
\text { country at a } \\
\text { time }\end{array}$ \\
\hline Lag of Output Gap & $\begin{array}{c}0.183^{* * *} \\
(0.044)\end{array}$ & $\begin{array}{c}0.008^{* * *} \\
(0.002)\end{array}$ & $\begin{array}{c}0.090^{* * * *} \\
(0.025)\end{array}$ & $\begin{array}{c}0.183^{* * *} \\
(0.036)\end{array}$ & $\begin{array}{c}0.183^{* * *} \\
(0.042)\end{array}$ & $\begin{array}{c}0.250^{* *} \\
(0.096)\end{array}$ & $\begin{array}{c}0.193^{* * *} \\
(0.045)\end{array}$ & $\begin{array}{c}0.136^{* * *} \\
(0.039)\end{array}$ & $\begin{array}{c}-0.364^{* * * *} \\
(0.037)\end{array}$ & $\begin{array}{c}0.182 \\
(0.143 ; 0.2)\end{array}$ \\
\hline Routinization*Relative Price of Investment & $\begin{array}{c}0.536^{* * * *} \\
(0.175)\end{array}$ & $\begin{array}{c}0.022^{* * * *} \\
(0.007)\end{array}$ & $\begin{array}{c}0.272^{* * *} \\
(0.120)\end{array}$ & $\begin{array}{c}0.536^{* * * *} \\
(0.118)\end{array}$ & $\begin{array}{c}0.536^{* * * *} \\
(0.138)\end{array}$ & $\begin{array}{l}0.552^{*} \\
(0.247)\end{array}$ & $\begin{array}{c}0.506^{* * * *} \\
(0.167)\end{array}$ & $\begin{array}{c}0.653^{* * * *} \\
(0.156)\end{array}$ & $\begin{array}{c}0.548 * * * \\
(0.153)\end{array}$ & $\begin{array}{c}0.533 \\
(0.459 ; 0.61)\end{array}$ \\
\hline Lag of Trade Openness & $\begin{array}{l}0.012^{*} \\
(0.007)\end{array}$ & $\begin{array}{c}0.000 \\
(0.000)\end{array}$ & $\begin{array}{c}0.003 \\
(0.007)\end{array}$ & $\begin{array}{c}0.012 \\
(0.009)\end{array}$ & $\begin{array}{c}0.012 \\
(0.010)\end{array}$ & $\begin{array}{c}0.016 \\
(0.011)\end{array}$ & $\begin{array}{l}0.020^{* *} \\
(0.008)\end{array}$ & $\begin{array}{c}0.003 \\
(0.007)\end{array}$ & $\begin{array}{c}0.004 \\
(0.007)\end{array}$ & $\begin{array}{c}0.013 \\
(0.003 ; 0.016)\end{array}$ \\
\hline Relative Service Employment & $\begin{array}{l}0.010^{* * *} \\
(0.004)\end{array}$ & $\begin{array}{l}0.000^{* *} \\
(0.000)\end{array}$ & $\begin{array}{c}0.002 \\
(0.003)\end{array}$ & $\begin{array}{c}0.010^{* * *} \\
(0.004)\end{array}$ & $\begin{array}{c}0.010^{* * *} \\
(0.005)\end{array}$ & $\begin{array}{c}0.0166^{* * *} \\
(0.004)\end{array}$ & $\begin{array}{l}0.010^{* *} \\
(0.004)\end{array}$ & $\begin{array}{c}0.013^{* * * *} \\
(0.004)\end{array}$ & $\begin{array}{c}0.016^{* * * *} \\
(0.004)\end{array}$ & $\begin{array}{c}0.011 \\
(0.006 ; 0.012)\end{array}$ \\
\hline Lag of Urbanization & $\begin{array}{c}0.249^{* * * *} \\
(0.047)\end{array}$ & $\begin{array}{c}0.011^{* * * *} \\
(0.002)\end{array}$ & $\begin{array}{c}0.208^{* * * *} \\
(0.042)\end{array}$ & $\begin{array}{c}0.249^{* * *} \\
(0.039)\end{array}$ & $\begin{array}{c}0.249^{* * * *} \\
(0.071)\end{array}$ & $\begin{array}{c}0.240^{* * * *} \\
(0.047)\end{array}$ & $\begin{array}{c}0.260^{* * *} \\
(0.056)\end{array}$ & $\begin{array}{c}0.257^{* * * *} \\
(0.045)\end{array}$ & $\begin{array}{c}0.268 * * * \\
(0.063)\end{array}$ & $\begin{array}{c}0.25 \\
(0.202 ; 0.294)\end{array}$ \\
\hline Education (\% Secondary) & $\begin{array}{c}0.063^{* * * *} \\
(0.017)\end{array}$ & $\begin{array}{c}0.003^{* * * *} \\
(0.001)\end{array}$ & $\begin{array}{c}0.018 \\
(0.014)\end{array}$ & $\begin{array}{c}0.063^{* * * *} \\
(0.015)\end{array}$ & $\begin{array}{c}0.063^{* * * *} \\
(0.017)\end{array}$ & $\begin{array}{c}0.058^{* *} \\
(0.017)\end{array}$ & $\begin{array}{c}0.061^{* * * *} \\
(0.019)\end{array}$ & $\begin{array}{c}0.062^{* * * *} \\
(0.016)\end{array}$ & $\begin{array}{c}0.066^{* * * *} \\
(0.017)\end{array}$ & $\begin{array}{c}0.064 \\
(0.047 ; 0.074)\end{array}$ \\
\hline Education (\% Tertiary) & $\begin{array}{c}0.1355^{* * *} \\
(0.031)\end{array}$ & $\begin{array}{c}0.006^{* * * *} \\
(0.001)\end{array}$ & $\begin{array}{c}0.108^{* * * *} \\
(0.027)\end{array}$ & $\begin{array}{c}0.135^{* * *} \\
(0.032)\end{array}$ & $\begin{array}{c}0.135^{* * * *} \\
(0.035)\end{array}$ & $\begin{array}{c}0.121^{* *} \\
(0.034)\end{array}$ & $\begin{array}{c}0.115^{* * * *} \\
(0.029)\end{array}$ & $\begin{array}{c}0.136^{* * *} \\
(0.031)\end{array}$ & $\begin{array}{c}0.060^{* *} \\
(0.026)\end{array}$ & $\begin{array}{c}0.134 \\
(0.119 ; 0.158)\end{array}$ \\
\hline Tax wedge & $\begin{array}{c}-0.240^{* * * *} \\
(0.026)\end{array}$ & $\begin{array}{c}-0.010^{* * * *} \\
(0.001)\end{array}$ & $\begin{array}{c}-0.073^{* * * *} \\
(0.020)\end{array}$ & $\begin{array}{c}-0.240^{* * * *} \\
(0.021)\end{array}$ & $\begin{array}{c}-0.240^{* * * *} \\
(0.027)\end{array}$ & $\begin{array}{c}-0.275^{* * *} \\
(0.029)\end{array}$ & $\begin{array}{c}-0.223^{* * *} \\
(0.024)\end{array}$ & $\begin{array}{c}-0.226 * * * \\
(0.025)\end{array}$ & $\begin{array}{c}-0.125^{* * * *} \\
(0.030)\end{array}$ & $\begin{array}{c}-0.242 \\
(-0.253 ;-0.216)\end{array}$ \\
\hline Unemployment Replacement Ratio & $\begin{array}{c}-0.078^{* * * *} \\
(0.025)\end{array}$ & $\begin{array}{c}-0.003^{* * * *} \\
(0.001)\end{array}$ & $\begin{array}{c}-0.032 * * \\
(0.013)\end{array}$ & $\begin{array}{c}-0.078^{* * * *} \\
(0.017)\end{array}$ & $\begin{array}{c}-0.078^{* * * *} \\
(0.028)\end{array}$ & $\begin{array}{c}-0.083^{*} \\
(0.041)\end{array}$ & $\begin{array}{c}-0.068^{* *} \\
(0.025)\end{array}$ & $\begin{array}{c}-0.076^{* * *} \\
(0.024)\end{array}$ & $\begin{array}{c}-0.069^{* * * *} \\
(0.023)\end{array}$ & $\begin{array}{c}-0.076 \\
(-0.085 ;-0.067)\end{array}$ \\
\hline Public Spending on ALMP & $\begin{array}{c}0.0311^{* * *} \\
(0.007)\end{array}$ & $\begin{array}{c}0.001 * * * \\
(0.000)\end{array}$ & $\begin{array}{c}0.017^{* * * *} \\
(0.006)\end{array}$ & $\begin{array}{c}0.031^{* * *} \\
(0.006)\end{array}$ & $\begin{array}{c}0.031^{* * *} \\
(0.009)\end{array}$ & $\begin{array}{c}0.034^{* *} \\
(0.013)\end{array}$ & $\begin{array}{c}0.030^{* * *} \\
(0.007)\end{array}$ & $\begin{array}{c}0.033^{* * * *} \\
(0.007)\end{array}$ & $\begin{array}{l}0.015^{*} \\
(0.008)\end{array}$ & $\begin{array}{c}0.031 \\
(0.024 ; 0.034)\end{array}$ \\
\hline Restrictiveness of Migrant Integration Policies & $\begin{array}{c}-0.207^{* * * *} \\
(0.049)\end{array}$ & $\begin{array}{c}-0.008^{* * * *} \\
(0.002)\end{array}$ & $\begin{array}{c}-0.084^{* *} \\
(0.038)\end{array}$ & $\begin{array}{c}-0.207 * * * \\
(0.040)\end{array}$ & $\begin{array}{c}-0.207 * * * \\
(0.070)\end{array}$ & $\begin{array}{c}-0.245^{* * *} \\
(0.055)\end{array}$ & $\begin{array}{c}-0.191^{* * *} \\
(0.054)\end{array}$ & $\begin{array}{c}-0.198^{* * *} \\
(0.047)\end{array}$ & $\begin{array}{c}-0.230^{* * * *} \\
(0.052)\end{array}$ & $\begin{array}{c}-0.211 \\
(-0.255 ;-0.184)\end{array}$ \\
\hline Union Density & $\begin{array}{l}-0.015 \\
(0.025)\end{array}$ & $\begin{array}{l}-0.001 \\
(0.001)\end{array}$ & $\begin{array}{c}-0.064^{* * *} \\
(0.018)\end{array}$ & $\begin{array}{l}-0.015 \\
(0.021)\end{array}$ & $\begin{array}{l}-0.015 \\
(0.031)\end{array}$ & $\begin{array}{c}0.021 \\
(0.024)\end{array}$ & $\begin{array}{l}-0.030 \\
(0.025)\end{array}$ & $\begin{array}{l}-0.007 \\
(0.023)\end{array}$ & $\begin{array}{l}-0.004 \\
(0.022)\end{array}$ & $\begin{array}{c}-0.016 \\
(-0.033 ;-0.001)\end{array}$ \\
\hline Coordination of Wage-setting & $\begin{array}{l}0.256^{* *} \\
(0.120)\end{array}$ & $\begin{array}{c}0.011^{* *} \\
(0.005)\end{array}$ & $\begin{array}{c}0.020 \\
(0.065)\end{array}$ & $\begin{array}{c}0.256^{* *} \\
(0.112)\end{array}$ & $\begin{array}{l}0.256^{*} \\
(0.148)\end{array}$ & $\begin{array}{c}0.289 \\
(0.302)\end{array}$ & $\begin{array}{c}0.274^{* *} \\
(0.108)\end{array}$ & $\begin{array}{l}0.238^{*} \\
(0.121)\end{array}$ & $\begin{array}{l}-0.027 \\
(0.115)\end{array}$ & $\begin{array}{c}0.26 \\
(0.203 ; 0.312)\end{array}$ \\
\hline & 57 & 5 & 5 & 570 & 57 & 1 & 5 & 592 & 524 & \\
\hline & 23 & 23 & 23 & 23 & 23 & 23 & 23 & 25 & 23 & \\
\hline$R$-squared & 0.578 & 0.569 & 0.983 & 0.578 & 0.578 & 0.596 & 0.560 & 0.567 & 0.602 & \\
\hline
\end{tabular}

Source: Authors' calculations.
Notes: All specifications include country and year fixed effects. Column (1) reports the baseline estimation results; column (2) reports the results after applying the logistic transformation to the dependent variable; column (3) shows the results using the Beck-Katz estimator; column (4) reports the estimates with heteroskedasticity and autocorrelation consistent (HAC) standard errors, without the correction for cross-sectional dependence; column (5) shows the results with the Newey-West correction for the standard errors; column (6) shows the results based on a sample of 5-year averages; column (7) reports the results dropping global financial crisis (GFC) years 2008 and 2009 from the sample; column (8) reports the coefficients when the sample includes countries that became AEs after 1980; column (9) shows the results when the lag of the output gap is replaced with the lag of the unemployment rate; and column (10) reports the median coefficient from a distribution of estimates obtained by dropping one country at a time from the sample. Driscoll-Kraay standard errors are reported in parentheses in columns (1),(2), (6)-(9); HAC standard errors assuming a panel-dependent correlation structure are reported in column (3); heteroskedasticity and autocorrelation robust standard errors are reported in parentheses in column (4); and Newey-West corrected standard errors are reported in column (5). Column (10) reports the 10 th and 90 th percentile of the estimated coefficients in parentheses. ${ }^{* * *}, * *$, and $*$ indicate statistical significance at 1,5 , and 10 percent, respectively. 
With respect to the estimations on individual-level data, as the baseline specification does not control for income due to data limitations and endogeneity concerns, we include the income decile of employed individuals and the predicted income decile (based on age, gender, education, location, immigration status, and sector and occupation of last employment) for inactive individuals (for whom income information is not available) as a robustness checks. Results are generally robust, as shown in Table 9. Once a (predicted) income decile is included, the effect of being part of a couple and having children on the participation of women turns positive, the effect of other employed adults in the household turns negative, and income itself has a negative effect. This suggests that individuals in upper deciles may be able to afford to drop out of the labor force. The results on vulnerability to routinization and education are very similar to those in the baseline. Results are also robust to including interacted country-year fixed effects in addition to regionfixed effects to control for all possible country-year specific shocks, such as cyclical developments, changes in policies that affect all workers within a particular age-gender groups, and the like.

\section{Conclusions}

Recent and projected demographic trends are particularly concerning for AEs. Slowing population growth matched with rising life expectancy are already weighing on labor supply in several economies and could lead to very significant declines in participation rates as documented in Grigoli et al. (2018). However, there are striking differences in the evolution of labor force participation across countries, and even more across groups of workers. While the heterogeneous timing and pace of the demographic transition can explain part of the divergent trends, other factors, including policies and differential exposure to the global forces of technological progress, are also at play.

The findings of this paper suggest that many countries so far successfully counteracted the negative forces of aging on aggregate labor force participation by strengthening the attachment of specific groups of workers to the labor force. Changes in labor market policies and institutions, together with structural changes and gains in educational attainment, account for the bulk of the increase in the labor force attachment of prime-age women and older workers in the past three decades. Conversely, technological advances, namely automation, while beneficial for the economy as a whole, weighed on labor supply of most groups of workers, and can partially explain declining prime-age male participation. Individual-level evidence confirms the significant impact of vulnerability to routinization, and that detachment from the labor force is significantly more likely among individuals whose current or past occupations are more vulnerable to automation. But encouragingly, higher spending on education and active labor market programs, and access to more diverse labor markets, tend to attenuate this negative effect, at least for prime-age workers.

Looking forward, further investment in education, training, and activation policies can not only encourage individuals to be active in the labor market but also make the workforce more resilient to global developments, such as technological progress or globalization, that may obviate the need for certain skills. Also, policies that reduce disincentives for joining or remaining in the labor force and policies that help workers combine family and work life can broaden these gains by enabling people who are willing to work to do so. Finally, unless technology delivers offsetting productivity gains, these findings highlight the need for many AEs to rethink immigration policies to boost their labor supply, alongside policies encouraging older workers to postpone retirement. Although receiving migrants can pose challenges, potentially prompting a political backlash, it can also be a boon for host countries, including through its effects on population growth. 
Table 9: Determinants of Being in the Labor Force, Robustness

\begin{tabular}{|c|c|c|c|}
\hline & $\begin{array}{c}\text { Men, } \\
\text { ages } 25-54 \\
(1)\end{array}$ & $\begin{array}{c}\text { Women, } \\
\text { ages } 25-54 \\
(2)\end{array}$ & $\begin{array}{c}\text { All, } \\
\text { ages 55+ } \\
(3)\end{array}$ \\
\hline Age & $\begin{array}{c}1.261^{* * *} \\
(0.018)\end{array}$ & $\begin{array}{c}1.347^{* * *} \\
(0.021)\end{array}$ & $\begin{array}{c}1.356^{* * *} \\
(0.151)\end{array}$ \\
\hline Age Squared & $\begin{array}{c}0.997^{* * *} \\
(0.000)\end{array}$ & $\begin{array}{c}0.997^{* * *} \\
(0.000)\end{array}$ & $\begin{array}{c}0.998^{* * *} \\
(0.001)\end{array}$ \\
\hline Male & & & $\begin{array}{c}1.539^{* * * *} \\
(0.046)\end{array}$ \\
\hline Upper Secondary Education & $\begin{array}{c}1.737^{* * *} * \\
(0.056)\end{array}$ & $\begin{array}{c}1.855^{* * *} \\
(0.060)\end{array}$ & $\begin{array}{c}1.102^{* *} \\
(0.046)\end{array}$ \\
\hline Tertiary Education & $\begin{array}{c}2.217^{* * *} \\
(0.096)\end{array}$ & $\begin{array}{c}2.763^{* * *} \\
(0.115)\end{array}$ & $\begin{array}{c}1.240^{* * *} \\
(0.062)\end{array}$ \\
\hline Born in Country & $\begin{array}{c}1.761^{* * *} * \\
(0.051)\end{array}$ & $\begin{array}{c}1.520^{* * * *} \\
(0.050)\end{array}$ & $\begin{array}{c}1.167^{* *} \\
(0.075)\end{array}$ \\
\hline Urban & $\begin{array}{c}0.896^{* * *} \\
(0.027)\end{array}$ & $\begin{array}{c}0.864^{* * *} \\
(0.022)\end{array}$ & $\begin{array}{c}0.866^{* * *} \\
(0.037)\end{array}$ \\
\hline Number of Children in Household & $\begin{array}{c}1.094^{* * *} \\
(0.012)\end{array}$ & $\begin{array}{c}0.869^{* * * *} \\
(0.012)\end{array}$ & $\begin{array}{l}1.039 \\
(0.035)\end{array}$ \\
\hline One Adult with Children & $\begin{array}{c}1.045 \\
(0.087)\end{array}$ & $\begin{array}{c}0.846^{* * *} \\
(0.039)\end{array}$ & $\begin{array}{c}1.217 \\
(0.330)\end{array}$ \\
\hline Couple without Children & $\begin{array}{c}1.757^{* * *} * \\
(0.083)\end{array}$ & $\begin{array}{c}1.741^{* * *} \\
(0.128)\end{array}$ & $\begin{array}{c}1.161^{* * *} * \\
(0.051)\end{array}$ \\
\hline Couple with Children & $\begin{array}{c}2.141^{* * *} \\
(0.114)\end{array}$ & $\begin{array}{c}1.248^{* * *} \\
(0.088)\end{array}$ & $\begin{array}{c}2.429^{* * *} \\
(0.350)\end{array}$ \\
\hline Other Household Structure & $\begin{array}{c}1.212^{* * *} \\
(0.063)\end{array}$ & $\begin{array}{c}1.334^{* * *} \\
(0.092)\end{array}$ & $\begin{array}{c}1.726^{* * *} \\
(0.138)\end{array}$ \\
\hline Other Employed Adult(s) in Household & $\begin{array}{c}0.992 \\
(0.043)\end{array}$ & $\begin{array}{c}0.601^{* * * *} \\
(0.046)\end{array}$ & $\begin{array}{c}0.636^{* * * *} \\
(0.079)\end{array}$ \\
\hline RTI Score of Occupation & $\begin{array}{c}0.467^{* * *} * \\
(0.012)\end{array}$ & $\begin{array}{c}0.490^{* * *} \\
(0.012)\end{array}$ & $\begin{array}{c}0.488^{* * *} \\
(0.016)\end{array}$ \\
\hline Lagged Output Gap & $\begin{array}{c}1.042^{* * *} \\
(0.008)\end{array}$ & $\begin{array}{c}1.030^{* * *} \\
(0.008)\end{array}$ & $\begin{array}{c}1.037^{* * *} * \\
(0.012)\end{array}$ \\
\hline Predicted Income Decile & $\begin{array}{c}0.952^{* * *} \\
(0.001)\end{array}$ & $\begin{array}{c}0.950^{* * *} \\
(0.001)\end{array}$ & $\begin{array}{c}0.952^{* * *} \\
(0.002)\end{array}$ \\
\hline Number of Observations & 474,434 & 443,687 & 63,982 \\
\hline \multicolumn{4}{|c|}{$\begin{array}{l}\text { Source: Authors' calculations. } \\
\text { Notes: Logit regressions are based on a random sample of } 10,000 \text { respondents a } \\
\text { country a year of } 19 \text { countries. The table reports exponentiated coefficients. All } \\
\text { specifications include country, region, and year fixed effects. The base category for } \\
\text { education is "up to lower secondary education", for family composition the base cat- } \\
\text { egory is "one adult without children". Standard errors clustered at the country-year } \\
\text { level. Predicted income decile uses the actual income decile for those currently em- } \\
\text { ployed, and predicts the income decile for those currently unemployed/inactive us- } \\
\text { ing age, gender, education, migration status, location, sector, occupation and coun- } \\
\text { try, region and year fixed effects.***, **, and * indicate statistical significance at } 1 \text {, } \\
5 \text {, and } 10 \text { percent, respectively. }\end{array}$} \\
\hline
\end{tabular}




\section{References}

Abraham, Katharine G and Melissa S Kearney (2018). "Explaining the Decline in the US Employmentto-Population Ratio: A Review of the Evidence". In: National Bureau of Economic Research Working Paper No. 24333.

Acemoglu, Daron and David Autor (2011). "Skills, Tasks and Technologies: Implications for Employment and Earnings". In: Handbook of Labor Economics. Vol. 4. Elsevier, pp. 1043-1171.

Acemoglu, Daron and Pascual Restrepo (2017). "Robots and Jobs: Evidence from US Labor Markets". In: National Bureau of Economic Research Working Paper No. 23285.

Aguiar, Mark, Mark Bils, Kerwin Kofi Charles, and Erik Hurst (2017). "Leisure Luxuries and the Labor Supply of Young Men". In: National Bureau of Economic Research Working Paper No. 23552.

Aiyar, Shekhar, Bergljot Bjørnson Barkbu, Nicoletta Batini, Helge Berger, Enrica Detragiache, Allan Dizioli, Christian Ebeke, Huidan Lin, Linda Kaltani, Sebastian Sosa, Antonio Spilimbergo, and Petia Topalova (2016). "The Refugee Surge in Europe". In: International Monetary Fund, Staff Discussion Note 16/02.

Arulampalam, Wiji, Alison L Booth, and Mark P Taylor (2000). "Unemployment Persistence". In: Oxford Economic Papers 52.1, pp. 24-50.

Arulampalam, Wiji, Paul Gregg, and Mary Gregory (2001). "Unemployment Scarring". In: The Economic Journal 111.475, pp. 577-584.

Autor, David H and David Dorn (2013). "The Growth of Low-Skill Service Jobs and the Polarization of the US Labor Market". In: American Economic Review 103.5, pp. 1553-97.

Autor, David H, David Dorn, and Gordon H Hanson (2016). "The China Syndrome: Local Labor Market Effects of Import Competition in the United States". In: American Economic Review 103, pp. 2021-68.

Banerji, Angana, Ms Hannah Huidan Lin, and Mr Sergejs Saksonovs (2015). "Youth Unemployment in Advanced Europe: Okun's Law and Beyond". In: International Monetary Fund Working Paper 16/160.

Baron-Cohen, Simon, Rebecca C Knickmeyer, and Matthew K Belmonte (2005). "Sex Differences in the Brain: Implications for Explaining Autism". In: Science 310.5749, pp. 819-823.

Bassanini, Andrea and Romain Duval (2006). "Employment Patterns in OECD Countries". In: OECD Economic Department Working Paper 486, Organisation for Economic Co-operation and Development, Paris, France.

- (2009). "Unemployment, Institutions, and Reform Complementarities: Re-assessing the Aggregate Evidence for OECD Countries". In: Oxford Review of Economic Policy 25.1, pp. 40-59.

Bertola, Giuseppe, Francine D Blau, and Lawrence M Kahn (2007). "Labor Market Institutions and Demographic Employment Patterns". In: Journal of Population Economics 20.4, pp. 833867.

Blanchard, Olivier and Justin Wolfers (2000). "The Role of Shocks and Institutions in the Rise of European Unemployment: The Aggregate Evidence". In: The Economic Journal 110.462, pp. 1-33.

Blau, David M and Ryan M Goodstein (2010). "Can Social Security Explain Trends in Labor Force Participation of Older Men in the United States?" In: Journal of Human Resources 45.2, pp. 328-363.

Blau, Francine D and Lawrence M Kahn (2013). "Female Labor Supply: Why Is the United States Falling Behind?" In: American Economic Review 103.3, pp. 251-56.

Blöndal, Sveinbjörn and Stefano Scarpetta (1999). "The Retirement Decision in OECD Countries". In: OECD Economics Department Working Paper 202, Organisation for Economic Cooperation and Development, Paris. 
Blundell, Richard, Eric French, and Gemma Tetlow (2016). "Retirement Incentives and Labor Supply". In: 1, pp. 457-566.

Blundell, Richard and Thomas MaCurdy (1999). Labor Supply: A Review of Alternative Approaches. Vol. 3. Elsevier, pp. 1559-1695.

Börsch-Supan, Axel and Irene Ferrari (2017). "Old-Age Labor Force Participation in Germany: What Explains the Trend Reversal among Older Men? And What the Steady Increase among Women?" In: National Bureau of Economic Research Working Paper No. 24044.

Card, David, Jochen Kluve, and Andrea Weber (2010). "Active Labour Market Policy Evaluations: A Meta-Analysis". In: The Economic Journal 120.548.

Carrasco, Raquel, Juan F Jimeno, and A Carolina Ortega (2008). "The Effect of Immigration on the Labor Market Performance of Native-Born Workers: Some Evidence for Spain". In: Journal of Population Economics 21.3, pp. 627-648.

Case, Anne and Angus Deaton (2017). "Mortality and Morbidity in the 21st Century". In: Brookings Papers on Economic Activity.

Cattaneo, Cristina, Carlo V Fiorio, and Giovanni Peri (2015). "What Happens to the Careers of European Workers When Immigrants "Take Their Jobs"?" In: Journal of Human Resources 50.3, pp. 655-693.

CEA (2016). "The Long-Term Decline in Prime-Age Male Labor Force Participation". In: Council of Economic Advisers, Executive Office of the President of the United States.

Christiansen, Lone Engbo, Huidan Lin, Joana Pereira, Petia Topalova, and Rima Turk (2016). Gender Diversity in Senior Positions and Firm Performance. International Monetary Fund.

Cipollone, Angela, Eleonora Patacchini, Giovanna Vallanti, et al. (2013). "Women Labor Market Performance in Europe: Novel Evidence on Trends and Shaping Factors". In: IZA Discussion Papers 7710, IZA Institute of Labor Economics, Bonn, Germany.

Clements, Benedict J, Kamil Dybczak, Vitor Gaspar, Sanjeev Gupta, and Mauricio Soto (2015). "The Fiscal Consequences of Shrinking Populations". In: Staff Discussion Note, 15/21, International Monetary Fund.

Cortes, Guido Matias, Nir Jaimovich, and Henry E Siu (2018). "The "End of Men" and Rise of Women in the High-Skilled Labor Market". In: National Bureau of Economic Research Working Paper No. 24274.

D'Amuri, Francesco and Giovanni Peri (2014). "Immigration, Jobs, and Employment Protection: Evidence from Europe Before and During the Great Recession". In: Journal of the European Economic Association 12.2, pp. 432-464.

Dao, Mai Chi, Ms Mitali Das, Zsoka Koczan, and Weicheng Lian (2017). "Why Is Labor Receiving a Smaller Share of Global Income? Theory and Empirical Evidence". In: International Monetary Fund Working Paper 17/169.

Dao, Mai, Davide Furceri, Tae-Jeong Kim, Meeyeon Kim, and Jisoo Hwang (2014). "Strategies for Reforming Korea's Labor Market to Foster Growth". In: International Monetary Fund Working Paper 14/137.

De Resende, Carlos (2014). "An Assessment of IMF Medium-Term Forecasts of GDP Growth". In: IEO Background Paper No. BP/14/01 (Washington: Independent Evaluation Office of the IMF).

De Serres, Alain, Fabrice Murtin, and Christine De La Maisonneuve (2012). "Policies to Facilitate the Return to Work". In: Comparative Economic Studies 54.1, pp. 5-42.

Driscoll, John C and Aart C Kraay (1998). "Consistent Covariance Matrix Estimation with Spatially Dependent Panel Data". In: Review of Economics and Statistics 80.4, pp. 549-560.

Duval, Romain (2003). "The Retirement Effects of Old-Age Pension and Early Retirement Schemes in OECD Countries". In: OECD Economic Studies 2, pp. 7-50.

- (2004). "Retirement Behaviour in OECD Countries". In: OECD Economic Studies 2003.2, pp. $7-50$. 
Eberstadt, Nicholas (2016). Men Without Work: America's Invisible Crisis. Templeton Foundation Press.

Eliason, Marcus and Donald Storrie (2009). "Does Job Loss Shorten Life?" In: Journal of Human Resources 44.2, pp. 277-302.

Elsby, Michael WL, Bart Hobijn, and Ayşegül Şahin (2015). "On the Importance of the Participation Margin for Labor Market Fluctuations". In: Journal of Monetary Economics 72, pp. 6482.

Feingold, Alan (1994). "Gender Differences in Personality: A Meta-Analysis." In: Psychological bulletin 116.3 , p. 429.

Fernández, Raquel (2013). "Cultural Change as Learning: The Evolution of Female Labor Force Participation over a Century". In: American Economic Review 103.1, pp. 472-500.

Foged, Mette and Giovanni Peri (2016). "Immigrants' Effect on Native Workers: New analysis on Longitudinal Data". In: American Economic Journal: Applied Economics 8.2, pp. 1-34.

Gal, Peter and Adam Theising (2015). "The macroeconomic Impact of Policies on Labour Market Outcomes in OECD Countries: A Reassessment". In: OECD Economic Department Working Paper 1271, Organisation for Economic Co-operation and Development, Paris, France.

Galor, Oded and David N Weil (1996). "The Gender Gap, Fertility, and Growth". In: American Economic Review 86.3, pp. 374-387.

Genda, Yuji, Ayako Kondo, and Souichi Ohta (2010). "Long-Term Effects of a Recession at Labor Market Entry in Japan and the United States". In: Journal of Human Resources 45.1, pp. 157-196.

Genre, Veronique, Ramón Gómez-Salvador, and Ana Lamo (2005). "The Determinants of Labour Force Participation in the European Union". In: Labour Supply and Incentives to Work in Europe.

Genre, Véronique, Ramón Gómez Salvador, and Ana Lamo (2010). "European Women: Why Do (n’t) They Work?" In: Applied Economics 42.12, pp. 1499-1514.

Gerdtham, Ulf-G and Magnus Johannesson (2003). "A Note on the Effect of Unemployment on Mortality". In: Journal of Health Economics 22.3, pp. 505-518.

Goos, Maarten, Alan Manning, and Anna Salomons (2014). "Explaining job polarization: Routinebiased technological change and offshoring". In: American Economic Review 104.8, pp. 250926.

Grigoli, Francesco, Zsoka Koczan, and Petia Topalova (2018). "A Cohort-Based Analysis of Labor Force Participation for Advanced Economies". In: International Monetary Fund Working Paper 18/120.

Gruber, Jonathan and David Wise (2000). "Social security programs and retirement around the world". In: Research in Labor Economics. Emerald Group Publishing Limited, pp. 1-40.

Heckman, James J, Robert J LaLonde, and Jeffrey A Smith (1999). "The Economics and Econometrics of Active Labor Market Programs". In: Handbook of Labor Economics. Vol. 3. Elsevier, pp. 1865-2097.

Holzer, Harry J, Paul Offner, and Elaine Sorensen (2005). "Declining Employment among Young Black Less-Educated Men: The Role of Incarceration and Child Support". In: Journal of Policy Analysis and Management 24.2, pp. 329-350.

Hurd, Michael and Susann Rohwedder (2011). "Trends in Labor Force Participation: How Much is Due to Changes in Pensions?" In: Journal of Population Ageing 4.1-2, pp. 81-96.

IMF (2003). "Unemployment and Labor Market Institutions: Why Reforms Pay Off". In: World Economic Outlook, Chapter 4, International Monetary Fund.

- (2016a). "Spillovers from China's Transition and from Migration". In: World Economic Outlook, Chapter 4, April, International Monetary Fund.

- (2016b). "Time for a Supply-Side Boost? Macroeconomic Effects of Labor and Product Market Reforms in Advanced Economies". In: World Economic Outlook, Chapter 3, April, International Monetary Fund. 
IMF (2017a). "Recent Wage Dynamics in Advanced Economics: Drivers and Implications". In: World Economic Outlook, Chapter 2, October, International Monetary Fund.

- (2017b). "Understanding the Downward Trend in Labor Income Shares". In: World Economic Outlook, Chapter 3, April, International Monetary Fund.

- (2018). "Shifts in Global Manufacturing Activity". In: World Economic Outlook, Chapter 3, April, International Monetary Fund.

IMF/WB/WTO (2017). "Making Trade an Engine of 23 Growth for All: The Case for Trade and for Policies to Facilitate Adjustment". In: Policy Papers for Discussion at the Meeting of G20 Sherpas, March 23-24. Frankfurt, Germany.

Jaumotte, Florence (2003). "Female Labour Force Participation: Past Trends and Main Determinants in OECD Countries". In: OECD Economics Department Working Paper 376, Organisation for Economic Co-operation and Development, Paris.

Kahn, Lisa B (2010). "The Long-Term Labor Market Consequences of Graduating from College in a Bad Economy". In: Labour Economics 17.2, pp. 303-316.

Knabe, Andreas and Steffen Rätzel (2011). "Scarring or Scaring? The Psychological Impact of Past Unemployment and Future Unemployment Risk". In: Economica 78.310, pp. 283-293.

Koczan, Zsoka and Benjamin Hilgenstock (2018a). "Permanently displaced? Increasingly disconnected? Labor force participation in U.S. states and metropolitan areas". In: International Monetary Fund Working Paper (forthcoming).

- (2018b). "Still attached? Are social safety nets working? Labor force participation in European regions". In: International Monetary Fund Working Paper (forthcoming).

- (2018c). "Storm Clouds Ahead? Migration and Labor Force Participation Rates". In: International Monetary Fund Working Paper (forthcoming).

Krause, Eleanor and Isabel Sawhill (2017). "What We Know and Don't Know about Declining Labor Force Participation: A Review". In: Center on Children and Families at Brookings, The Brookings Institution, Washington, DC.

Krueger, Alan B (2017). "Where Have All the Workers Gone? An Inquiry into the Decline of the US Labor Force Participation Rate". In: Brookings Papers on Economic Activity, pp. 7-8.

Lucas, Richard E, Andrew E Clark, Yannis Georgellis, and Ed Diener (2004). "Unemployment Alters the Set Point for Life Satisfaction". In: Psychological Science 15.1, pp. 8-13.

Murtin, Fabrice, Alain De Serres, and Alexander Hijzen (2014). "Unemployment and the Coverage Extension of Collective Wage Agreements". In: European Economic Review 71, pp. 52-66.

Ngai, L Rachel and Barbara Petrongolo (2017). "Gender Gaps and the Rise of the Service Economy". In: American Economic Journal: Macroeconomics 9.4, pp. 1-44.

Nickell, Stephen (1981). "Biases in Dynamic Models with Fixed Effects". In: Econometrica, pp. 14171426 .

Olivetti, Claudia and Barbara Petrongolo (2017). "The Economic Consequences of Family Policies: Lessons from a Century of Legislation in High-Income Countries". In: Journal of Economic Perspectives 31.1, pp. 205-30.

Oreopoulos, Philip, Till Von Wachter, and Andrew Heisz (2012). "The Short- and Long-Term Career Effects of Graduating in a Recession". In: American Economic Journal: Applied Economics 4.1, pp. 1-29.

Pager, Devah, Bruce Western, and Naomi Sugie (2009). "Sequencing Disadvantage: Barriers to Employment Facing Young Black and White Men with Criminal Records". In: The ANNALS of the American Academy of Political and Social Science 623.1, pp. 195-213.

Rendall, Michelle (2010). "Brain versus Brawn: The Realization of Women's Comparative Advantage". In: IEW Working Papers 491, University of Zurich.

Schmitt, John and Kris Warner (2010). "The Changing Face of US Labor, 1983-2008". In: Journal of Labor and Society 13.2, pp. 263-279.

Soskice, David (1990). "Wage Determination: The Changing Role of Institutions in Advanced Industrialized Countries". In: Oxford Review of Economic Policy 6.4, pp. 36-61. 
Sullivan, Daniel and Till Von Wachter (2009). "Job Displacement and Mortality: An Analysis Using Administrative Data". In: The Quarterly Journal of Economics 124.3, pp. 1265-1306.

Thévenon, Olivier (2013). "Drivers of Female Labour Force Participation in the OECD". In: OECD Economics Department Working Paper 145, Organisation for Economic Co-operation and Development, Paris.

UN (2017). "The Impact of the Technological Revolution on Labour Markets and Income Distribution". In: Frontier Issues.

Winkelmann, Liliana and Rainer Winkelmann (1995). "Happiness and Unemployment: A Panel Data Analysis for Germany". In: Applied Economics Quarterly 41.4, pp. 293-307. 


\section{Appendix A. Sample}

The samples include the following countries:

Aggregate analysis: Australia, Austria, Belgium, Canada, Denmark, Finland, France, Germany, Greece, Italy, Ireland, Japan, Korea, Luxembourg, Netherlands, New Zealand, Norway, Portugal, Spain, Sweden, Switzerland, United Kingdom, United States.

Individual-level analysis: Austria, Belgium, Cyprus, Czech Republic, Denmark, Germany, Estonia, Finland, France, Greece, Iceland, Ireland, Italy, Latvia, Lithuania, Netherlands, Norway, Portugal, Slovakia, Slovenia, Spain, Sweden, Switzerland, United Kingdom. 


\section{Appendix B. Variable Construction and Sources}

In the following, we report how we construct the variables entering the regression analysis and the original data sources:

- Aggregate and group-specific labor force participation rates are expressed as a share of the relevant population group. Sources: OECD, Employment database; Eurostat; National authorities, Barro-Lee Educational Attainment dataset.

- The cyclical position is captured with the output gap, while robustness tests use the unemployment rate. Source: IMF, World Economic Outlook database.

- Exposure to technological progress is measured as the interaction between the cross-country average relative price of investment and the country's exposure to routinization through its initial occupational mix. The latter consists of scores that rely on occupation-level measures, which order occupations by their share of routine tasks, and then use the employment shares of these occupations to construct country-level measures of routinizability. ${ }^{33}$ Sources: IMF, World Economic Outlook database, Autor and Dorn (2013), Eurostat, and Population censuses.

- Trade openness is measured as the sum of exports and imports in percent of GDP. Source: IMF, World Economic Outlook database.

- Potential shifts in the demand for different types of labor due to structural transformation are measured as the ratio of employment in the services sector relative to employment in the industrial sector. Sources: World Bank, World Development Indicators; European Union, Level analysis of Capital, Labour, Energy, Materials, and Service inputs. The share of urban population is also used. Sources: World Bank, World Development Indicators.

- Educational attainment is measured as the share of the population within a specific agegender group with highest level of education reported as primary, secondary, or tertiary. Source: Barro-Lee Educational Attainment dataset.

- The labor tax wedge is defined as the ratio between the average tax paid by a single-earner family (one parent at 100 percent of average earnings with two children) and the corresponding total labor cost for the employer. The labor tax wedge is available from the OECD for 2000 to 2016, and was extended back to 1980 using Bassanini and Duval (2006) and IMF (2016b). The latter series is available only in uneven years; the value of the labor tax wedge in even years is obtained by linear interpolation. Sources: OECD, Tax database; Bassanini and Duval (2006); IMF (2016b).

- The generosity of the unemployment benefits system is measured as the gross replacement rate, gross unemployment benefit levels as a percentage of previous gross earnings. The summary measure with the best coverage is the average of the gross unemployment benefit replacement rates for two earnings levels, three family situations, and three durations of unemployment. Such measures are available in uneven years, and are interpolated to obtain their values for even years. The reported values are for the average worker from 2001 to 2011, and average production worker from 1961 to 2005. The two series are spliced. Source: OECD, Benefits and Wages: Statistics.

\footnotetext{
${ }^{33}$ The cross-country average relative price of investment across all AEs is used to minimize endogeneity concerns and capture changes that are due to global technological progress (rather than, for example, country-specific capital taxation policies).
} 
- Public expenditure on active labor market programs is calculated as active labor market programs spending per unemployed person in percent of GDP per capita, following Gal and Theising (2015). Source: OECD, Employment database.

- Restrictiveness of migration policy is an index with information about all changes to the existing legal framework relevant for migration (see also De Resende, 2014). We focus on major changes in policies guiding the post-entry rights or other aspects of migrants' integration. These changes are cumulated starting 1980 to construct an index for each country, with a higher value denoting more restrictive policies. Source: International Migration Institute, DEMIG POLICY database.

- Union density is measured as net union membership as a proportion of wage earners in employment. Source: OECD, Employment database.

- Coordination of wage setting is an index of the centralization of bargaining. The index runs from 1 to 5 with values defined as (1) Fragmented wage bargaining, confined largely to individual firms or plants, (2) mixed industry and firm-level bargaining, weak government coordination through minimum wage setting or wage indexation, (3) negotiation guidelines based on centralized bargaining, (4) wage norms based on centralized bargaining by peak association with or without government involvement, and (5) maximum or minimum wage rates/increases based on centralized bargaining. Source: Amsterdam Institute for Advanced Labour Studies, Database on Institutional Characteristics of Trade Unions, Wage Setting, State Intervention, and Social Pacts.

- Policies that help reconcile work inside and outside the household are proxied by public spending on childcare and education as a percent of GDP; the proportion of employees with a part-time contract to total employees; and job-protected maternity leave, defined as the total number of weeks of job-protected maternity, parental, and extended leave available to mothers, regardless of income support. Sources: OECD, Social protection database; OECD, Employment database; OECD, Family database.

- Retirement incentives are proxied by the statutory retirement age and by the generosity of pension schemes. Several alternatives are used to capture the generosity of pension schemes. The measure with the best country and time coverage is old-age and incapacity spending as a percent of GDP. This measure is first purged from fluctuations due to cyclical and demographic factors (namely, share of the population in different age groups and health status, proxied by life expectancy) that may mechanically generate a negative correlation with the labor force attachment of older workers. As a robustness check, the analysis considers the (conceptually more appropriate but less widely available) implicit tax on continued work, calculated as the change in the present value of the stream of future pension payments net of contributions to the system from working five more years for typical workers at different ages. An alternative measure also considered is the aggregate replacement ratio, calculated as the ratio of the mean disposable income of ages 65-74 to the mean disposable income of ages 50-59. This variable is computed for select years based on the availability of household survey data and is interpolated for the missing years. Sources: Social Security Programs throughout the World; OECD, Social protection database; Duval (2003); IMF (2016b); Luxembourg Income Study database. 